(2) conselho nacional de desenVolvimento cientifico e teCnologico (CNPq.) INSTITUTO NACIONAL DE PESQUISAS DA AMAZÔNIA (INPA)

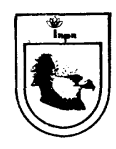

\title{
Oligochaeta (Annelida) do Instituto Nacional de Pesquisas da Amazônia
}

\author{
Gilberto Righi \\ Universidade de Sáo Paulo \\ lone Ayres \\ Instituto Nacional de \\ Pesquisas da Amazônia \\ Elizabeth C. R. Bittencourt \\ Universidade de Säo Paulo
}

ACTA AMAZONICA Vol. 8(3): Suplemento 1

Manaus-Amazonas 
RIGHI, Gilberto

Oligochaeta (Annelida) do Instituto Nacional de Pesquisas da. Amazônia.

Acta Amazonica, Manaus, 8(3) : Suplemento (1), set. 1978. 49 p.

Colaboração de: Ione Ayres \& Elizabeth C. R. Bittencourt.

III. Título.

1. Oligochaeta 2. Zoogeografia I. Ayres, lone II. Bittencourt, E. C. R.

CDD 595.146

CDU 595.14

591.9811

$591.9(811.3)$

RESUMO: Da Amazônia brasileira foram estudadias anatomo-sistematicamente 25 espécies de Oligochaeta distribuídas em 16 gêneros e 8 famílias como segue: Haplotaxidae: Tiguassu reginae, gen. $n_{.}$, sp. $n_{\text {.; }}$ Enchytraeidae: Marionina patua, sp. n.; Alluroididae: Brinkhurstia americanus (Brinkhurst, 1964); Glossoscolecidae: Atatina gatesi, sp. n., Amazo atroaris sp. n.,

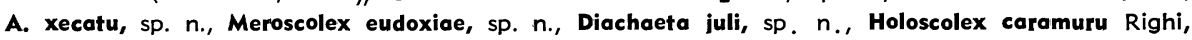
1975, H. nemorosus tacoa, subsp. n., Glossodrilus (G.) schubarti, sp. n.; Sparganophilidae?: Areco reco, gen. n., sp. n.; Ocnerodrilidae: Eukerria guamais Righi, 1971, Haplodrilus (H.) tagua, sp. r.., Dariodrilus ferrarius, gen. $n_{\text {., sp. }}$., Exisdrilus rarus, gen. n., sp. n.; Acanthodrilidae : Wegeneriella divergens itapecu, subsp. $n ., w$. tocaya, sp. $n$;; Octachaetidae: Dichogaster affinis (Michaelsen, 1890), D. bolaui bolaui (Michaelsen, 1891), D. modigliani (Rosa, 1896), D. saliens (Beddard, 1892), D andina evae, subsp. n., D. ibaia, sp. n., D. badajos, sp. n.

ABSTRACT: From the Brazilian Amazonia 25 species of Oligochaeta were studied for their anatomy and systematics. They are distributed onto 16 genera and 8 families as follows. Haplotaxidae: Tiguassu reginae gen. n., sp. n.; Enchytraeidae: Marionina patua sp. n.; Alluroididae: Brinkhurstia americanus (Brinkhurst, 1964); Glosos-colecidae: Atatina gatesi, sp. n., Amazo atroaris, sp. n.; A. xecatu, sp. n., Meroscolex eudoxiae, sp. n.; Diacheta juli, sp. n., Holoscolex caramuru Righi, 1975, H. nemorosus tacoa, subsp. n., Glossodrilus (G.) schubarti, sp. n.; Sparganophilidae: Areco reco, gen. $n_{\text {., sp. }}$.; Ocnerodrilidae: Eukerria guamais Righi, 1971, Haplodrilus (Hi) tagua, sp. n., Dariodrilus ferrarius, gen. n., sp. n., Exisdrilus rarus, gen. n., sp. n.; Acanthodrilidae: Wegeneriella divergens itapecu, subsp. n.; Wi. tocaya, sp. n.; Octochaetidae: Dichogaster affinis (Michaelsen, 1890), D. bolaui bolaui (Michaelsen, 1891), D. modigliani (Rosa, 1896), D. saliens (Beddard, 1892), D. andina evae, subsp. n., D. ibaia, sp. n., D. badajos, sp. $n$. 


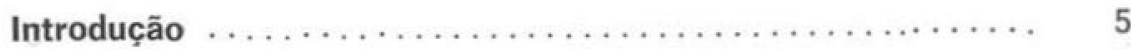

Agradecimentos ....................... 5

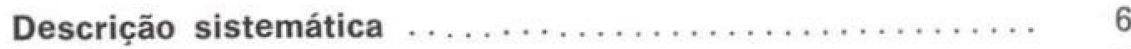

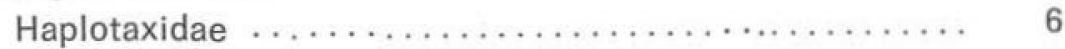

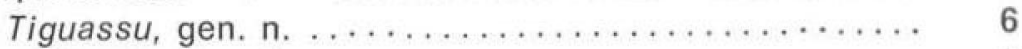

Tiguassu reginae, $\mathrm{sp} . \mathrm{n} . \ldots \ldots \ldots \ldots \ldots \ldots \ldots \ldots$

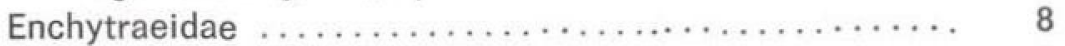

Marionina patua, $\mathrm{sp} . \mathrm{n} . \ldots \ldots \ldots \ldots \ldots \ldots \ldots . \ldots \ldots$

Alluroididae ................................ 11

Brinkhurstia americanus (Brinkhurst, 1964) ...... 11

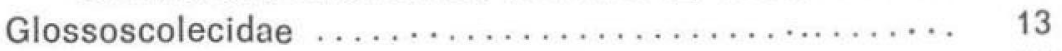

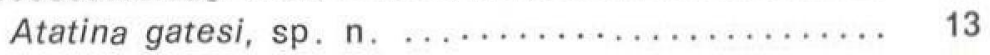

Amazo Righi et al., $1976 \ldots \ldots \ldots \ldots \ldots \ldots \ldots \ldots$

Amazo atroaris, $\mathrm{sp} . \mathrm{n} . \ldots \ldots \ldots \ldots \ldots \ldots \ldots . \ldots \ldots$

Amazo xecatu, sp $\mathrm{n} . \ldots \ldots \ldots \ldots \ldots \ldots \ldots . \ldots . \ldots . \ldots . \ldots$

Meroscolex eudoxiae, sp. n. ............ 17

Diachaeta juli, sp. n. .................. 18

Holoscolex caramuru Righi, $1975 \ldots \ldots \ldots \ldots \ldots . . .21$

Holoscolex nemorosus tacoa, subsp. n. ........ 21

Glossodrilus (G) schubarti, sp. n. .......... 22

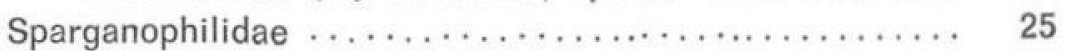

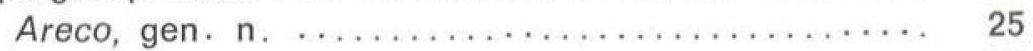

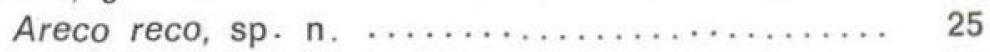

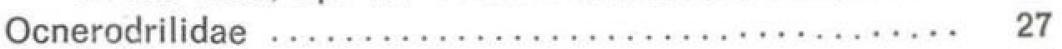

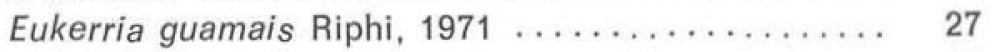

Haplodrilus Eisen, $1900 \ldots \ldots \ldots \ldots \ldots \ldots \ldots . \ldots \ldots$

Haplodrilus (H.) tagua, sp. n. ............. 28

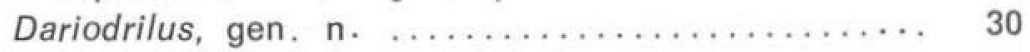

Dariodrilus ferrarius, $\mathrm{sp} . \mathrm{n} . \ldots \ldots \ldots \ldots \ldots \ldots . . . . .6$

Exisdrilus, gen. $\mathrm{n} . \ldots \ldots \ldots \ldots \ldots \ldots \ldots \ldots \ldots \ldots \ldots$

Exisdrillus rarus, $\mathrm{sp}, \mathrm{n} . \ldots \ldots \ldots \ldots \ldots \ldots \ldots . . \ldots \ldots$

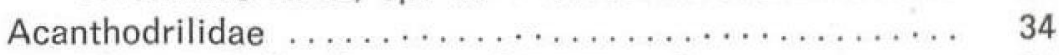

Wegeneriella divergens itapecu, subsp. n. ..... 34

Wegeneriella tocaya, sp. n. ............. 36

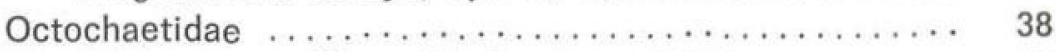

Dichogaster affinis (Michaelsen, 1890) ......... 38

Dichogaster bolaui bolaui (Michaelsen, 1891) .... 38

Dichogaster modigliani (Rosa, 1896) ......... 38

Dichogaster saliens (Beddard, 1892) .......... 39

Dichogaster andina evae, subsp. n. ......... 39

Dichogaster ibaia, sp. n. ................ 42

Dichogaster badajos, sp. n. ............. 44

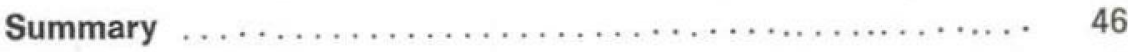

Bibliografia citada $\ldots \ldots \ldots \ldots \ldots \ldots \ldots \ldots \ldots \ldots \ldots$ 
F. S. Leuckart registrou em 1835 , pela primeira vez, a presença de vermes oligoquetos no continente sul americano. Não obstante terem decorridos mais de 150 anos, o saldo atual dos conhecimentos desta importante ordem zoológica, em nosso continente e principalmente na região amazônica, é fragmentário e cheio de lacunas múltiplas. Este estágio só pode ser ultrapassado com uma exploração intensa de novos materiais de diversas procedências .

Com esse intuito, em junho de 1975, um de nós (G. Righi) coletou nas reservas florestais do Instituto Nacional de Pesquisas da Amazônia e na região de Sucunduri (Estrada Transamazônica). Esta coleção foi enriquecida por exemplares obtidos anteriormente por I. Ayres. Deste modo, pudemos reunir 38 espécies de Oligochaeta da Amazônia brasileira, das quais 13 espécies de Glossoscolecidae foram tratadas por nós em publicação anterior nesta mesma revista. As restantes 25 espécies são agora apresentadas.

Os estudos que se seguem foram baseados em animais fixados em formalina $10 \%$, dissecados, em preparações totais coradas pelo Paracarmim de Mayer e em cortes seriados corados pelo método tríplice de Mallory. Os sintipos estão depositados no Instituto Nacional de Pesquisas da Amazônia (INPA), Manaus.

\section{AGRADECIMENTOS}

Nós somos especialmente gratos ao Engenheiro Jurandir de Alencar, da Reserva Florestal Ducke, pela sempre pronta cedência de seu técnico Evaristo F. do Nascimento para auxiliar-nos em nossas coletas.

Nossa coleção de Oligoquetas da Amazônia foi obtida graças a valiosa colaboração deste amigo e ao inestimável trabalho do $\mathrm{Sr}$. Evaristo F. do Nascimento.

Agradecemos também aos colegas e amigos que em suas viagens coletaram animais para nós, assim enriquecendo nossa coleção. 


\section{DESCRIÇÃO SISTEMÁTICA}

\section{HAPLOTAXIDAE}

Tiguassu, gen, $n$.

DIAGNOSE

Quatro pares de cerdas sigmóides e intimamente geminadas por segmento. Holonefrídios pares em alguns segmentos prégonadais e em todos os segmentos posgonadais. Três moelas musculosas fundidas entre si, nos segmentos VI - VIII. Glândulas septais presentes até em IX. Par de corações laterais musculosos em X. Testículos em XI. Funis seminais em $X$ (reduzidos) e em XI (funcionais). Dutos seminais curtos e pouco ondulados em XI e XII, sem átrio e sem glândulas associadas. Poros masculinos laterais no equador de XI (reduzidos) e no de XII (funcionais). Vesículas seminais longas, nastriformes. Ovários e funis ovulares em XII. Ovidutos curtos. Poros femininos laterais, no equador de XIII. Espematecas simples, sem divertículos, anteriores às gônadias.

\section{TIPO DO GÊNERO}

Tiguassu reginae, $\mathrm{sp} . \mathrm{n}$.

\section{CONSIDERAÇṌES}

Em revisões recentes, Brinkhurst (1966: 33; 1971: 286) reuniu os gêneros Pelodrilus Beddard, 1891, Heterochaetella Yamaguchi, 1953 e Adenodrilus Cekanovskaya, 1959 no gênero único Haplotaxis pela posse de três moelas esofágicas e pela posição dos testículos. Pelodrilus (?) falcifer Omodeo, 1958, conhecido da África, Monte Nimba, apresenta, como Tiguassu reginae, um único par de testículos em XI, diferindo pela falta de moela e pela posição dos ovários em XIII.

$\mathrm{O}$ nome do novo gênero deriva da língua tupi, onde "ti" = nariz e "guassu" $=$ grande.
Tiguassu reginae, sp. $\mathrm{n}$.

(Fig. 1-4)

\section{MATERIAL}

Brasil, Amazonas : estrada Manaus-Rio Branco, $\mathrm{Km}$ 45 (Reserva Biológica da Campina), em tronco podre, junto a um igarapé; 2 exemplares clitelados e 1 aclitelado (INPAZ-80), L. Antony \& G. Richi col, 25/6/1975.

Em um dos exemplares maduros, o clitelo está bem diferenciado e tem forma anelar nos segmentos XIII - XVIII $(=6)$. No outro exemplar o clitelo, em início de diferenciação, só é reconhecível em cortes, nos segmentos XIII. XVII. Na descrição abaixo estes animais serão designados por $\mathrm{A}$ e $\mathrm{B}$, respectivamente. O comprimento dos dois animais maduros é de $33 \mathrm{~mm}$ e o diâmetro, na região mediana do corpo, é de $1 \mathrm{~mm}$. Pigmento ausente. Em cada segmento há uma delgada faixa circular, equatorial, de cor branca leitosa, onde se implantam as cerdas. O número de segmentos de $A$ é 112; os últimos 16 são especialmente curtos, apresentando-se como um regenerado recente. $O$ animal B tem 132 segmentos. Os sulcos intersegmentares são aprofundados na região anterior, de modo que os segmentos são facilmente reconhecíveis até o XII ou XIII. Para trás, os intersegmentos são mal definidos e os segmentos reconheciveis apenas pela faixa equatorial branca e pelas cerdas. O prostômio (Fig. 1) é tentaculiforme, tão longo quanto os 5 ou 6 segmentos anteriores e nos três exemplares apresenta-se dobrado em cotovelo. Sua porção basal é larga, bilobada e dirigida para a frente. A porção distal, dirigida para cima é mais longa e adelgaça-se em direção à ponta; seus $3 / 4$ proximais são percorridos por numerosos sulcos anelares.

As cerdas dispõem-se em 4 pares de séries longitudinais a partir de II. São sigmóides, alongadas e com um pequeno nódulo submediano (Fig. 2). O comprimento das cerdas ventrais e laterais é semelhante e, na regiăo mediana do corpo, varia de $80-90 \mu \mathrm{m}$. A re- 
lação entre as cerdas nos segmentos XXXV $\mathrm{XL}$ de $\mathrm{A}$ e $\mathrm{B}$ é respectivamente $a a: a b: b c$ : $c d: d d=12,33: 1,00: 12,33: 0.83: 37,33=$ $15,16: 1,00: 13,50: 0,83: 47,33$. A espessura da parede do corpo é ao redor de $75 \mu \mathrm{m}$ dado especialmente o grande desenvolvimento da musculatura longitudinal. A musculatura circular é bem diferenciada nos segmentos anteriores, tornando-se mais fina em direção ao clitelo. Na região mediana dos segmentos posclitelares, esta camada muscular atinge em média $3 \mu \mathrm{m}$ de espessura, sendo mais fina do que o epitélio, cuja espessura média é de 6 $\mu \mathrm{m}$. Daí, o não reconhecimento dos intersegmentos em vista superficial. Linha lateral ausente.

Em $A$ e $B$, encontram-se duas volumosas papilas pubertais crateriformes e assimétricas, dispostas em linha com as cerdas ventrais. A papila anterior situa-se à esquerda em IX e a posterior à direita em XIV. Cada papila corresponcie a um volumoso grupo de células glandulares que ficam mergulhadas na parede do sorpo. Um par de traves pubertais pouco salientes estende-se, no exemplar $A$, em $1 / 2$ $b c$ de $1 / 2 \mathrm{XI}-\mathbf{i} / 2 \mathrm{XiV}$ do lado esquerdo e de XII - XIII do lado direito. Em B as traves são simétricas e situam-se em $1 / 2$ bc de XII - XIII. Os poros genitáis são reconhecíveis apenas em cortes.

Os septos ocorrem a partir cie 4/5 (Fig. 3) . Os $8 / 9-12 / 13$ são pouco mais espessos do que os demais; todos têm disposição transversal. A faringe (Fig. 3, F) forma um divertículo dorsal amplo e largarnente aberto, preso à parede do corpo por numerosas faixas musculares intercruzantes. O teto do divertículo é formado por uma larga placa de células cilíndricas, altas. Enire as faixas musculares, encontram-se alguns pequenos e esparsos conjuntos de células glaiidulares, cuja conexão com a placa faríngea não foi possivel estabelecer. Pares de largas massas de células glandulares, irregularmente lobuladas, (GS) encontram-se nos segmentos V, VI, VIII e IX. Estas glandu'as são ricamente vascularizadas e presas à parede do corpo por faixas conjuntivomusculares; em alguns pontos, aderem-se aos septos. As glândulas de cada lado continuam por uma larga faixa que corre látero-ventralmente ao esôfago e à moela, terminando na placa faríngea. O par de faixas é, provavelmente, formado pelos prolongamentos das células glandulares. Estas glânduias assemelhamse às chamadas glândulas septais das Enchytraeidae. A faringe segue-se um curto e delgado esôfago, que se dilata em uma volumosa moela (M), de espessa parede muscular, sem glândulas associadas e com forte revestimento cuticular. A moela é cilíndrica nos segmentos VI - VIII, com ligeiras constrições na altura dos septos $6 / 7$ e $7 / 8$, representando a fusão de 3 moeias sucessivas. O esôfago dilata-se em IX e $X$, onde atinge diâmetro pouco maior do que o da moela. Adelgaça-se abruptamente em $\mathrm{XI}$, apresentando em XI e XII um diâmetro de aproximadamente metade do da moela. A transição esôfago intestino situa-se em 12/13. O intestino (I) dilata-se bruscamente em XIII e em XIV já tem o diâmetro normal posterior. Estruturas calciferas, apêndices e tiflosole ausente. Exceto a faringe, esôfago anterior e moela, o restante do tubo digestivo está repleto de restos vegetais.

O aparelho excretor compõem-se de pares de holonefrídios nos segmentos IX, X e de XIV para trás. Faltam nefrídios nos segmentos VIII e anteriores, bem como nos XI - XIII. Em cada nefrídio, o nefróstoma compõem-se de um lábio inferior pequeno e de um lábio superior largo, formado por numerosas células altas e ciliadas (Fig. 4). No pescoço, há um conjunto de células peritoniais. O corpo dos nefrídios compõem-se de um complexo enovelado de canalículos envolvendo parcialmente um duto mediano, largo, com a parede totalmente revestida por fina granulação. O diâmetro médio dos canalículos é de $2,5 \mu \mathrm{m}$ e o do duto mediano $7,5 \mu \mathrm{m}$. Bexiga e ampola não foram reconhecidas. O peritônio, junto aos nefrídios, é formado por largas células mais ou menos retangulares, medindo em média $50 \times 25 \mu \mathrm{m}$. Infelizmente, os dois animais microtomizados não ficaram bons para estudos do aparelho circulatório. Além dos vasos dorsal e ventral, foi possivel reconhecer apenas um volumoso par de corações laterais de parede musculosa, no segmento $X$. 
Um par de testículos volumosos situa-se no segmento XI (Fig. 3, T), cuja cavidade, no animal $B$, está repleta de espermatozóides em diferenciação. Duas longas vesículas seminais (VS) nastriformes estendem-se dos lados do intestino até o segmento XXIII ou XXV de B. Em $A$, a cavidade de XI contém poucos espermatozóides e as vesículas seminais estão em redução; encontram-se vazias em XII - XIII. O par de funis seminais de XI (FS2) são largos e pregueados. Continuam-se pelos dois dutos seminais que formam algumas alças os lados do intestino em XII, abrindo-se ảiretamente na superfície no equador deste segmento, na metade dcrsal de $b c$. O diâmetro externo dos dutos seminais é de $32 \mu \mathrm{m}$ e o interno de $9 \mu \mathrm{m}$; sua parede é formada por células cilíndricas, altas e ciliadas. Em X, não há testículos, porém há um par de pequenos funis seminais (FSI)). Seus dutos formam poucas alças em $\mathrm{XI}$, abrindo-se no equador do segmento, na mesma linha dos poros de XII. Os dutos seminais de $X I$ são pouco mais delgados do que os de XII e apresentam-se obliterados em alguns pontos. Seu diâmetro externo é de 23 $\mu \mathrm{m}$ e o interno de $4 \mu \mathrm{m}$, em média. Não há átrio nem glândulas associadas aos dutos seminais. Os testículos de XI prendem-se, em parte, no septo $10 / 11$ e principalmente na porção basal dos dutos seminais que partem de $\mathrm{X}$.

Um par de ovários (O) encontra-se em XII aderido à porção basal dos dutos seminais, que os atravessam em parte. Os ovários têm a forma geral de um cone, com algumas fileiras de ovos em diferenciação. Os ovos maduros, ricos em vitelo, têm um diâmetro variável de $40-50 \mu \mathrm{m}$. O largo par de funis ovulares (FO) continua-se por dois ovidutos pouco sinuosos, que se abrem no equador de XIII, na metade ventral de $b c$. Ovisacos não foram encontrados. Dois pares de espermatecas (E) localizam-se em IX e X, abrindo-se em $8 / 9$ e $9 / 10$ em série com có. As espermatecas são piriformes, sem distinção entre duto e ampola e as do segundo par são pouco maiores. Não foram encontradios espermatozóides no interior das espermatecas.

O nome" da nova espécie foi dado em homenagem à Srta. Regina Lucia de Lima Lopes pela sua valiosa colaboração.

\section{ENCHYTRAEIDAE}

Marionina patua, $\mathrm{sp} . \mathrm{n}$.

(Fig. 5 - 10)

\section{MATERIAL}

Brasil, Amazonas : Manaus, terreno do Instituto $\mathrm{Na-}$ cional de Pesquisas da Amazônia, 1 exemplar clitelado (INPAZ-86), G. Righi col. 19/6/1975.

O animal mede $9 \mathrm{~mm}$ de comprimento; o diâmetro é de $360 \mu \mathrm{m}$ na região anterior, 300 $\mu \mathrm{m}$ no clitelo e $340 \mu \mathrm{m}$ na região mediana do corpo. Apresenta 48 segmentos. O poro cefálico (Fig. 5, P) localiza-se na região mediana dorsal do prostômio. O clitelo ocupa os segmentos XII - 1/2 XIII. Suas células glandulares são pouco volumosas, dispostas irregularmente e faltam na região ventral. As cerdas são retas (Fig. 6), sem nódulo, com a extremidade proximal ligeiramente curva e a distal em ponta simples. Ocorrem 4 tufos de 2 cerdas cada, por segmento a partir de III. Faltam cerdas em XII. Na região preclitelar as cerdas laterais nedem, em média, $36 \mu \mathrm{m}$ de comprimento $\mathrm{e}$ as ventrais $38 \mu \mathrm{m}$. Na regiáo posclitelar, as cercias laterais medem, em média, $48 \mu \mathrm{m}$ e as ventrais $73 \mu \mathrm{m}$.

O esôfago passa gradualmente ao intestino. Não ocorrem divertículos em quaisquer pontos do tubo digestivo. Células cloragógenas são vistas a partir do segmento VI. Peptonefrídios faltam. As glândulas septais (Fig. 5, GSP) aparecem associadas aos septos $4 / 5$, $5 / 6$ e $6 / 7$, unindo-se as simétricas por uma faixa glandular acima do vaso dorsal. As glândulas do primeiro par não apresentam lobo ventral desenvolvido, ao contrário das do segundo e terceiro pares. Glândulas septais secundárias (GSS), de posição ventro-lateral, ocorrem associadas às primárias do primeiro e segundo pares. A drenagem da secreção destas glândulas é feita através de faixas que saem ventralmente de cada par e unem-se em uma faixa única de cada lado, que se dirige para a região dorsal da faringe $(F)$. $O$ gânglio cerebróide (Fig. 5, C; 7) é ovalado, medindo 162 por $106 \mu \mathrm{m}$ nas maiores dimensões. A face anterior é incisada e a posterior convexa. O vaso dorsal inicia-se no segmento XV. Os celomócitios são discóides e nucleados, apresentando em média $26 \mu \mathrm{m}$ de diâmetro. 

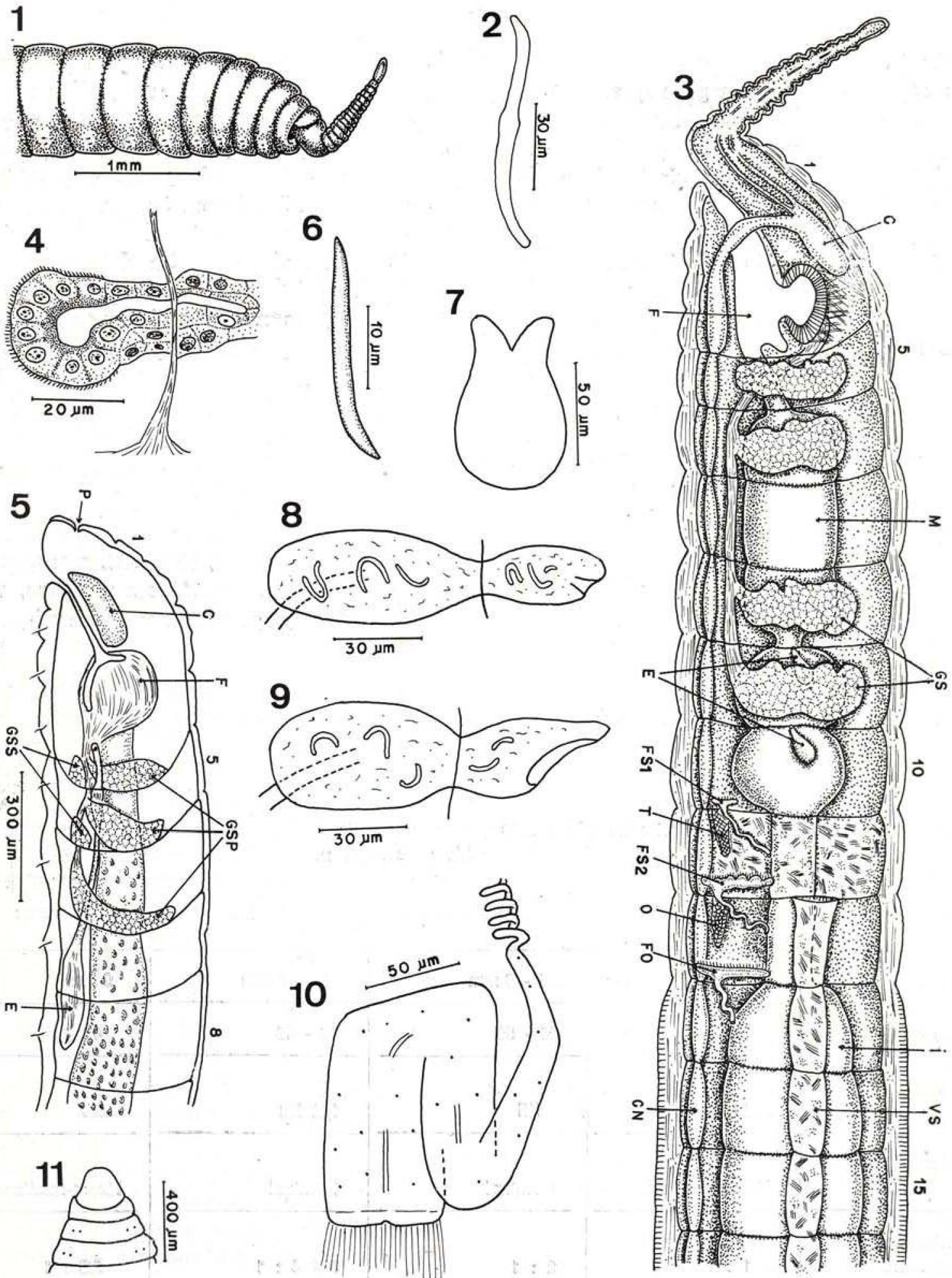

ESTAMPA I - Tiguassu reginae, gen. n., sp. n.: 1 - extremidade anterior em vista lateral; 2 - cerda da regiẫo mediana do corpo; 3 - reconstrução dos 14 primei.os segmentos baseada em cortes seriados; 4 - parte do septo 14/15 e funil nefridial. Marionina patua, sp. n.: 5 - corte óptico dos 8 primeiros segmentos; $6-$ cerda posclitelar; 7 - gânglio cerebróide; 8 - nefrídio de $6 / 7 ; 9$ - nefrídio de $30 / 31 ; 10$ - funil seminal. Brinkhurstia americanus. (Brinkhurst, 1964): 11 - extremidade anterior em vista dorsal. (C = gânglio cerebróide; $\mathrm{CN}=$ cordão nervoso; $\mathrm{E}=$ espermateca; $\mathrm{F}=$ faringe; $\mathrm{FS} 1=$ funil seminal $1 ; \quad F S 2=$ funil seminal $2 ; \quad F O=$ funil ovular; $\mathrm{GS}=$ glândulas septais; $\mathrm{GSP}=$ glândulas septais primárias; $\mathrm{GSS}=$ glândulas septais secundárias; $\mathrm{I}=$ intestino; $\mathrm{M}=$ moela; $\mathrm{O}=$ ovário; $\mathrm{P}=$ poro cefálico; $\mathrm{T}$ = testículo; $\mathrm{VS}$ = vesícula seminal.) 
O primeiro par de nefrídios (Fig. 8) prende-se ao septo 6/7. A parte pré-septal abrange o iunil e algumas voltas do canal nefridial; seu comprimento equivale a três quintos do da posseptal. Esta, de aspecto cilindróide, tem as voltas do canal nefridial mais numerosas. A região do nefrídio qua ctravessa o septo é $\mathrm{l}$ geiramente acinturada. Os nefrídios da região posclitelar (Fig. 9) têm a porção pré-septal equivalendo a dois terços da posseptal. Em todos os nefrídios, o duto excretor parte da face voltada para o intestino, na região mediana da porção posseptal. Um par de espermatecas livres atinge o segmento XIII (Fig. 5, E). Em cada espermateca a ampola é ovóide, sem divertículos, mede 97 por $54 \mu \mathrm{m}$ e localiza-se $\mathrm{cm} 3 / 4$ VII - VIII. O duto ectal mede $456 \mu \mathrm{m}$ de comprimento total; no segmento $\mathrm{V}$ apresenta umá dilatação de forma oval. Sua abertura iocaliza-se na região posterior de IV, próximo co intersegmento $4 / 5$. Faltam giândulas no duto. Ovários parciais (Teilovaria) localizamse nos segmentos XI e XII, medindo em média $74 \mu \mathrm{m}$ de diâmetro. Ovos maduros, com o plasma cheio de vitelo, atingem $322 \mu \mathrm{m}$ de comprimento e ocupam o espaço dos segmentos XI - XIV. Os testículos situam-se em XI, presos ao septo 10/11. Cada funil seminal (Fig. 10) é longo, adelgaçando-se para trás e apresenta-se dobrado em S; seu comprimento é de calculadamente $332 \mu \mathrm{m}$ e o maior diâmetro $60 \mu \mathrm{m}$ na abertura. Os dutos deferentes te:n a forma de uma espiral apertada; restringem-se ao s€gmento XII e abrem-se diretamente ao exterior, sem bulbo penial evidente.

\section{Considerações :}

Por ter as espermatecas livres dơ esôfagu e 2 cerdas por tufo ao longo de todo o corpo, Marionina patua, sp. n. aproxima-se de $M$. elgonensis (Cernosvitov, 1938), M. mesopsamma Lassere, 1964, 1966 e M. istriae Giere, 1974. As 4 espécies podem ser separadas pela Tabela 1.

O nome da nova espécie procede da língua tupi, onde "patua" = arca, caixa

TABELA 1 - Comparação entre Marionina elgonensis (Cernosvitov, 1938), M. mesopsamma Lassere, 1894, M. istriae Giere, 1974 e M. patua, sp. n.

\begin{tabular}{|c|c|c|c|c|}
\hline Marionina & elgonensis & mesopsamma & istriae & patua \\
\hline Comprimento & $1,4 \mathrm{~mm}$ & $5-6 \mathrm{~mm}$ & $7-10 \mathrm{~mm}$ & $9 \mathrm{~mm}$ \\
\hline Segmentos & 21 & $34-56$ & $38-43$ & 48 \\
\hline $\begin{array}{l}\text { Início do vaso } \\
\text { dorsal }\end{array}$ & após 12/13 & XII & $1 / 2 X I I$ & XV \\
\hline $\begin{array}{l}\text { Saída do canal } \\
\text { excretor }\end{array}$ & látero-mediana & terminal & terminal & látero-mediana \\
\hline $\begin{array}{l}\text { Funil seminal, compri- } \\
\text { mento : diâmetro }\end{array}$ & $1: 1$ & $2: 1$ & 3 a $4: 1$ & $5.5: 1$ \\
\hline $\begin{array}{l}\text { Glândulas no duto } \\
\text { ectal da espermateca }\end{array}$ & $\begin{array}{l}\text { totalmente } \\
\text { revestido }\end{array}$ & faltam & $\begin{array}{l}\text { revestidos os } \\
2 / 3 \text { ectais }\end{array}$ & faltam \\
\hline Habitat & lacustre & $\begin{array}{l}\text { marinho, } \\
\text { supra-litoral }\end{array}$ & $\begin{array}{l}\text { marinho } \\
\text { supra-litoral }\end{array}$ & terrestre \\
\hline Ocorrência . & $\begin{array}{l}\text { Africa Central, } \\
\text { Monte Elgon }\end{array}$ & $\begin{array}{l}\text { França, Baía } \\
\text { de Arcachon }\end{array}$ & $\begin{array}{l}\text { luguslávia, Mar } \\
\text { Adriático }\end{array}$ & $\begin{array}{l}\text { Brasil, Ama- } \\
\text { zonas }\end{array}$ \\
\hline
\end{tabular}




\section{ALLUROIDIDAE}

Brinkhurstia americanus (Brinkhurst, 1964)

(Fig. 11-21)

Alluroides americanus Brinkhurst, $1964: 553$, figs, 5-7. Brinkhurstia americanus, Jamieson, 1968 : 80, figs, 9 e 12; $1971: 716$, fig. 14.1E.

\section{MATERIAL}

Brasil, Amazonas : Sucunduri, em barranco junto ao Igarapé Saibroso, 8 exemplares clitelados e 1 jovem (INPAZ-89), E. Rufino col. 26/6/1975. Estrada Transamazônica, trecho Humaitá-Jacaréacanga, $\mathrm{Km} \mathrm{523,} \mathrm{em}$ tronco pobre junto a um igarapé, 1 exemplar clitelado (INPAZ-90), L. Antony col. 28/6/1975.

O comprimento dos animais varia de $24-27 \mathrm{~mm}$ e o diâmetro na região media do corpo de $0,56-0,64 \mathrm{~mm}$. Pigmento falta. O número de segmentos varia de $100-123$. O prostômio (Fig. 11 - 12) é largo $€$ arredondado; penetra dorsalmente até a metade do primeiro segmento, do qual se separa por um suico, lembrando o do tipo epilobo. Os sulcos intersegmentares são bem demarcados apenas na região preclitelar. A partir do segmento II ocorrem 4 pares de cerdas por segmento, que se dispõem em séries longitudinais regulares. $\mathrm{Na}$ região entre os segmentos $\mathrm{XXX}-\mathrm{XL}$ a relação entre as cerdas em dois exemplares é $a a: a b: b c: c d: d d=4,18: 1,00: 6,90: 1,09:$ $5,27=4,38: 1,00: 7,42: 1,04: 5,52$. As cerdas são sigmóides, alongadas e com um pequeno nódulo submediano; ornamentação ausente (Fig. 13). O comprimento das cerdas, na região mediana do corpo, varia de $120-140$ $\mu \mathrm{m}$, em média $130 \mu \mathrm{m}$. As cerdas ventrais de XIII faltam. Em seu lugar, encontra-se, de cada lado, uma cerda penial de ponta simples, sem ornamentação. O clitelo é anelar nos segmentos $1 / 2 X I I-1 / 2 X V, X V(=3-3,5$ segmentos). O par de poros masculinos localiza-se no equador de XIII, em linha com as cerdas $b$ dos segmentos adjacentes e associado às cerdas peniais. O par de poros femininos aparece como uma fenda larga e transversal em 13/14, na linha e pouco ao lado da série de cerdas $b$ (Fig. 14). Um poro de espermateca impar e mediano dorsal abre-se em $8 / 9$; o poro pede ser simples ou rodeado por pequena papila.

Os septos 4/5 - 11/12, 12/13 são pouco mais espessos do que os demais e não se in- serem nos intersegmentos correspondentes mas, no meio ou pouco atrás nos segmentos imediatamente anteriores. Não foi possível estabelecer um limite preciso entre o esôfago e o intestino. Este começa a dilatar-se em IX, porém só atinge seu diâmetro normal posterior a partir de XV ou XVI. Moela, tiflosole e divertículos do tubo digestivo ausentes. Glândulas septais aparecem nos segmentos $V$ VIII, presas à face anterior dos septos $5 / 6$ - 8/9.

Do aparelho circulatório, ao lado dos vasos dorsal e ventral, bem nítidos em dissecação e cortes, foi-nos possível reconhecer 3 pares de alças largas e moniliformes, lembrando corações laterais nos segmentos IX-XI. Vaso subneural ausente. Um par de testículos situase em X, cuja cavidade contém espermatozóides em diferenciação. Um par de vesículas seminais pode ou não aparecer em XI. Os canais deferentes não são visíveis em dissecação mas puderam ser seguidos em cortes seriados. Cada canal deferente corre sobre a parede do corpo em XI e XII, na linha das cerdas ventrais. Após perfurar o septo $12 / 13$, o canal deferente (Fig. 15, CD) eleva-se lateralmente para abrir-se no sexto ental do átrio. Os canais deferentes são bastante delgados e aparentemente intracelulares; seu diâmetro externo varia de $6-7 \mu \mathrm{m}$. Cada átrio aparece como um tubo longo, relativamente largo e enovelado, especialmente nos seus $3 / 4$ entais (AT), que são envolvidos por uma camada delgada $\mathrm{e}$ irregular de células glandulares, que provavelmente correspondem a uma próstata difusa. $\mathrm{O}$ átrio abre-se no fundo de uma curta invaginação da superfície, com fraco revestimento cuticular externo e delgada capa muscular interna (pseudopenis ?). Na porçăo mais superficial desta invaginação e, por vezes, imediatamente anterior a ela, abre-se o folículo da cerda penial (CP). Um parátrio (PA) tubular, longo e pouco dobrado acompanha o quarto ectal do átrio e termina junto à sua porção mediana em fundo cego. Na porção mais ectal, o revestimento superficial do átrio e do parátrio funde-se, porém os lumens permanecem independentes até abrirem-se, lado a lado, no fundo da invaginação superficial. Em alguns animais, o átrio e o parátrio restringem-se ao segmento XIII, em outros penetram, em parte, na região anterior do ovisaço em XIV. Nos cortes seriados corados pelo método de Mallory 
(Pantin, 1964: 41) é possível reconhecer 4 regiões sucessivas no átrio. A porção mais ental e delgada termina em fundo cego. Seu comprimento equivale a $1 / 6$ do comprimento total do átrio. $\mathrm{O}$ diâmetro médio é de $17 \mu \mathrm{m}$ e a parede é formada por células cônicas, sem inclusões granulares no plasma (Fig. 16). No lúmen, como no dos canais deferentes, encontram-se espermatozóides. A transição entre esta região e a seguinte é brusca peıa composição celular da parede, mas não pelo diâmetro que aumenta gradativamente. A segunda região é a mais enovelada e de cor branca leitosa em dissecação. Seu comprimento equivale a cerca de $2 / 4$ do comprimento do átrio e o diâmetro médio externo é de $37 \mu \mathrm{m}$. A parede é formada por células altas, com o plasma totalmente preenchido por grânulos grossos que se coram em vermelho vivo. Por fora há uma camada conjuntivo-muscular como nas demais regiões do átrio. As células da "próstata" desta região apresentam-se ricas em grânulos semelhantes (Fig. 17). A região seguinte é pouco dobrada, podendo penetrar no ovisaco. O diâmetro médio e a forma das células de revestimento é semeihante ao da região precediente. Difere pelos grânulos plasmáticos que, embora corados de vermelho, são muito finos; o mesmo tipo de grânulos aparece nas células da "próstata" (Fig. 18). Em direção ectal, os grânulos que eram numerosos, tornam-se esparsos e começam a surgir grânulos grossos corados de azul. Na região mais ectal a organização é semelhante, porém a bainha conjuntivo-muscular é mais espessa e os grânulos plasmáticos, grossos e compactamente distribuídos, coramse de azul (Fig. 19). Nesta região, falta a camada glandular externa.

O diâmetro médio do parátrio é de $27 \mu \mathrm{m}$. A parede é formada por um epitélio cúbico, onde se encontram grânulos finos, mais ou menos esparsos e corados em vermelho. Externamente, só se reconhece uma fina capa conjuntiva e o epitélio pavimentoso do celoma (Fig. 20) . Na extremidade ectal, o átrio e o parátrio têm um revestimento conjuntivo e muscular comum. O lúmen de ambos os dutos é formado por células cúbicas, sem inclusões diferenciadas. Nos 4 exemplares estudados em cortes, a relação entre o diâmetro ex- terno na região média do átrio e o do corpo em micra varia de $30: 435 \mu \mathrm{m}$ a $45: 462,5 \mu \mathrm{m}$, o que equivale a 0,068 e 0,097 respectivamente.

Um par de ovários prende-se à face posterior do septo 12/13. Cada ovário (Fig. 15, O) faz uma alça do lado interno da genitália masculina e penetra no ovisaco (OV), percorren-do-o longitudinalmente. De ponto em ponto, ao longo dos ovários, encontram-se ovos com maior ou menor quantidade de vitelo. Os ovos maiores encontram-se no interior dos ovisacos, que podem atingir até o segmento XVII. A espermateca única situa-se dorsalmente em IX. Seu duto é largo e de parede grossa, formada por células cilindricas envolvidas por espessa capa de musculatura circular. O comprimento do duto equivale a metade do diâmetro da ampola, que tem parede fina e forma arredondada ou ligeiramente ovóide (Fig. 21). No interior da ampola, encontram-se espermatozóides envolvidos por uma massa amorfa que se cora de azul pelo método de Mallory.

\section{CONSIDERAÇõES}

Não temos dúvidas quanto a identidade de nossos animais com Brinkhurstia americanus conhecida da Argentina, Arroyo Pastora e sumariamente estudada por Brinkhurst (1964: 533) e Jamieson (1968: 80) dada a pobreza do material.

Nossas observações da parte terminal do aparelho masculino divergem muito das de Jamieson (l.c.). Em nosso material, o canal deferente, muito delgado, abre-se no sexto ental do átrio e não ao lado deste na invaginação superficial ou pseudopenis (= câmara ectal de Jamieson). Provaveimente, este autor não pode seguir o canal deferente desde o funil masculino. Assim, o que ele designou e figurou como largo canal deferente em XIII corresponde ao parátrio de nosso material, que verificamos terminar em fundo cego. Dentro das Aliuroididae, a abertura do canal deferente no átrio é típica de Alluroides Beddard, 1894. Contudo, mantivemos o nome genérico Brinkhurstia porque em nenhuma espécie de Alluroides é conhecido um parátrio. 


\section{GLOSSOSCOLECIDAE}

Atatina gatesi, sp. n. (Fig. 22)

\section{MATERIAI}

Brasil, Amazonas : Estrada Manaus-Itacoatiara, Km 38 , no solo periodicamente inundado da margem de um igarapé, 1 exemplar clitelado (INPAZ-71), L. Antony \& G. Righi col. 25/6/1975.

O comprimento do animal é de $26 \mathrm{~mm}$, porém falta a região posterior. O diâmetro preclitelar é de $0,88 \mathrm{~mm}$, no clitelo $0,97 \mathrm{~mm}$, na região mediana $0,70 \mathrm{~mm}$ e na posterior $0,58 \mathrm{~mm}$. O número de segmentos é 108. O prostômio apresenta-se como um cilíndro curto, dilatado na extremidade livre e esta invaginado, juntamente com o primeiro segmento. O segmento II é percorrido por um par de sulcos longitudinais profundos, na linha dos nefridióporos. Os demais segmentos têm a superfície lisa. A cor geral do corpo é branca opaca e o clitelo branco leitoso. O clitelo ocupa os segmentos XIV-XXI $(=9)$; é intumescido dorsal e lateralmente e aberto ventralmente, porém sem limites definidos. Em $b c$ de XVIII-XX o clitelo apresenta-se pouco mais expandido lateralmente do que nos demais segmentos. Outras marcas pubertais acessórias faltam. As cerdas dispõem-se em 8 linhas longitudinais regulares a partir de III. São sigmóides e alongadas, com ligeiro espessamento submediano e terminam em ponta simples, sem ornamentação. $\mathrm{Na}$ região dos segmentos XXXII-XXXVI a relação entre as cerdas é $a a: a b: b c: c d: d d=2,90: 1,00:$ $4,63: 1,00: 13,36$.

Os septos $9 / 10$ e $10 / 11$ são pouco mais espessos do que os demais que são frágeis. Os $6 / 7-10 / 11$ têm a forma de cones interpenetrados dado o grande desenvolvimento da porção anterior do trato digestivo. Os demais septos são transversais. A massa faríngea segue-se um volumoso papo, que se abre em uma moela musculosa e cônica em VI mas, corresponde externamente aos segmentos IX * $X$. O esôfago posterior é moniliforme, mais dilatado em X-XIV. Sua parede é espessa e de cor branca leitosa em XI-XVI; a mucosa eleva-se em dobras verticais em XI-XIV, cons- tituindo as glândulas calcíferas. O intestino inicia-se em XVII e em XVIII já atinge o diâmetro do intestino. Um tiflosole lateral esquerdo é reconhecivel em XXI-XXIX como uma pequena dobra longitudinal de cor branca leitosa e mais alta em XXI - XXIII, onde atinge $1 / 3$ da altura do tiflosole dorsal.

Quatro pares de corações intestinais encontram-se em X-XIII e 3 pares de corações laterais em VII-IX. Em cada segmento, há um par de holonefrídios. Os nefrídios de VI e anteriores enovelam-se dos lados do esôfago anterior. Os nefridióporos são nítidos a partir de $6 / 7$, em série com as cerdas laterais. Um par de sacos testiculares situa-se ventralmente ao esôfago em XI. Um par de vesículas seminais em forrna de fita, fouco mais espessa em XII e XIII, segue uma trajetória sinuosa até o segmento XXI. Um par de ovários laminares e do funis ovulares situa-se em XIII. Um par de espermatecas pequenas localiza-se em $X$. Em cada espermateca (Fig. 22) o duto é espesso e pouco mais curto do que a ampola que é ovóide. Os poros das espermatecas, irreconhecíveis externamente, situam-se em 10/11, na linha dos nefridióporos.

\section{CONSIDERAÇÕES}

Do gênero Atatina Righi, 1971a, conhece-se apenas a espécie tipo, A. puba Righi, 1971, descrita do Pará, Belém. As duas espécies podem ser separadas pelos seguintes caracteres: A. gatesi - clitelo de XIV-XXII (A. puba - de XIV - XXIII); poros das espermatecas em 10/11 (em 9/10); glândulas calcíferas năo pedunculadas em XI-XIV (em IX-XIII) .

O nome da nova espécie foi dado em homenagem ao ilustre oligoquetólogo Prof. Dr. G. E. Gates.

Amazo Righi et al., 1976

$\mathrm{Na}$ descrição original de Amazo nia e diagnose do então novo gênero Amazo, indicamos a presença de glândulas calciferas apenas como dilatações do esôfago com estrutura trabecular nos segmentos XV - XVI.

Reexaminando o material típico de $A$. nia para comparações, encontramos 3 pares de glândulas calcíferas extramurais nos segmen- 
tos VII - IX, que passaram despercebidas no estudo anterior. Estas glândulas são pequenas, digitiformes e abrem-se de cada lado da linha média ventral do esôfago. Elevam-se até à região média lateral do esôfago, onde terminam em fundo cego. Sua parede é ricamente vascularizada e internamente forma pequenas trabéculas irregulares e descontínuas (Fig. 23).

Assim, a diagnose de Amazo deve ser acrescida da presença de 3 pares de glândulas calcíferas do tipo trabecular em VII - IX. Este carácter aproxima-se do gênero Diachaeta Benham, 1887, do qual se separa pela posição das espermatecas, que são pretesticulares em Diachaeta e postesticulares em Amazo.

\section{Amazo atroaris, sp. $\mathrm{n}$.} (Fig. 24-26)

\section{MATERLAL}

Brasil, Amazonas : Estrada Manaus-Itacoatiara, $\mathrm{Km}$ 26 (Reserva Ducke), margem do Igarapé do Barro Branco, próximo a um chiqueiro, 1 exemplar clitelado (INPAZ-70), L. Antony \& G. Righi col. 23/6/1975.

O comprimento do animal é de $33 \mathrm{~mm}$ e o diâmetro na região mediana do corpo 1,1 $\mathrm{mm}$. Pigmento ausente. O número de segmentos é 105. O prostômio longo e tentaculiforme está invaginado em uma bainha que se prende dorsalmente na parede de IV. O clitelo ocupa os segmentos XIV $-\mathrm{XX}(=7)$; é anular em XVII - XX e aberto ventralmente, porém sem limites definidos, em XIV - XVI. Dois pares de papilas volumosas salientam-se na metade posterior de XV e XVI. As papilas de cada lado unem-se entre si por um sulco longitudinal irregularmente ondulado (Fig. 24). A face ventral de XV e XVI, entre as papilas, é algo deprimida. Dois pares de poros de espermatecas situam-se em $13 / 14$ e $14 / 15$, pouco laterais à linha de cerdas $b$. Um par de reentrâncias de cor branca brilhante encontram-se em série com as papilas em 17/18.

As cerdas dispõem-se em 8 séries longitudinais regulares a partir do segmento III. As cerdas são sigmóides, alongadas, com um nódulo subesférico no início do terço distal. A extremidade apical é bicuspidada, sendo o cúspide proximal consideravelmente maior (Fig. 25) . Ornamentação ausente. Em 10 medidas, o comprimento das cerdas da região mediana do corpo variou de $135-155 \mu \mathrm{m}$, em média $147 \mu \mathrm{m}$. A relação entre as cerdas na região mediana do corpo (segmentos XXXIII XXXVI) é $a a: a b: b c: c d: d d=5,14: 1,00$ : $6,78: 1,00: 14,71$ e na regiăo posterior (segmentos XCIX - CIII) é $a a: a b: b c: c d: d d=$ $2,84: 1,00: 3,27: 1,00: 9,00$.

Os septos $6 / 7$ - 8/9 são cônicos e pouco transversais. Uma moela cônica, com a extremidade afilada posterior, situa-se em VI. O esôfago posterior é moniliforme. Três pares de glândulas calcíferas pequenas, piriformes e de estrutura trabecular situam-se ventralmente ao esôfago em VII - IX. Em XV e 1/2 XVI o esôfago forma duas pequenas expansões laterais de cor branca leitosa e estruturadas por numerosas trabéculas verticais, constituindo glândulas calciferas intramurais. O intestino inicia-se em XVIII e em XXII atinge o diâmetro normal posterior. Cecos intestinais ausentes. O tiflosole apresenta-se como uma lâmina dorsal, baixa e ondulada a partir de XViil. Quatro pares de corações intestinais situam-se em X - XIII e três pares de corações laterais em VII - IX. Em cada segmento, há um par de holonefrídios que se abre na região anterior dos segmentos, em série com as cerdas c. De cada lado do esôfago, em XV e XVI, encontram-se numerosos tufos glandulares associados às papilas e sulcos da superfície.

Um par de testículos e de funis seminais encontram-se livres na cavidade do segmento $\mathrm{XI}$, que está repleta de espermatozóides. Um par de vesículas seminais lobuladas recobre o esôfago em XII. O par de canais deferentes pouco ondulados pôde ser seguido sobre a parede ventral do corpo até o terço inicial de $\mathrm{XV}$, onde penetra na musculatura parietai. Um par de ovários laminares prende-se à face ventral e posterior do septo $12 / 13$. Dois pares de espermatecas, aproximadamente do mesmo tamanho, situam-se em XIII e XIV. Em cada espermateca (Fig. 26) a ampola é arredondada e bem separada do duto, cujo comprimento equivale ao diâmetro da ampola. 

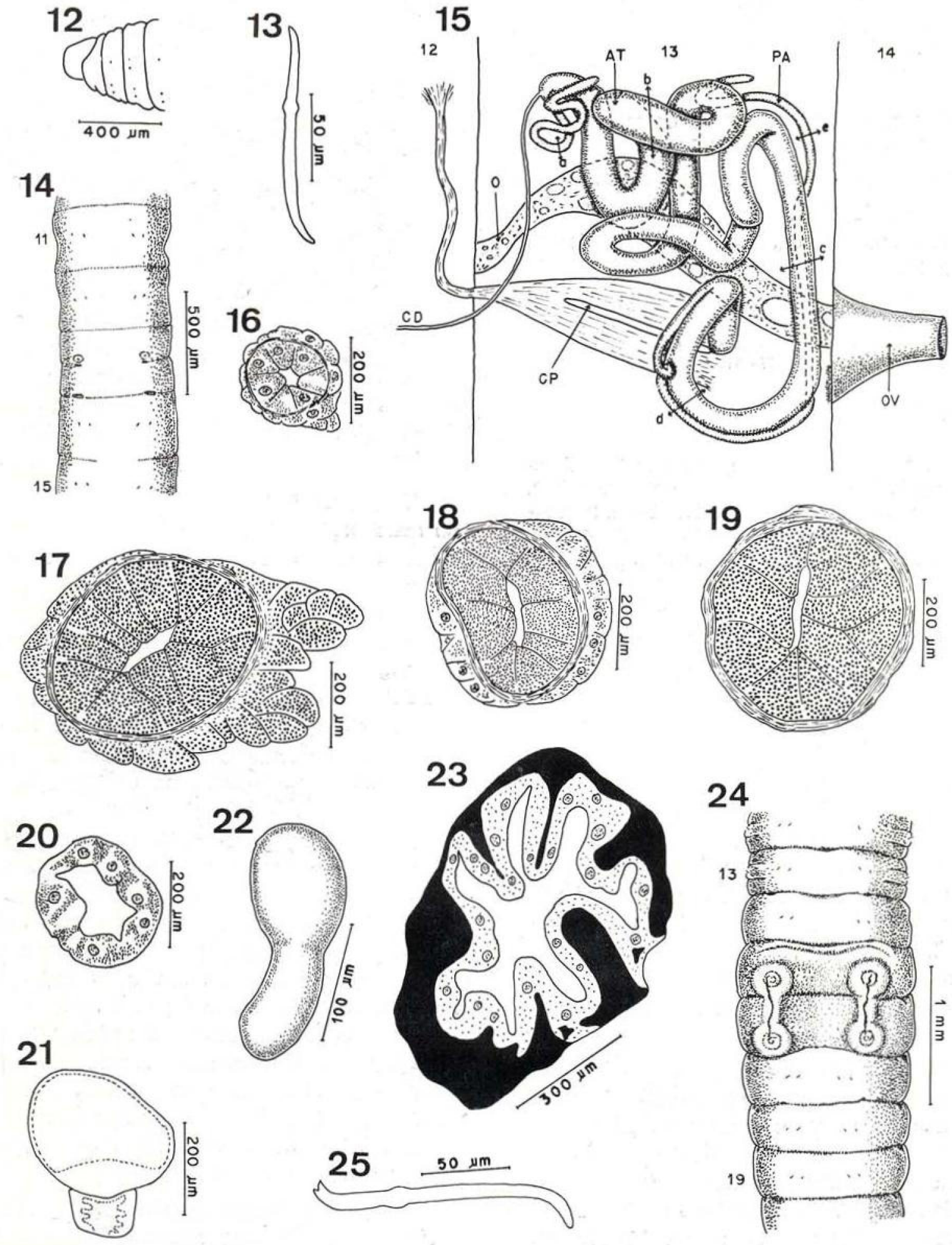

ESTAMPA II - Brinkhurstia americanus (Brinkhurst, 1964) : 12 - extremidade anterior em vista lateral; 13 - cerda da regiãomediana do corpo; 14 - face ventral dos segmentos XI-XV; 15 - parte do aparelho reprodutor no segmento XIII; $16-$ corte transversa| da porçăo ental do átrio segundo Fig. 15, a; 17 - idem da porção mediana do átrio segundo Fig. 15, b; 18 - idem da porção média-ectal do átrio segundo Sig. 15, c; 19 — idem da porção ectal do átrio segundo Sig. 15, d; 20 - idem da porção mediana do parátrio segundo Sig. 15, e; 21 - espermateca. Atatina gatesi, sp. n.: 22 - espermateca de IX. Amazonia Righi et al., 1977: 23 - corte transversal da glấndula calcífera de VIII. Amazo atroaris, sp. n.: 24 - face ventral dos segmentos XIII-XIX; 25 - cerda ventral mediana. ( $A T=$ átrio; $\quad C D=$ canal deferente; $O=$ ovário; $O V=$ ovisaco; $a \cdot e=$ planos dos cortes das Figs. 16-20.) 
CONSIDERAÇÕES

Amazo atroaris distingue-se da outra única espécie do gênero, A. nia Righi et allis, 1976 pelas marcas pubertais e forma das cerdas.

O nome da nova espécie deriva de um grupo indígena da região de onde provieram os animais.

\section{Amazo xecatu, sp. $\mathrm{n}$.} (Fig. 27-31)

\section{MATERIAL}

Brasil, Amazonas : Sucunduri (próximo à confluência da estrada Transamazônica com o rio Sucunduri), em troncos podres no igarapé da Caixa d'Água, 3 exemplares clitelados e 1 maduro aclitelado (INPAZ-85), L. Antony, E. Rufino e G. Righi col. 26/6/1975.

Os 3 exemplares clitelados serão referidos abaixo por A, B e C. O comprimento, diâmetro na região mediana do corpo e número de segmentos são em $A=17 \times 0,72 \mathrm{~mm}, 83$ segmentos; $\mathrm{em} B=47 \times 1,26 \mathrm{~mm}, 100$ segmentos (faltam alguns posteriores); C está cortado na região mediana do coipo. O exemplar aclitelado mede $55 \mathrm{~mm}$ de comprimento por 1,02 $\mathrm{mm}$ de diâmetro e tem 116 segmentos. Em todos os exemplares, os segmentos têm a superfície lisa, exceto o primeiro que é totalmente percorrido por numerosos e delgados sulcos longitudinais. O prostômio é tentaculiforme e está parcialmente invaginado em uma bainha que se prende dorsalmente na altura do intersegmento $4 / 5$. Pigmento ausente.

O clitelo situa-se nos segmentos XIV - XX $(=7)$; é aberto ventralmente em XIV - XVI e anelar nos demais segmentos. Um par de traves pubertais, percorridas medianamente por um sulco longitudinal, estende-se do terço posterior de XV a 16/17, na metade ventral de $b c$. As traves, em B e no exemplar aclitelado, são retas, delgadas e pouco salientes (Fig. 27); em $A$ e $C$ são muito volumosas e com sulcos transversais irregulares (Fig. 28). Associadas às traves pubertais encontram-se células glandulares longas e piriformes, que se salientam na cavidade do corpo como duas massas longitudinais, laterais ao esôfago, na região posterior do segmento $X V$ e no $X V I$. Dois pares de poros de espermatecas situam-se na região posterior de XIII e XIV, em linha com a metade dorsal de $b c$. Os poros são pouco evidentes em B (Fig. 27) e situam-se em pequenas papilas em A e C (Fig. 28). Nefridióporos são reconheciveis a partir de $5 / 6$, em série com $c d$. As cerdas dispõem-se em 4 pares de séries longitudinais regulares a partir de II. Entre os segmentos XXII - XXX, a relação entre as cerdas é $a a: a b: b c: c d: d d=4,66: 1,00$ : $7,50: 1,00: 21,16$. As cerdas são sigmóides, com um nódulo submediano e a extremidade apical lisa e bicuspidada. O cúspide proximal é cerca de 2 vezes mais volumoso do que o distal (Fig. 29). O comprimento médio das cerdas da região mediana do corpo é $195 \mu \mathrm{m}$.

Os septos $6 / 7-9 / 10$ são cônicos e pouco mais espessos do que os demais que são transversais. Uma moela volumosa, fortemente muscular e ovóide situa-se em VI, porém devido ao seu tamanho distende os septos posteriores, ocupando o espaço correspondente aos segmentos VI - IX externos. Três pares de glândulas calciferas de estrutura trabecular abrem-se ventralmente no esôfago em VII - IX. As glândulas são piriformes, finas e longas, estendendo-se dós lados do esôfago até sua face dorsal. O esôfago apresenta-se pouco mais volumoso em XV e XVI, onde as paredes laterais elevam-se em numerosas lamelas dorso-ventrais, constituindo glândulas calcíferas intramurais. O intestino inicia-se em XVIII, já com o tiflosole. Este apresenta-se como uma lâmina espessa, perpendicular e de posição média dorsal; sua altura é pouco maior do que $2 / 3$ do diâmetro intestinal. Em cada segmento há um par de holonefrídios dotados de bexiga volumosa, que se abre na superfície por pequeno esfincter. Corações situam-se nos segmentos VII - XIII. O vaso dorsal é simples e retilíneo; vaso subneural falta.

Um par de testículos (Fig. 30, T) e de funis seminais (FS) encontram-se livres no segmento XI, cuja cavidade está cheia de espermatozóides. Um par de vesículas seminais (VS) profundamente lobuladas situa-se em XII. O par de canais deferentes (CD) é retilíneo sobre a parede ventral do corpo até o segmento XIV. Nesta região seu diâmetro externo é de $22 \mu \mathrm{m}$ e o epitélio de revestimento é cúbico, medindo $6 \mu \mathrm{m}$ de altura. Em 15/16 há uma transição brusca nos canais deferentes; o diâ- 
metro externo aumenta para $34 \mu \mathrm{m}$ e o epitélio tem $12 \mu \mathrm{m}$ de altura, sendo constituído por células nitidamente glandulares. Em XV, cada canal eleva-se paulatinamente junto da face medial da massa glandular (MG) das traves pubertais, até alcançar seu bordo superior em $X V I$. Concomitantemente seu calibre aumenta, até o máximo em XIV, onde o diâmetro externo é de $78 \mu \mathrm{m}$ e o epitélio cilíndrico glandular mede $21 \mu \mathrm{m}$ de altura. A seguir o canal deferente atravessa mais ou menos perpendicularmente a massa glandular das traves pubertais e seu diâmetro diminui sucessivamente até o poro masculino, no interior das traves pubertais em 1/2 XVI. Em XIII há um par de ovários flabelares $(\mathrm{O})$, com numerosas faixas regulares de ovos em diferenciação na porção mediana e que perdem a regularidade na margem. Dois pares de espermatecas (E) volumosas situam-se em XIII e XIV. Em cada espermateca (Fig. 31) a ampola é arredondada e seu diâmetro equivale ao comprimento do duto.

\section{CONSIDERAÇÕES}

Amazo xecatu distingue-se da espécie simpátrica, A. nia Righi et al., 1976 principalmente pela forma das traves pubertais e das cerdas. De A. atroaris Righi et al. distingue-se pela organização do campo genital masculino.

O nome da nova espécie deriva da lingua tupi, onde "xecatu" = reto, devido à forma das traves pubertais.

\section{Meroscolex eudoxiae, sp. $n$.}

(Fig. 32-38)

\section{MATERIAL}

Brasil, Amazonas : Estrada Manaus Itacoatiara, $\mathrm{Km}$ 26 (Reserva Ducke), em tronco pobre, 1 exemplar clitelado sem a extremidade posterior (INPAZ-82), E. M. Froehlich \& L. Antony col. 23/6/1975.

$\mathrm{O}$ animal fragmentado contém 181 segmentos. Seu comprimento é de $68 \mathrm{~mm}$ e o diâmetro posclitelar de $2,5 \mathrm{~mm}$. O primeiro segmento é rudimentar e esta invaginado, juntamente com_o prostômio. Pigmento falta. O clitelo ocupa os segmentos $1 / 2$ XIII - XXIV $(=11,5)$; é anelar em $1 / 2$ XIII - XIX e aberto ventralmente para trás. A face ventral de
XX - XXIII modifica-se como uma área genital masculina, de aspecto grosseiramente quadrangular, limitada lateralmente pela margem espessada do clitelo (Fig. 32). Papilas arredondadas envolvem as cerdas a e $b$, deixando um pequeno aprofundamento anterior, em cada um desses segmentos. Um par de traves pubertais estende-se de $1 / 2 X X-1 / 2 X X I I I$; as traves são sinuosas, interrompidas nos intersegmentos e englobam parcialmente as papilas das cerdas $b$. Três pares de papilas arredondadas e volumosas encontram-se na metade posterior dos segmentos XX - XXII, entre a margem do clitelo e as traves pubertais. A estas estruturas pubertais de cada lado correspondem, internamente, dois volumosos agrupamentos de células glandulares dispostos látero-ventralmente ao intestino de $1 / 2 \mathrm{XVIII}-$ $1 / 2$ XXIII. Em cada segmento de XIX - XXII, os agrupamentos glandulares estão subdivididos por fortes faixas musculares, que se prendem lateral e ventralmente na parede do corpo. Outras estruturas sexuais secundárias são os espessamentos da face ventral dos segmentos $\mathrm{XI}$ e XIX. Uma área circular e de aspecto glandular diferencia-se ao redor das cerdas ventrais de $\mathrm{XI}$.

As cerdas dispõem-se em 4 séries longitudinais regulares a partir do segmento III. Nos segmentos $X X X V$ - XLV a relação entre as cerdas é $a a: a b: b c: c d: d d=6,25: 1,00: 7,25:$ $0,83: 7,91$. As cerdas normais têm a forma de um $\mathrm{S}$ alongado, com pequeno espessamento submediano e superfície lisa. O comprimento das cerdas ventrais varia de $150-250 \mu \mathrm{m}$, em média $191 \mu \mathrm{m}$. As cerdas ventrais de XI e de XVIII - XXIV transformam-se em genitais. As de XVIII - XXIV (Fig. 33) são ligeiramente curvas na porção ental, com pequeno espessamento submediano e o terço apical ornamentado. A ornamentação (Fig. 34) consiste de 4 séries de escavações semilunares abertas para o ápice e dispostas 2 a 2 em alturas sucessivas e opostas. O número de cicatrizes por série varia de $5-7$, em geral 7 . O comprimento destas cerdas varia de 625 $700 \mu \mathrm{m}$, em média $659 \mu \mathrm{m}$ e o diâmetro basal de $25-30 \mu \mathrm{m}$, em média $27 \mu \mathrm{m}$. As cerdas de XI são quase retas (Fig. 35), sem espessamento diferenciado e os $3 / 5$ apicais ornamentados como as cerdas do clitelo. O compri- 
mento médio destas cerdas é de $825 \mu \mathrm{m}$ e o diâmetro basal $25 \mu \mathrm{m}$.

Os septos $6 / 7-12 / 13$ têm a forma de cones interpenetrados. Os $6 / 7-9 / 10$ são espessos e musculosos, os demais são frágeis. Uma moela fortemente muscular e subesférica situa-se em VI. Três pares de glândulas calcíferas prendem-se às paredes laterais do esôfago em VII - IX e dirigem-se para a frente e para cima. As glândulas são piriformes, sem apêndice terminal e de estrutura tubular composta. A transição esôfago - intestino situase em $14 / 15$. Até o segmento XXIII o intestino é pouco mais dilatado do que o esôfago. Em XXIV dilata-se bruscamente, continuando mais ou menos uniforme para trás. Um tiflosole com a forma de uma lâmina dorsal larga inicia-se em XXV. Dois pares de volumosos corações látero-intestinais encontram-se em X e XI e três pares de delgados corações laterais em VII - IX. Em cada segmento há um par de holonefrídios abrindo-se através de esfincter musculoso em série com as cerdas laterais.

Um par de sacos testiculares volumosos runde-se dorsalmente em XI, recobrindo o esôfago e o par de corações. Ventralmente os sacos estendem-se como lâminas para diante, acompanhando a forma dos septos. Os dois canais deferentes são retilíneos e puderam ser seguidos até o segmento XVIII, perdendo-se para trás no interior dos agrupamentos glandulares acima mencionados. Um par de vesículas seminais atinge o segmento XXXI. As vesículas são finas e lobuladas dos lados do intestino até o segmento XXIII; de XXIV para trás são largas, dorsais e sem lóbulos. Ovários e funis femininos não foram reconhecidos. Três pares de espermatecas situam-se nos segmentos VI - VIII, abrindo-se em 6/7 - 8/9, em série com os nefridióporos. As espermatecas são saculiformes (Figs. 36 - 38) e sem distinção nítida entre duto e ampola. As do primejro par são consideravelmente menores.

\section{CONSIDERAÇÕES}

Do gênero Meroscolex Cernosvitov, 1934 são conhecidas 4 espécies, todas da região amazônica (Righi \& Ayres, 1976: 262). M. eudoxiae, sp. n., próxima de $M$. marcusi Righi \& Ayres, 1976, distingue-se pela disposição dos caracteres sexuais secundários, bem como pela forma das cerdas normais e das glândulas calcíferas.

O nome da nova espécie foi dado em homenagem à Dra. Eudóxia Maria Froehlich, que coletou o material.

Diachaeta juli, sp n.

(Fig. 39-41)

\section{MATERIAL}

Brasil, Amazonas : Estrada Manaus-Rlo Branco, $\mathrm{Km}$ 45 (Reserva Biológica da Campina), em tronco podre junto ₹. um igarapé, 1 exemplar clitelado (INPAZ-81), L. Antony \& G. Righi col. 25/6/1975.

O comprimento do animal é de $25 \mathrm{~mm}$ e o diâmetro na região mediana do corpo $1,0 \mathrm{~mm}$ e no clitelo $1,4 \mathrm{~mm}$. O número de segmentos é 88. O prostômio tentaculiforme esta invaginado. Pigmento falta. As cerdas dispõem-se em 4 pares de séries longitudinais regulares ao longo de todo o corpo, a partir do segmento II. Na região mediana do corpo as cerdas têm a forma de um $\mathrm{S}$ alongado, com pequeno nódulo submediano e a extremidade distal lisa e bicuspidada (Fig. 39). O cúspide proximal é volumoso e cerca de 2 vezes mais longo do que o distal. O comprimento médio destas cerdas varia de $115-130 \mu \mathrm{m}$, em média 120 $\mu \mathrm{m}$. Nos segmentos $X X X V-X L$, a relação entre as cerdas é $a a: a b: b c: c d: d d=4,0: 1,0:$ $6,7: 1,0: 16,0$.

O clitelo é anelar nos segmentos $1 / 2$ XIII $X X(=7,5)$. Na metade posterior de XVI, em linha com $1 / 2 b c$, há um par de papilas pubertais circulares, com o bordo recortado. Da região central de cada papila salienta-se para a frente uma pequena projeção mamilar. Um par de pequenos sulcos longitudinais situa-se em linha com as papilas pubertais na metade an. terior de XVI e no terço anterior de XVII (Fig. $40)$. Os poros genitais são visíveis apenas em cortes.

Os septos $6 / 7-9 / 10$ têm a forma de cones interpenetrados. Os $7 / 8-9 / 10$ são pouco mais espessos do que os demais. Uma moela cônica, volumosa e fortemente muscular situase em Vl. Três pares de glândulas calcíferas pequenas, digitiformes e de estrutura trabecular (Fig. 41) abrem-se no esôfago, próximo 

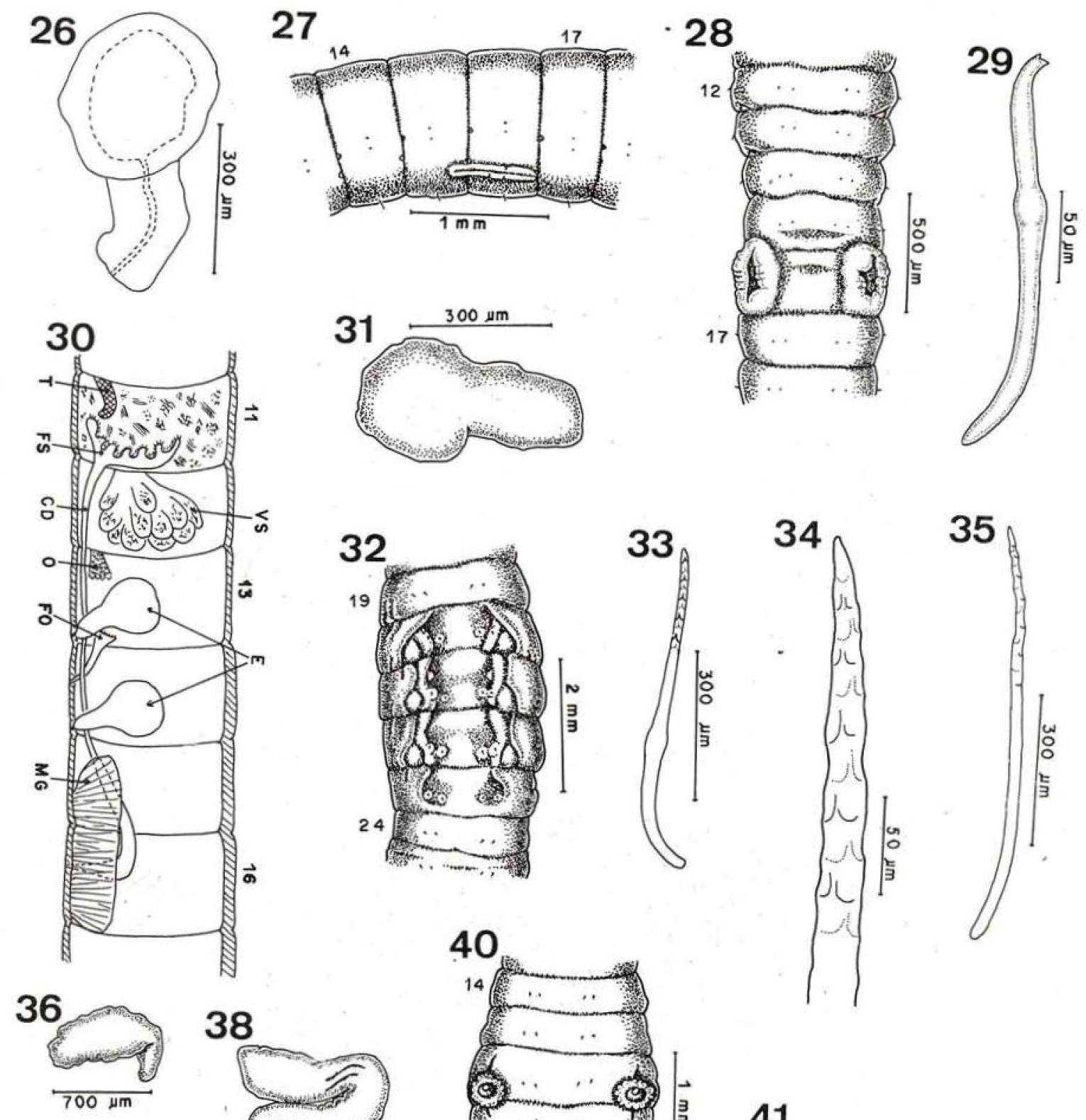

38
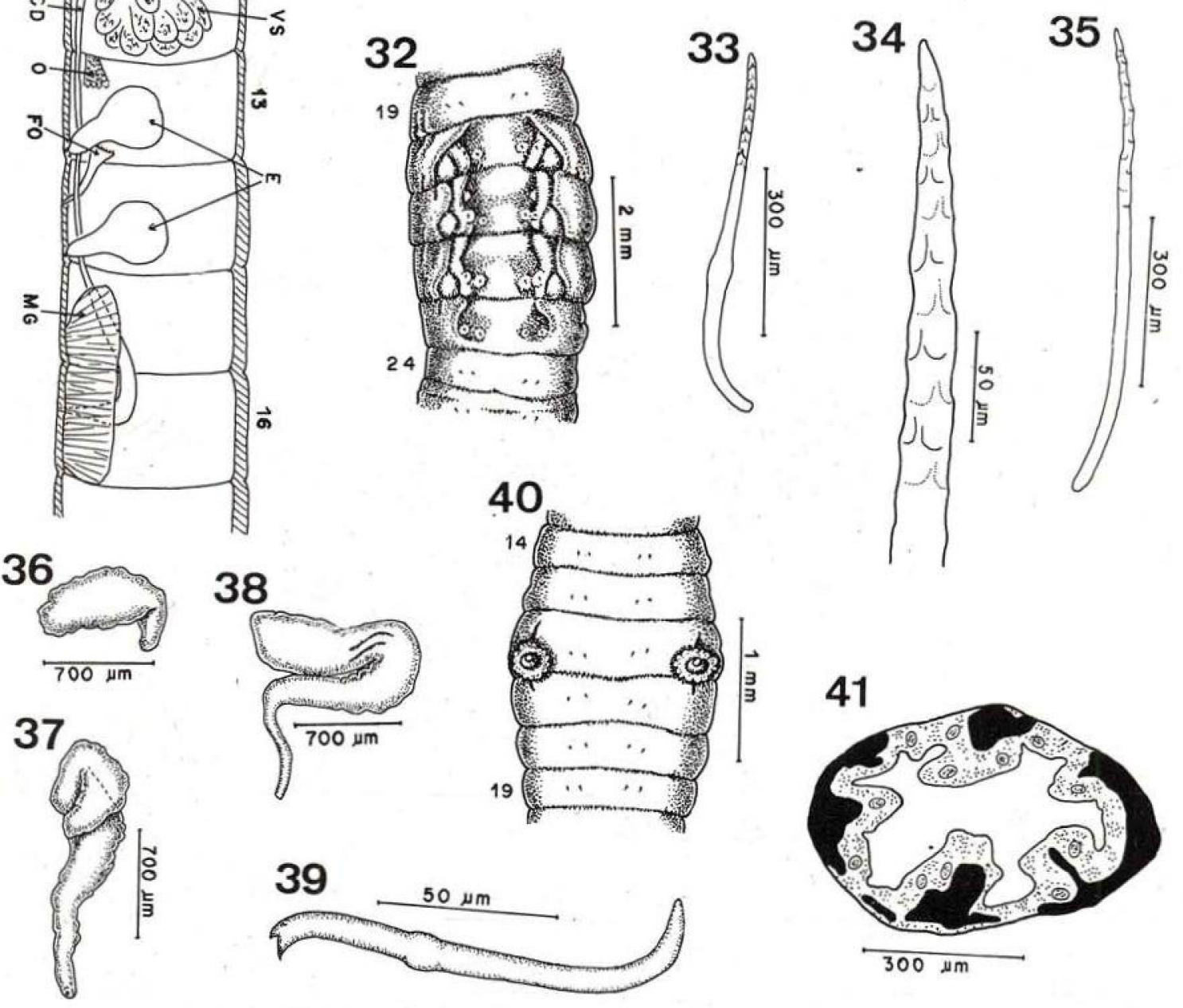

ESTAMPA III - Amazo atroaris, sp. n.: 26 - espermateca de XIII. Amazo xecatu, sp. n.: 27 - vista lateral dos segmentos XIV-XVII; 28 - face ventral dos segmentos XII-XVII; 29 - cerda ventral do segmento XXV; 30 - esquema da disposiçăo do aparelho reprodutor; 31 - espermateca de XIV. Meroscolex eudoxiae, sp. $\mathrm{n} .:$ 32 - face ventral dos segmentos XIX-XXIV; 33 - cerda genital de XX; 34 - ápice da cerda genital de XX; 35 - cerda de $\mathrm{XI} ; 36$ - espermateca de VI; 37 - espermateca de VII; 38 - espermateca de VIII. Diachaeta juli, sp. n.: 39 - cerda da regiăo mediana do corpo; 40 - face ventral dos segmentos XIV-XIX; 41 - corte transversal da glândula calcífera de $I X . \quad(C D=$ canal deferente; $F O=$ funil ovular; $F S=$ funil seminal; $M G$ = massa glandular; $\mathrm{O}=$ ovário; $\mathrm{T}=$ testículo.) 
à linha média ventral, em VII - IX. Numerosas lamelas altas, lembrando estruturas calcíferas, salientam-se na cavidade do esôfago, da porção posterior de XIII à anterior de XVI. O intestino inicia-se em XVIII e o tiflosole em XX, como uma larga lâmina dorsal. Três pares de corações laterais delgados encontram-se em VII - IX e 4 pares de volumosos corações látero-esofágicos em X - XIII. Vaso subneural falta. Em cada segmento há um par de holonefrídios, com os nefridióporos dispostos nos intersegmentos, em série com $c d$.

Um par de volumosos sacos testiculares desenvolvem-se dos lados do esôfago em XI. Duas vesículas seminais lobuladas restringemse à cavidade de XII. Um par de canais deferentes corre sobre a parede ventral do corpo até o segmento $\mathrm{XVI}$, onde abre diretamente na superfície, imediatamente na frente das papilas pubertais. O diâmetro interno dos canais é mais ou menos uniforme, ao redor de $13 \mu \mathrm{m}$. No segmento XVI, cada canal é revestido por espessa capa muscular e no lúmen abrem-se várias glândulas unicelulares. O diâmetro externo dos canais, neste segmento, é de $45 \mu \mathrm{m}$ e nos anteriores $21 \mu \mathrm{m}$. Um par de ovários prende-se ventro-lateralmente na face posterior de $12 / 13$. Os ovidutos curtos abrem- se em $1 / 2$ XIV, imediatamente na frente das cerdas $b$. Espermatecas faltam.

\section{CONSIDERAÇÕES}

Michaelsen (1918: 239) revendo o gênero Diachaeta Benham, 1887 reconheceu duas espécies, D. thomasi Benham, 1887 e D. barbadensis (Beddard, 1892). Posteriormente foram descrita $D$. exul Stephenson, 1931a e $D$. carsevenica Cernosvitov, 1934. Para a distribuição geográfica destas espécies veja-se Righi (1971a: 72) .

Pelas descriçōes de Cernosvitov (1934: 55; 1935: 26) D. carsevenica apresenta apenas dois pares de glândulas calcíferas localizadas nos segmentos VII e VIII. Isto afasta-a do gênero Diachaeta e justificaria sua separação em um novo gênero das Glossoscolecidae. Contudo, pela figura de Cernosvitov (1935, est. 5 , fig. 57), as glândulas situam-se em VIII e IX, o que motivaria sua transferência para o gênero Cirodrilus Righi, 1975. Ante isso, consideramos Diachaeta carsevenica como "species inquirenda".

As espécies reconhecidas de Diachaeta podem ser separadas pela Tabela 2 . O nome da nova espécie deriva da palavra latina "juliani".

TABELA 2 - Comparação entre as espécies de Diachaeta Benham, 1887

\begin{tabular}{|c|c|c|c|c|c|c|c|}
\hline Diachaeta & $\begin{array}{l}\text { Compri- } \\
\text { mento } \\
\text { em mm }\end{array}$ & $\begin{array}{l}\text { Número de } \\
\text { segmentos }\end{array}$ & $\begin{array}{l}\text { Disposição das } \\
\text { cerdas }\end{array}$ & Clitelo & $\begin{array}{c}\text { Marcas } \\
\text { pubertais }\end{array}$ & $\begin{array}{l}\text { Esperma- } \\
\text { matecas }\end{array}$ & $\begin{array}{l}\text { Poros } \\
\text { mascu- } \\
\text { linos }\end{array}$ \\
\hline thomasi & 76 & 335 & $\begin{array}{l}\text { b, c e d dispos- } \\
\text { postas em } \\
\text { quincunce }\end{array}$ & XX-XXXIII & $\begin{array}{l}\text { Traves pubertais } \\
\text { em XXV-XXXII }\end{array}$ & $6 / 7-8 / 9$ & XXII \\
\hline $\begin{array}{l}\text { barba- } \\
\text { densis }\end{array}$ & 24 & 84 & $\begin{array}{l}8 \text { séries regu- } \\
\text { lares }\end{array}$ & XIII-XXII & ? & $9 / 10-11 / 12$ & XVII? \\
\hline exul & $48-70$ & $151-154$ & idem & $X I V-X X$ & $\begin{array}{l}\text { Sulcos obliquos } \\
\text { de margem es- } \\
\text { pessa na metade } \\
\text { anterior de XVIII }\end{array}$ & faltam & XVIII \\
\hline juli & 25 & 88 & idem & $\begin{array}{l}1 / 2 \mathrm{XIII-} \\
\mathrm{xX}\end{array}$ & $\begin{array}{l}\text { Papilas volumo- } \\
\text { sas na metade } \\
\text { anterior de XVI }\end{array}$ & faltam & XVI \\
\hline
\end{tabular}


Holoscolex caramuru Righi, 1975

(Fig. 42-43)

Holoscolex caramuru Righi, 1975 : 83, fig. 9-11.

\section{MATERIAL}

Brasil, Amazonas: sob Hevea brasiliensis (seringueira) próximo ao lago Calado, 5 exemplares clitelados e 11 jovens (INPAZ-79), M. Knoflacher col. 1975.

Nossos exemplares diferem pouco do material típico, conhecido do Amapá (Righi, 1975; 83). As traves pubertais são mais espessas e percorridas medianamente por uma faixa longitudinal de cor branca leitosa. Em um exemplar estende-se de $1 / 2 \mathrm{XIX}-1 / 2 \mathrm{XXI}$. Nos outros 4 animais maduros as traves alongamse por 3 segmentos, de XIX - XXI. Papilas pubertais faltam em 2 animais. Nos outros 3 ocorrem pequenas papilas cônicas distribuídas diferencialmente como segue: Animal A: par de papilas em IX $b c$, papila impar esquerda em XIV $a b$ e impar direita em XVII $a b$. Animal B: pares de papilas em IX $b c$ e XVIII $b$. Animal C: par de papilas em XVIII b.

Os dois pares de espermatecas são salientes na cavidade dos segmentos VIII e IX e não mergulhadas na musculatura parietal como na forma típica. As espermatecas são saquiformes (Fig. 42 - 43), sem distinção entre duto e ampola e as do segundo par são as maiores.

\section{Holoscolex nemorosus tacoa, subsp. $n$.} (Fig. 44-45)

\section{MATERIAL}

Brasil, Amazonas: Estrada Manaus Itacoatiara, Km 10-15, 9 exemplares clitelados e 5 maduros aclitelados (INPAZ-66), E. F. Nascimento col. 4/1975.

O comprimento dos animais clitelados varia de $34,5-38,0 \mathrm{~mm}$. O diâmetro no segmento IX varia de $1,00-1,15 \mathrm{~mm}$, no clitelo de $1,17 \cdot 1,30 \mathrm{~mm}$ e nas regiões mediana e posterior do corpo de $0,88-1,00 \mathrm{~mm}$. O número de segmentos varia de $94-116$. O prostômio esta invaginado em todos os exemplares. Os animais são esbranquiçados, exceto o clitelo que é róseo pálido, semelhante ao $\mathrm{n}^{\circ}$ 20 de Séguy (1936), e uma faixa dorso-lateral em $1 / 2$ XXII - $1 / 2$ XXIII de cor castanha, como o n. ${ }^{\circ} 337$.
O clitelo é em forma de sela nos segmentos XVI - XXII $(=7)$. Um par de traves pubertais pouco salientes e de cor branca leitosa situa-se em série com as cerdas $b$ em $1 / 2$ $X I X-1 / 2 X X I$.. Os poros genitais foram reconhecidos apenas em cortes microscópicos. Os poros masculinos situam-se no segmento $X X$, no interior das traves pubertais. Dois pares de poros de espermatecas situam-se em $7 / 8 \mathrm{e}$ $8 / 9$, no terço ventral de $b c$. Os ovidutos não puderam ser seguidos nos cortes devido ao precário estado de conservaçăo dos animais. As cerdas dispõem-se em 4 pares de séries longitudinais regulares a partir do segmento II. São sigmóides e com ligeiro espessamento submediano. As relações entre as cerdas nas regiões mediana e posterior do corpo de 4 exemplares encontram-se na Tabela 3 .

Os septos $6 / 7 \cdot 9 / 10$ são espessos e musculosos, o $10 / 11$ pouco menos e os demais são frágeis. Os $6 / 7-12 / 13,13 / 14$ são cônicos e interpenetrados, os restantes são transversais. Uma moela mais ou menos globóide e musculosa situa-se em VI. Um par de glândulas calciferas volumosas, de posiçắo látero-dorsal ao esôfago, encontra-se em XI - XII, distendendo o septo 12/13 para trás. Cada glândula (Fig. 44) compõe-se de uma porção basal de estrutura tubular composta e de um reservatório membranoso dorsal, onde se encontram restos de calcário sob a forma de pó fino. A porção anterior do reservatório continua como curto duto que se abre, juntamente com o simétrico, na linha média dorsal do esôfago em XI. O intestino inicia-se em XV e o tiflosole aparece a partir de XVI, como uma lâmina dorsal, pequena e ondulada. O vaso dorsal faz uma alça dorsal entre as glândulas calcíferas, como em Holoscolex caramuru Righi $(1975$, fig. 11) e continua retilíneo sobre o esôfago até o segmento VII. Corações encontram-se em VII - XI. Os de VII - IX são do tipo de corações laterais; nos de $\mathrm{X}$ e XI não foi possivel estabelecer as conexões dorsais. Em cada segmento há um par de holonefrídios abrindo-se através de pequeno esfincter em série com as cerdas $b$.

Dois pares de testículos e de funis seminais encontram-se livres em $X$ e XI. Dois pares de vesículas seminais pequenas situamse em XI e XII. As do primeiro par apõem-se látero-dorsalmente ao esôfago como um cola- 
TABELA 3 - Holoscolex nemorosus tacoa, relaçöes entre as cerdas nas regiōes mediana e posterior do corpo de 4 animais

\begin{tabular}{|c|c|c|c|c|c|c|c|c|c|c|c|c|c|c|c|c|c|c|}
\hline \multirow[b]{2}{*}{ Exemplar } & \multicolumn{9}{|c|}{ Segmentos L-LV } & \multicolumn{9}{|c|}{ Segmentos C.CV } \\
\hline & aa & : & ab & : & bc & $:$ & cd & : & dd & aa & : & $a b$ & : & bc & : & cd & : & dd \\
\hline A & 2,13 & : & 1,00 & : & 1,21 & : & 0,86 & : & 1,47 & 1,51 & : & 1,00 & : & 1,07 & : & 0,90 & : & 0,81 \\
\hline B & 1,98 & : & 1,00 & : & 1,13 & $:$ & 0,84 & : & 1,35 & 1,60 & : & 1,00 & : & 0,96 & : & 0,85 & : & 0,96 \\
\hline C & 2,06 & : & 1,00 & $:$ & 1,10 & : & 0,89 & : & 1,10 & 1,65 & : & 1,00 & : & 1,03 & : & 0,86 & : & 0,93 \\
\hline D & 2,12 & : & 1,00 & : & 1,22 & : & 0,87 & : & 1,50 & 1,68 & : & 1,00 & : & 1,00 & : & 0,85 & : & 0,84 \\
\hline Média & 2,07 & : & 1,00 & : & 1,16 & : & 0,86 & : & 1,35 & 1,61 & : & 1,00 & : & 1,01 & : & 0,86 & : & 0,88 \\
\hline
\end{tabular}

rinho branco. As do segundo par apõem-se às paredes laterais das glândulas calcíferas. Um par de ovários e de funis ovulares situa-se em XIII. Dois pares de espermatecas aproximadamente do mesmo tamanho encontram-se em VIII e IX. As espermatecas (Fig. 45) são longas, claviformes, irregularmente dobradas e sem distinção nítida entre duto e ampola.

\section{CONS:DERAÇÕES}

Holoscolex nemorosus Cognetti, 1904 é conhecido apenas pelo material típico proveniente do Equador, Gualaquiza, redescrito pelo mesmo autor em 1906 (: 235, fig. 58). A nova subespécie separa-se da subespécie nominativa principalmente pela presença de traves pubertais. Seu nome deriva da língua tupi, onde "tacoa" = estrutura pubertal.

\section{Glossodrilus (G.) schubarti, sp. n.} (Fig. 46-49)

\section{MATERIAL}

Brasil, Amazonas: Novo Airăo (ilha do rio $\mathrm{Ne}-$ gro), em solo arenoso, rico em matéria orgânica, 6 exemplares clitelados sem a extremidade posterior (INPAZ$-95)$, I. Ayres, N. Zarghan \& E. Gama col. 27/9/1976.

O maior dos animais fragmentados mede $165 \mathrm{~mm}$ e o número de segmentos é de 260 . $O$ diâmetro na região média do corpo é de $4 \mathrm{~mm}$ em todos os exemplares. Pigmento falta. O segmento I wapresenta-se parcialmente invaginado, formando uma pequena cavidade preoral. No teto desta cavidade, presas ao segmento I, encontram-se duas pequenas dobras de parede delgada, que provavelmente correspondem ao prostômio. A superficie dos segmentos I e II é totalmente sulcada longitudinalmente. Os segmentos III - V têm o anel de cerdas mais elevado; os demais seçmentos são plurianelares, mais os posclitelares, onde se reconhecem até 9 anulos. Uma "zona caudal" aparece como duas áreas retangulares opostas e de superfície rugosa nos espaços aa e $d d$ de $6-7$ segmentos, iniciando-se entre os CLV - CLX. Sua cor é castanha devido ao acúmulo de sangue.

As cerdas dispõem-se em 8 séries longitudinais regulares a partir de III. Têm a forma de um $\mathrm{S}$ alongado, com pequeno nódulo submediano e o quarto apical ornamentado por cicacatrizes transversais curtas e crenuladas. A face convexa, apical é achatada e lisa (Fig. 46 - 47). Na regiăo posclitelar o comprimento e diâmetro médio das cerdas ventrais é de $503 \times 31 \mu \mathrm{m}$ e das laterais $465 \times 31 \mu \mathrm{m}$. As cerdas préclitelares são maiores e mais espessas do que as clitelares. Suas medidas aumentam do segmento III ao $\mathrm{VI}$, onde atingem em média $725 \times 56 \mu \mathrm{m}$, e decrescem para trás até o XIV. As cerdas ventrais de XV - XVII são as maiores de todas, medindo em média $823 \times$ $74 \mu \mathrm{m}$. A relação entre as cerdas nos segmentos XXX - XL de 3 exemplares encontra-se na Tabela 4 .

O clitelo ocupa os segmentos XV - XXIV $[=10)$. É em forma de sela com a margem inferior espessada em XVII - XXIII, pouco lateralmente à série $b$. Um par de traves pubertais estende-se de $1 / 3 \mathrm{XVII}, \mathrm{XVIII}-1 / 2 \mathrm{XXIII}$ em série com $a b$. As traves são de cor branca 
42
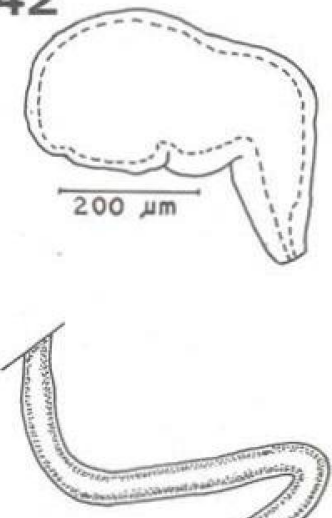

45

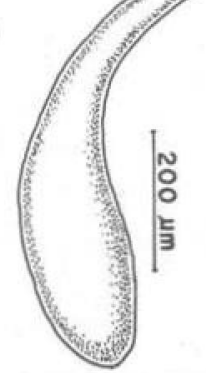

49
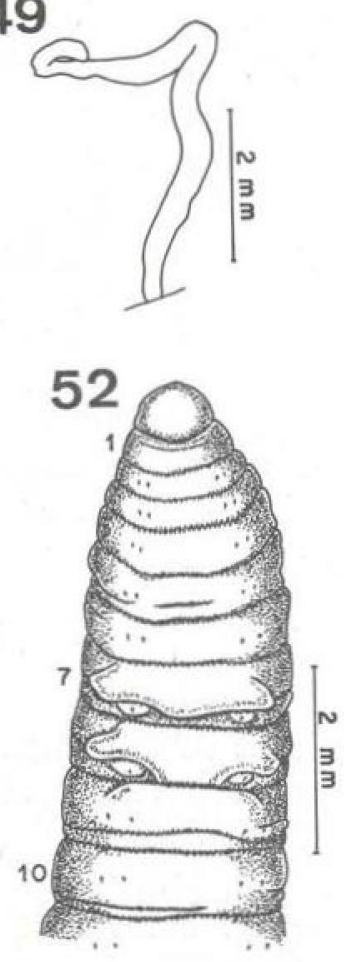

43

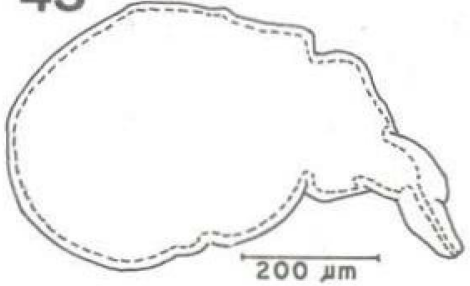

46
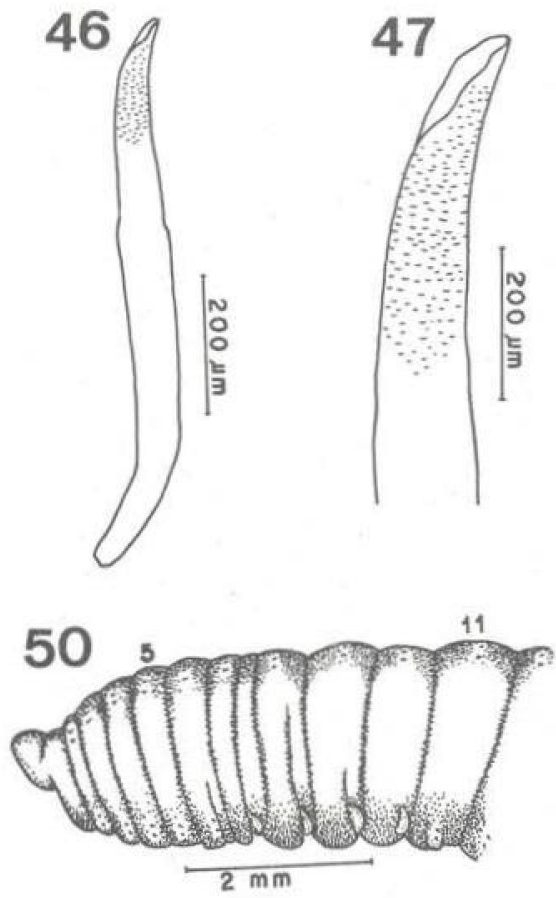

53

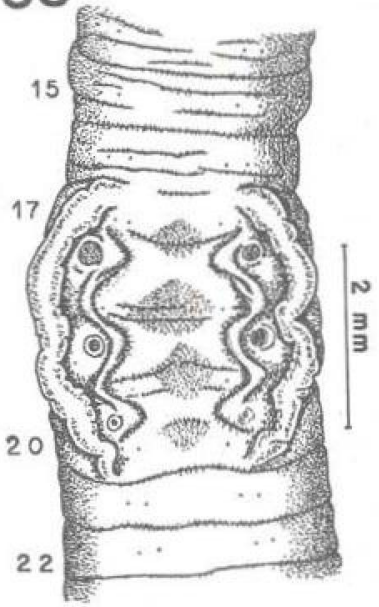

44

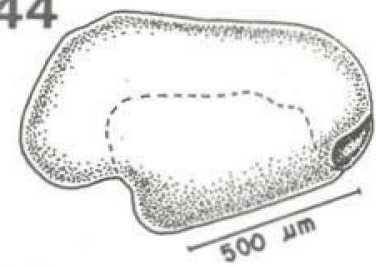

48
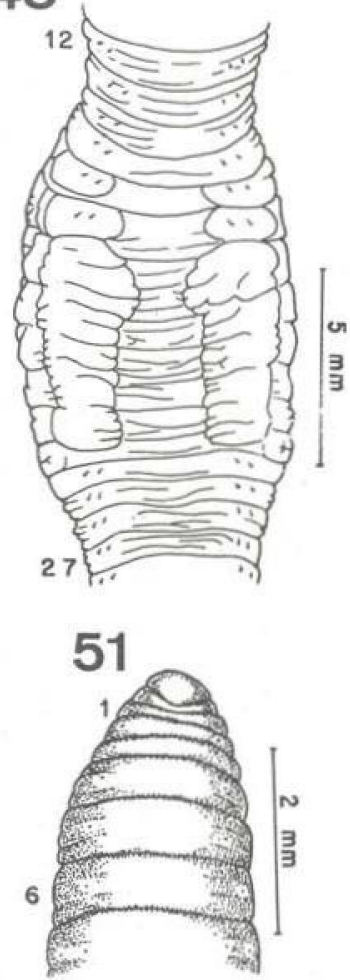

54

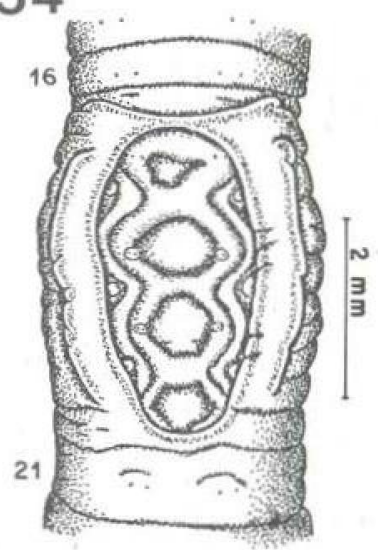

ESTAMPA IV - Holoscolex caramuru Righi, 1975: 42 - espermateca de VIII; 43 - espermateca de IX. Holoscolex nemorosus tacoa, subsp. n.: 44 - glândula calcífera esquerda em vista medial; 45 - espermateca de IX. Glossodrilus (G.) schubarti, sp. n.: 46 - cerda de XVII; 47 - ápice da cerda de XVII; 48 - face ventral dos segmentos XII-XXVII; 49 - espermateca de VIII. Areco reco, gen. n., sp. n.: 50-52 - extremidade anterior em vista lateral, dorsal e ventral; 53 - face ventral dos segmentos XV - XXII; 54 - face ventral dos segmentos XVI - XXI. 
teitosa e mais largas em XVIII. Pares de papi. las volumosas transportam as cerdas $a$ e $b$ de XVI e XVII (Fig. 48). Os poros genitais são microscópicos, reconhecíveis apenas em cortes. O par de poros masculinos localiza-se no terço posterior de XVIII, em série com $a b$, no interior as traves pubertais. O par de poros femininos situa-se imediatamente na frente das cerdas a de XIV. Três pares de poros de espermatecas localizam-se em pequenas papilas arredondadas em série com $c$ nos intersegmentos $7 / 8-9 / 10$.

O primeiro septo visível em dissecação é o 5/6. Os septos $6 / 7-11 / 12$ são espessos, musculosos e alongam-se para trás como cones interpenetrados. Os demais septos são frágeis e dispõem-se mais ou menos transversalmente a partir de $17 / 18$ ou $18 / 19$. Numerosas faixas musculares oblíquas unem as paredes laterais com a ventral na região do ciitelo. Uma moela cilindróide e musculosa localiza-se em VI. O esôfago, talvez devido à fixação e contração dos musculos septais, forma câmaras dorsais em VIII - X. Um par de glândulas calcíferas de estrutura tubular composta situase sobre o esôfago em XII mas, devido ao seu tamanho e forma dos septos, ocupa o espaço correspondente aos segmentos XIV - XVI externos. O curto duto de cada glândula comunica-se com o simétrico antes de abrirem em comum na linha média dorsal do esôfago. Cada glândula tem a forma de um cilíndirico e prolongâ-se posteriormente por uma formação saculiforme, que atravessa os septos seguintes, chegando à cavidade de XVI. As válvulas da transição esôfago-intestino situam-se em XVI. O diâmetro intestinal dilata-se para trás, atingindo o tamanho regular posterior entre $X X V I$ - XXX. O tiflosole inicia-se em XVII; aparece como uma lâmina dorsal, espessa e com a margem livre bifurcada, lembrando em corte transversal um $\mathrm{Y}$ ou $\mathrm{T}$ invertidos.

O vaso dorsal é reconhecível até o segmento VIII. Vaso subneural falta. Pares de corações encontram-se em VIII - XI. Os de VIII - X partem do vaso dorsal e os de XI, que são os mais,volumosos, partem do vaso supraesofágico. Em cada segmento há um par de holonefrídios que se abrem por poros microscópicos em série com as cerdas ventrais.
TABELA 4 - Glossodrilus (G.) schubarti, relaçōes entre as cerdas nos segmentos $\mathrm{XX}-\mathrm{XL}$ de 3 animais.

\begin{tabular}{l|ccccccccc}
\hline \multirow{2}{*}{ Exemplar } & aa & $:$ & $\mathbf{a b}$ & $:$ & $\mathbf{b c}$ & $:$ & $\mathbf{c d}$ & $:$ & dd \\
A & 13,84 & $:$ & 1,00 & $:$ & 2,46 & $:$ & 0,92 & $:$ & 17,23 \\
B & 15,16 & $:$ & 1,00 & $:$ & 2,66 & $:$ & 0,91 & $:$ & 19,33 \\
C & 12,71 & $:$ & 1,00 & $:$ & 2,35 & $:$ & 0,92 & $:$ & 16,28 \\
Média & 13,90 & $:$ & 1,00 & $:$ & 2,49 & $:$ & 0,91 & $:$ & 17,61 \\
\end{tabular}

Um par de testículos e de volumosos funis seminais encontram-se livres em XI, cuja cavidade está cheia de espermatozóides. Um par de vesículas seminais longas estende-se por número variável de segmentos, terminando entre os XXVII - LIII. Em um exemplar as vesículas têm a forma de faixas simples, em outros 3 apresentam ramos ora mais, ora menos longos e que podem subdividir-se. Os dutos seminais correm inicialmente para a frente, acompanhando a inclinação do septo $11 / 12$, até a parede ventral de XII. A seguir, dirigem-se para trás no interior da musculatura longitudinai, pouco abaixo da pleura, até a região posterior de XVIII, onde se abrem. Um par de ovários digitadios situa-se em XIII. O par de ovidutos segue para diante acompanhando a inciinação do septo $13 / 14$ e penetra na muscuiatura parietal no equadior de XIV. Três pares de espermatecas situam-se em VIII - X e são pouco maiores no sentido antero-posterior. As espermatecas estão totaimente cheias de espermatozóides; têm a forma de tubos iongos e irregularmente dobrados, sem distinção entre duto e ampola (Fig. 49) .

CONSIDERAÇõeS

Pela posse de 3 pares de espermatecas em VIiI - X, Glossodrilus (G.) schubarti, sp. n. aproxima-se de G. (G.) marcusae (Righi, 1969), G. (G.) mucupois (Righi, 1970) e G. (G.) tocantinensis (Righi, 1972). Estas espécies são conhecidas apenas da região amazônica e podem ser separadas pela Tabela 5 .

O nome da nova espécie foi dado em homenagem ao Prof. Dr. Herbert O. R. Schubart pela gentil acolhida a um de nós (G. Righi) em seu laboratório no Instituto Nacional de Pesquisas da Amazônia. 
TABELA 5 - Espécies de Glossodrilus Cognetti, 1905 com 3 pares de espermatecas em VIII-X

\begin{tabular}{|c|c|c|c|c|c|}
\hline Glossodrilus & $\begin{array}{l}\text { Comprimen- } \\
\text { to em mm }\end{array}$ & Clitelo & Traves pubertais & $\begin{array}{c}\text { Outras marcas } \\
\text { pubertais }\end{array}$ & $\begin{array}{c}\text { Poros } \\
\text { masculinos }\end{array}$ \\
\hline marcusae & 112 & $1 / 3$ XIII - XXII & $2 / 3$ XVII -XX & $\begin{array}{l}\text { Face ventral de XIV } \\
\text { espessada, com um par } \\
\text { de papilas em ab. }\end{array}$ & XVIII \\
\hline tocantinensis & 132 & $X V=X X I I$ & $1 / 2 X V I I-1 / 2 X X$ & $\begin{array}{l}\text { Papila média ventral } \\
\text { em XXI. }\end{array}$ & XVIII \\
\hline schubarti & 165 & $X V-X X I V$ & $\begin{array}{l}1 / 3 \text { XVII, XVIII = } \\
1 / 2 \text { XXIII }\end{array}$ & $\begin{array}{l}\text { Pares de papilas em } \\
\text { ab de XVI e XVII. }\end{array}$ & XVIII \\
\hline mucupois & $43-47$ & $1 / 2 X V-X X I$ & $1 / 3,1 / 2 X V 1=X \mid X$ & Faltam & $16 / 17$ \\
\hline
\end{tabular}

\section{SPARGANOPHILIDAE ?}

Areco, gen. n.

\section{DIAGNOSE}

Corpo de seção quadrangular, com sulco dorsal posclitelar. Cerdas intimamente pareadas, dispostas em 4 pares de séries longitudinais. Esôfago longo, sem moela anterior mas, posteriormente, com a parede espessada, musculosa. Glândulas calcíferas faltam. Um par de nefrídios por segmento. Bexiga nefridial falta. Testículos e funis seminais livres em XI. Vesículas seminais presentes. Próstatas e câmaras copulatórias ausentes. Um par de poros masculinos intraclitelares. Ovários em XIII. Espermatecas pretesticulares, salientes na cavidade do corpo.

TIPO DO GÊNERO

Areco reco, sp. n.

CONSIDERAÇõES

Com base nos sistemas conhecidos das Lumbricoidea (Michaelsen, 1918; 1928b; Stephenson, 1930; Omodeo, 1956; Gates, 1959; Jamieson, 1971), não foi possível estabelecer a exata posição de Areco, gen. n.. Pela forma do corpo e organização do tubo digestivo, o novo gênero aproxima-se de Drilocrius, especialmente de $D$. ehrhardti Michaelsen, 1926, da família Microchaetidae segundo Michaelsen (1928b: 107). Jamieson (1971: 801) considera $D$. ehrhardti como tipo do então novo gênero, Glyphidrilocrius, das Glossoscolecidae, Alminae. Pela posição pretesticular das espermatecas, Areco aproxima-se de Sparganophilus, pertencente às Sparganophilidae. Areco distingue-se de Drilocrius, Glyphidrilocrius e Sparganophilus, entre vários outros caracteres, por ser metândrico e os demais holândricos. Assim, a inclusão do novo gênero entre as Sparganophilidae é duvidosa.

\section{Areco reco, $\mathrm{sp} . \mathrm{n}$.}

(Fig. $50-60$ )

MATERIAL

Brasil, Amazonas : Estrada Manaus-Itacoatiara, Km (Reserva Ducke), em solo úmido próximo a um igarapé, 4 exemplares ( 3 clitelados) sem a extremidade posterior (INPAZ-83A-D), E. F. Nascimento col. 9/5/1975.

O comprimento do maior dos exemplares fragmentados é de $90 \mathrm{~mm}$. O diâmetro pouco após o clitelo varia de $3,3-4,1 \mathrm{~mm}$. Pigmento falta. O número de segmentos do maior exem- 
plar é 191. O corpo é de seção quadrangular, com as cerdas partindo dos ângulos. A partir da região compreendida entre os segmentos XLV - LV, aparece uma depressão mediana dorsal, que se aprofunda para trás. Em dois exemplares encontram-se poros dorsais esporádicos em alguns intersegmentos posclitelares, faltam nos preclitelares. Em um exemplar, todos os intersegmentos posclitelares apresentam poros dorsais e nos preclitelares apenas o 11/12. O prostômio é do tipo proepilobo (Fig. 50 - 51). O primeiro segmento apresenta-se em 3 exemplares subdividido por 1 ou 2 sulcos transversais profundos em 2 ou 3 anulos, o que dificultou a contagem dos segmentos. A numeração dos segmentos que seguimos baseouse em um exemplar onde o primeiro segmento não está sulcado ventralmente (Fig. 50 e 52) e foi possível situar os testículos e funis seminais no segmento $\mathrm{XI}$.

Nos animais clitelados, a metade anterior da face ventral dos segmentos VII - IX (2 exemplares) ou VII . X (1 exemplar é espessada e eleva-se mais na linha das cerdas $a b$, deixando uma depressão posterior. Em cada uma dessas depressões de VII e VIII (2 exemplares) ou VII - X ( 1 exemplar) encontra-se uma papila arredondada, de onde emerge uma cerda copulatório. O clitelo ocupa os segmentos $1 / 2 \mathrm{XVI}$, XVII - XXII ( $=6,5$ ou 6 segmentos). É anelar em XXI e XXII e apresenta uma área diferenciada ventral em XVII - XX. Esta área, de contorno quadrangular, é limitada laterailmente pelas margens espessas e elevadas do clitelo, que podem apresentar-se totalmente abertas ou parcialmente contraídas (Fig. 53 - 55). Um par de traves pubertais estende-se de $1 / 2$ $X V I I-1 / 2 X X$. Tem a forma de faixas em ziguezague, pouco espessas e sailientes, com os ângulos de ápice laterai envolvendo as cerdas ventrais e os de ápice medial nos intersegmentos. $\mathrm{Em}$ dois animais os ângulos mediais das traves pubertais são unidos entre si por pequenas faixas transversais salientes, isolando no conjunto 4 áreas losangulares medianas. Em um animal estas faixas transversais estão mal definidas. Nos intersegmentos 17/18, 18/19 e $19 / 20$, entre as traves pubertais e as margens do clitelo, encontram-se 3 pares de papilas pubertais cônicas e crateriformes, constituídas por células glandulares cilíndricas, altas, re- vestidas por uma capa muscular e algo salientes na cavidade do corpo. Os poros genitais são microscópicos, só reconheciveis em cortes.

As cerdas dispõem-se em 4 pares de séries longitudinais regulares a partir do segmento II. As cerdas normais têm a forma de um $\mathrm{S}$ alongado, com pequeno nódulo no início do terço apical (Fig. 56). Uma pequena porção subapical das cerdas, correspondendo a aproximadamente $1 / 10$ do seu comprimento, é ornamentada por pequenas cicatrizes transversais de bordo crenulado e dispostas irregularmente. No clitelo as cerdas são semelhantes. Na região dos segmentos $\mathrm{XL}$ - $\mathrm{L}$, o comprimento das cerdas ventrais varia de $337-412 \mu \mathrm{m}$, em média $378 \mu \mathrm{m}$ e o das laterais de $381-462$ $\mu \mathrm{m}$, em média $431 \mu \mathrm{m}$. Em dois animais, as relações entre as cerdas nos segmentos $X X X$. $\mathrm{XL}$ são $a a: a b: b c: c d: d d=8,40: 1,00:$ $9,73: 1,23: 10,80=8,50: 1,00: 10,40: 1,26:$ 10,66. Nos segmentos VII e VIII (1 exemplar), VII - IX (2 exemplares) ou VII - X (1 exempiar) há uma única cerda ventral de cada lado e transformada em cerda copulatória. As cerdas copulatórias são, em sua maior porção, quase retas, com a extremidade ental curva. Seus $2 / 10$ subapicais são ornamentados por cicatrizes semilunares, abertas para o ápice (Fig. 57). As cicatrizes dispõem-se irregularmente na maioria das cerdas. Das 10 cerdas observadas, apenas 2 apresentam, na porção mais apical, as cicatrizes dispostas em 4 séries alternas, perdendo a regularidade na porção basal. O comprimento destas cerdas varia de 537 . $644 \mu \mathrm{m}$, em média $587 \mu \mathrm{m}$. Sua maior largura situa-se na regiăo submediana e varia de 81 . $100 \mu \mathrm{m}$, em média $88 \mu \mathrm{m}$. Associadas a cada cerda copulatória há uma ou duas glandulas tubulares volumosas, salientes na cavidade do corpo e que se abrem na porção ectal do folículo setígero.

Os septos são transversais, de espessura semelhante e reconhecíveis a partir de 5/6. O esôfago é delgado e mais ou menos moniliforme a partir de $V$; apresenta-se dilatado na região dos segmentos XXVIII, XXX - XXXII, como uma espécie de papo, Em XXXIII - XXXVII seu diâmetro equivale a cerca de $2 / 3$ do das porções adjacentes e a parede é espessa e muscular, mais em XXXIV-XXXVI. Após esta 
porção musculosa inicia-se o intestino que, a partir do segmento $\mathrm{XL}$, apresenta um tiflosole mediano dorsal e ondulado. Glândulas calcíferas extra ou intramurais faltam. Do aparelho circulatório foi possivel reconhecer corações moniliformes nos segmentos VIII - XI. Vaso subneural falta. Os nefrídios são largos, lobulados e em número de um par por segmento a partir de VI. Bexiga nefridial falta. Funis, dutos e poros nefridiais não foram encontrados. Nos nefrídios só foi possível observar pequenos e esparsos canalículos, aparentemente intracelulares.

Um par de testículos e de funis seminais iridescentes encontram-se livres no segmento $\mathrm{XI}$, cuja cavidade esta repleta de espermatozóides. O par de canais deferentes é ligeiramente ondulado e estende-se ao lado das cerdas $b$, imediatamente acima da musculatura parietal, até o segmento XVII. Cada canal penetra agora na parede do corpo, atravessa a porção glandular do primeiro par de papilas pubertais e vai abrir-se na superfície logo após estas papilas, em $1 / 2 \mathrm{XVIII}$, entre as traves pubertais e a margem do clitelo. Um par de vesículas seminais saquiformes situa-se dos lados do esôfago nos segmentos XII - XIII, XV. Um par de ovários flabelares prende-se à face posterior e ventral de $12 / 13$. O par de curtos ovidutos abre-se na parte anterior do segmento XIV, na depressão de $13 / 14$, imediatamente ao lado da série de cerdas $b$. Em 3 animais há um par de espermatecas em cada segmento de VII - IX; em um único animal há outro par de espermatecas em X. Seus poros situam-se em 6/7 - 8/9, 9/10 em série com as cerdas ventrais. As espermatecas são saculiformes, salientes na cavidade do corpo, com a porção apical mais ou menos dobrada e sem distinção entre duto e ampola (Fig. 58 - 60). Em cada espermateca a parede é espessa, mais na porção ectal, onde se formam reentrancias irregulares, sem constituir câmaras seminais definidas. Nestas reentrancias encontram-se numerosos espermatozóides, poucos no lúmen da espermateca.

O nome do novo gênero e espécie provém da língua tupi, onde "arecoreco" = mistura.

\section{OCNERODRILIDAE}

Eukerria guamais Righi, 1971

Eukerria guamais Righi, 1971b: 2, figs. 1-3.

\section{MATERIAL}

Brasil, Amazonas : Estrada Manaus-Itacoatiara, Km 26 (Reserva Ducke), margem do igarapé do Barro Branco, próximo a um chiqueiro, em solo periodicamente inundado, 1 exemplar clitelado (INPAZ-72), L. Antony \& G. Righi col. 23/6/1975.

A espécie era conhecida apenas da localidade tipo, Pará: Belém. O animal do Amazonas é ligeiramente maior, atingindo $30 \mathrm{~mm}$ de comprimento e tem 78 segmentos. Suas próstatas diminutas restringem-se aos segmentos XVII e XIX. As glândulas calcíferas são do tipo gordiodrilóide (Righi, 1968a: 170), com lúmen central pequeno, donde partem numerosos canalículos que se ramificam e correm longitudinalmente na parede espessa das glândulas . Revendo o material típico da espécie, verificamos que a estrutura destas glândulas é como descrita acima e não do tipo ocnerodrilóide como foi apresentada (Righi, 1971b: 2).

\section{Haplodrilus Eisen, 1900}

Ocnerodrilus (part.), Rosa, 1895: 3; 1896a: 147; Cognetti, $1900: 3$.

Ocnerodrilus (Haplodrilus) Eisen, 1900: 112; Cognetti, 1905b: 55, Michaelsen, 1900b: 384 .

Haplodrilus, Michaelsen, $1926: 321 ; 1927: 370$; Stephenson, $1930: 860$.

Gatesia Jamieson, $1962: 617$.

DIAGNOSE

Cerdas dispostas em 4 pares de séries longitudinais. Prostômio epilobo. Um par de poros masculinos e prostáticos combinados em XVII. Poros das espermatecas em $7 / 8$ ou $8 / 9$. Poros dorsais ausentes. Moela presente em VII ou ausente. Um par de glândulas calciferas em IX. Último par de corações em XI. Holonefridial. Testículos e funis seminais em $X$. Um par de próstatas tubulares em XVII. Espermatecas em VIII ou IX. sem divertículos.

\section{TIPO DO GÊNERO}

Ocnerodrilus borelli Rosa, 1895, por designação original. 


\section{CONSIDERAÇÕES}

gênero monotípico Gatesia, como foi definido, difere de Haplodrilus "sensu" Stephenson (1930: 860) pela posição mais anterior dos poros das espermatecas e pela presença de uma moela em VII, agora encontrada em $H$. tagua, sp. n.. Assim, resta para separar os dois gêneros a posição das aberturas das espermatecas. Este caracter não é suficiente para conferir valor genérico a Gatesia, que consideramos como subgênero de Haplodrilus. Segue-se a diagnose dos subgêneros e a lista das espécies com sua distribuição geográfica.

\section{Subgênero Haplodrilus s.s.}

\section{DIAGNOSE}

Um par de poros de espermatecas em $8 / 9$.

H. (H.) borelli (Rosa, 1895) - Paraguai : Assunção (Rosa, 1895: 3; 1896: 147, fig. 22).

H. (H.) michaelseni (Cognetti, 1900) - Paraguai : Assunçắo. Brasil, Mato Grosso: Urucum, próximo de Corumbá (Cognetti, 1900: 3, fig. 5; 1905: 55).

H. (H.) iheringi Michaelsen, 1926 - Brasil, Sẫo Paulo : Piracicaba (Michaelsen, 1926: 321, fig. K).

H. (H.) tagua, sp. n. - Brasil, Amazonas: Sucunduri. Subgênero Gatesia Jamieson, 1962

\section{DIAGNOSE}

Poro (s?) de espermateca (s ) em $7 / 8$.

H. (G.) unica Jamieson, 1962 - Argentina : Loreto (Jamieson, 1962: 619, fig. 4).

Haplodrilus (H.) tagua, sp. n. (Fig. 61-66)

\section{MATERIAL}

Brasil, Amazonas : Sucunduri (próximo à confluência da estrada Transamazônica com o rio Sucunduri), em troncos podres no igarapé da Caixa d'Água, 3 exemplares clitelados e 3 maduros aclitelados (INPAZ-87), L. Antony, E. Rufino \& G. Righi col. 26/6/1975. Estrada Transamazônica, trecho Humaitá-Jacaréacanga, $\mathrm{Km} 523$, em troncos podres junto a um igarapé, 7 exemplares clitelados (INPAZ-92), L. Antony, E. Rufino, E. Froehlich \& G. Righi col. 28/6/1975.

O comprimento dos animais varia de 25 - $35 \mathrm{~mm}$ e o diâmetro na região mediana do corpo é de $0,6 \mathrm{~mm}$ em todos os clitelados.
Nos animais fixados a cor geral do corpo é laranja clara, semelhante à do $n .^{\circ} 200$ de Séguy (1936), provavelmente devida ao conteúdo in. testinal. O número de segmentos varia de 95 . 111. O prostômio (Fig. 61) é do tipo epilobo aberto. O clitelo é em forma de sela nos segmentos XIV - 1/2 XIX $(=5,5)$. Sua margem inferior dispõe-se na linha das cerdas a e salienta-se da porção mediana ventral de $1 / 2$ XIV - $1 / 2$ XIX, mais em XV - XVIII. A face ventral de XVII é espessada em forma de hexagono, no interior do qual salientam-se duas formaçōes mamilares volumosas, separadas por um curto sulco longitudinal mediano (Fig. 62) . $\mathrm{O}$ ápice das formações mamilares situa-se em série com $b$ e nele abrem-se em comum os poros masculinos e prostáticos. Os poros femininos estão no terço anterior de XIV, em série com b. Apresentam-se como pequena fenda transversal, circundada por delgada faixa es: branquiçada. Um par de poros de espermatecas pouco evidentes, encontra-se em $8 / 9$, na linha de $a b$. Poros dorsais faltam. As cerdas dispôem-se em 8 séries regulares a partir de II; faltam as ventrais de XVII. As cerdas săo quase retas, com as extremidades curvas e um pequeno nódulo no início do terço distal (Fig. 63) . Seu comprimento médio, na região mediana do corpo, é de $120 \mu \mathrm{m}$. Na região dos segmentos $\mathrm{XXX}$ - XL, a relação entre as cerdas é aa $: a b: b c: c d: d d=5,00: 1,00: 4,33: 1,12:$ 7,50 .

Os septos $6 / 7$ - 9/10 são pouco mais espessos do que os demais. Em VII encontra-se uma moela em forma de cilindro curto, musculoso e quase duas vezes mais volumoso do que o restante do esôfago. Um par de glândulas calcíferas abre-se lateralmente no esôfago, na região posterior do segmento IX. Estas glândulas são piriformes e volumosas, ocupando quase toda a extensão do segmento, prendendo-se seu bordo anterior, cego, no septo $8 / 9$ por uma faixa conjuntiva. As glândulas são formadas por uma parede espessa e um peque. no lúmen central ciliado, de onde partem numerosos canalículos delgados (Fig. 64). Os canalículos ramificam-se na parede da glândula, formando um sistema complexo, entremeado por numerosos espaços sanguíneos radiais e longitudinais. O intestino inicia-se em XII e em XIII já apresenta o diâmetro normal poste- 


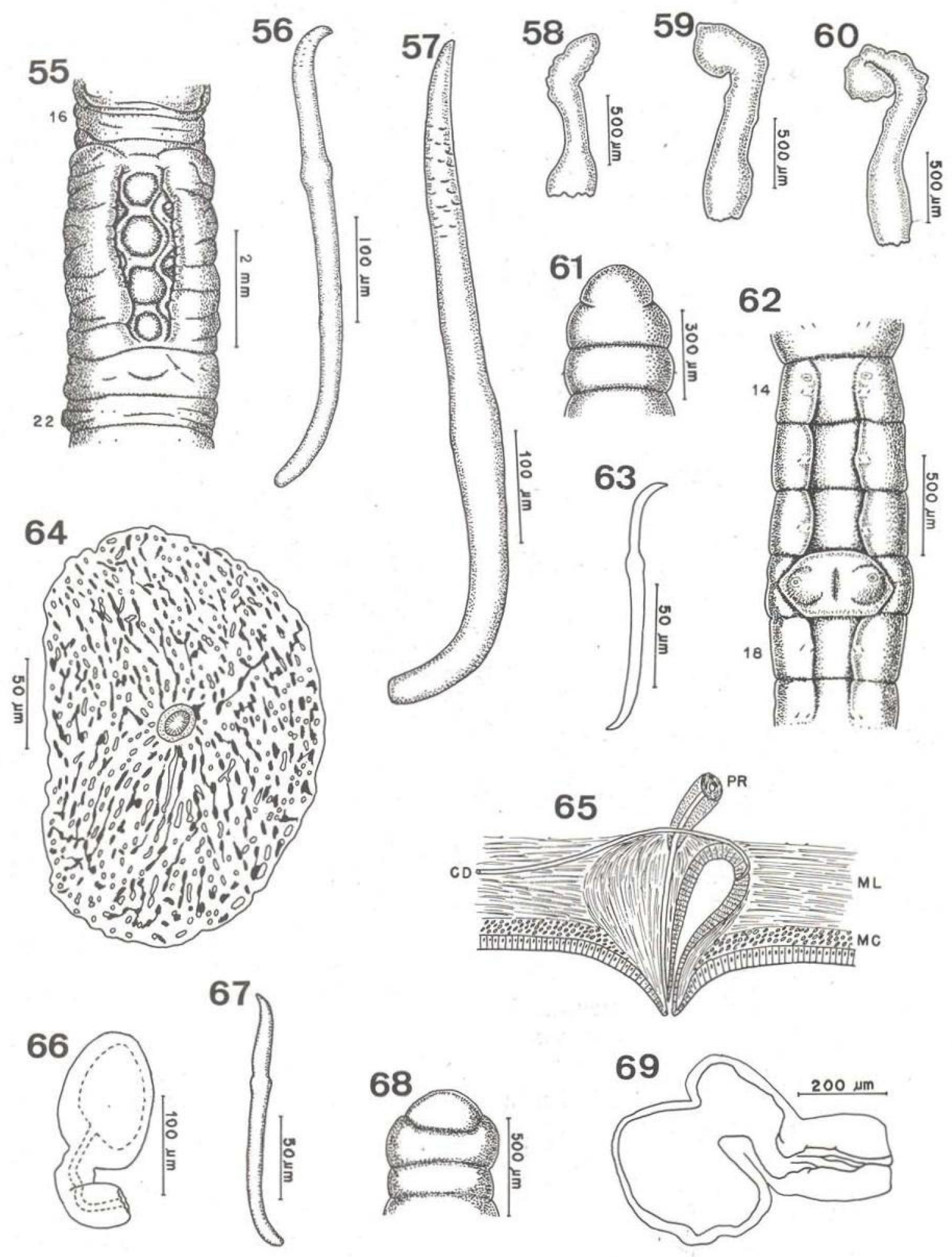

ESTAMPA V - Areco reco, gen. n., sp. n.: 55 - face ventral dos segmentos XVI-XXII; 56 - cerda ventral mediana; 57 - cerda copulatória de IX; 58-60 - espermateca de VII-IX. Haplodrilus (H.) tagua, sp. n.: 61 extremidade anterior em vista dorsal; 62 - face ventral dos segmentos XIV-XVIII; 63 - cerda ventral mediana; 64 - corte transversal mediano da glândula calcífera; 65 - esquema da parte terminal das vias masculinas reconstruido de cortes seriados; 66 - espermateca de IX. Dariodrilus ferrarius, gen. $\mathrm{n}$., $\mathrm{sp}$. n.: 67 - cerda da regiăo mediana; 68 - extremidade anterior em vista dorsal; 69 - espermateca de $I X$. $(C D=$ canal deferente; $\mathrm{MC}=$ musculatura circular; $\mathrm{ML}=$ musculatura longitudi nal; $\mathrm{PR}=$ próstata. ) 
rior. Tiflosole e cecos intestinais faltam. Dois pares de corações volumosos encontram-se em $\mathrm{X}$ e XI. Em cada segmento há um par de holonefrídios.

Um par de testículos e de funis seminais encontram-se livres na cavidade do segmento $X$, que está repleta de espermatozóides. O par de canais deferentes é retilíneo e corre ao lado da série de cerdas $b$, no interior da musculatura longitudinal. Um par de vesículas seminais profundamente lobuladas situa-se em XI. Do par de próstatas, o duto delgado restringe-se ao segmento XVII e a porção glandular, tubular, estende-se ao lado da cadeia nervosa até o segmento XIX, onde a porçăo terminal faz algumas voltas irregulares. Cada papila mamilar de XVII corresponde internamente a uma formação muscular piriforme (Fig. 65), em cuja porção posterior se associa uma câmara constituída por células altas e de aspecto glandular, onde abre-se posteriormente o canal deferente (CD). A câmara continua-se por um duto que atravessa a formação muscular e recebe, na porção mais ectal, o duto da próstata (PR), abrindo-se por um poro comum no ápice da papila. Um par de ovários encontra-se em XIII) e um par de espermatecas diminutas em IX. Em cada espermateca (Fig. 66) a ampola é ovóide e bem separada do duto, que é curvo e pouco mais longo do que a ampola.

\section{CONSIDERAÇÕES}

Pela posse de uma moela bem diferenciada em VII, Haplodrilus (H.) tagua separa-se das demais espécies do subgênero. Outros caracteres diferenciais são a forma das espermatecas e do poróforo masculino.

O nome a nova espécie deriva da língua tupi e significa "amarelo".

\section{Dariodrilus, gen. $\mathrm{n}$.}

\section{DIAGNOSE}

Cerdas 8 por segmento. Um par de poros masculinos e prostáticos em XVII. Dois pares de poros femininos em XIII e XIV. Aberturas dàs-espermatecas par em $8 / 9$. Moela rudimentar em VII. Um par de glândulas calcíferas em IX, com a parede espessa percorrida por cana- lículos longitudinais e delgado lúmen central. Dois pares de testículos em $\mathrm{X}$ e XI. Dois pares de ovários em XII e XIII. Um par de espermatecas sem divertículos em IX. Poros dorsais faltam.

TIPO DO GÊNERO

Dariodrilus ferrarius, sp. $\mathrm{n}$.

\section{CONSIDERAÇÕES}

Pela sua organização geral, Dariodrilus aproxima-se de Ocnerodrilus (Iliogenia). Por ser hologínico, Dariodrilus separa-se deste e dos demais gêneros das Ocnerodrilidae, que são metagínicos (Gates, 1966: 51; 1972: 262).

\section{Dariodrilus ferrarius, $\mathrm{sp} . \mathrm{n}$.} (Fig. 67 - 71)

\section{MATERIAL}

Brasil, Amazonas : Secunduri (Estrada Transamazônica, trecho Humaitá-Jacaréacanga, Km 523), em troncos podres junto a um igarapé, 6 exemplares clitelados (2 sem a extremidade posterior) (INPAZ-88), L. Antony, E. Rufino, E. Frohelich \& G. Righi col. 28/6/1976.

O comprimento dos animais varia de $35-50 \mathrm{~mm}$, em média $41 \mathrm{~mm}$ e o diâmetro, na região mediana do corpo, de 0,67-0,78 mm. em média $0,74 \mathrm{~mm}$. O prostômio (Fig. 66) é largo, semicircular e com uma língua ampla e fechada, que penetra $1 / 3$ no peristômio. O número de segmentos varia de 102 - 157, em média 130. Pigmento e poros dorsais faltam. As cerdas são em número de 4 pares por segmento a partir de II; faltam as ventrais de XVII. As cerdas são lisas e quase retas, com ligeira curvatura nas extremidades e um pequeno espassamento no início do terço distal (Fig, 67). $\mathrm{Na}$ região mediana do corpo o comprimento das cerdas varia de $135-160 \mu \mathrm{m}$, em média $146 \mu \mathrm{m}$. Entre os segmentos XXX - XXXV, a relação entre as cerdas em dois animais é aa : $a b: b c: c d: d d=2,00: 1,00: 2,73: 0,92:$ $6,38=2,50: 1,00: 3,34: 1,11: 7,72$.

O clitelo é em forma de sela, com o limite inferior pouco lateral à série $b$, nos segmentos XIII - XVIII $(=6)$. A face ventral, entre as cerdas de XIV e XV e entre as de XV e XVI, é espessada e de contorno quadrangular (Fig. 71) . Uma depressão arredondada situa-se ventral- 

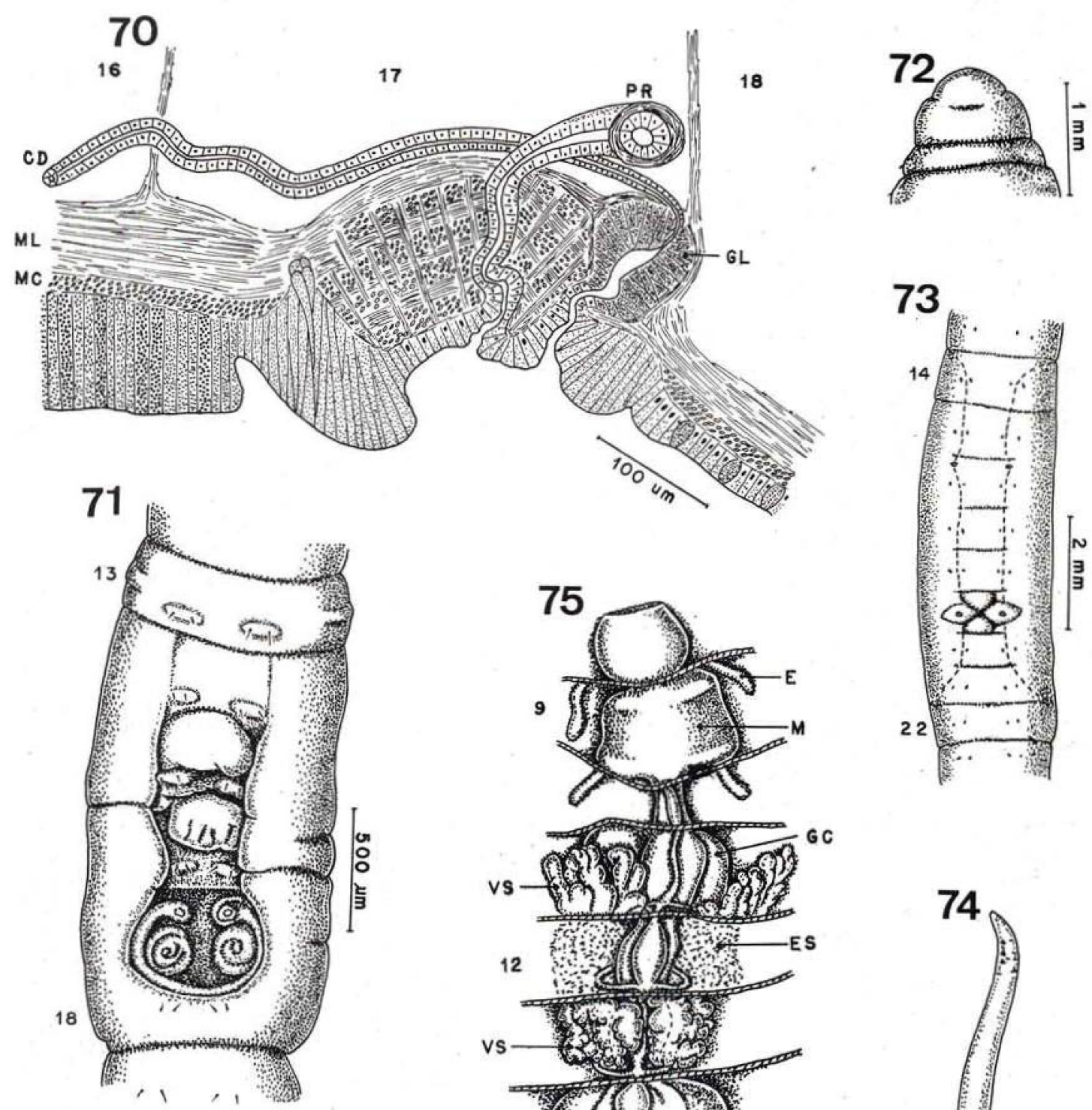

\section{6}
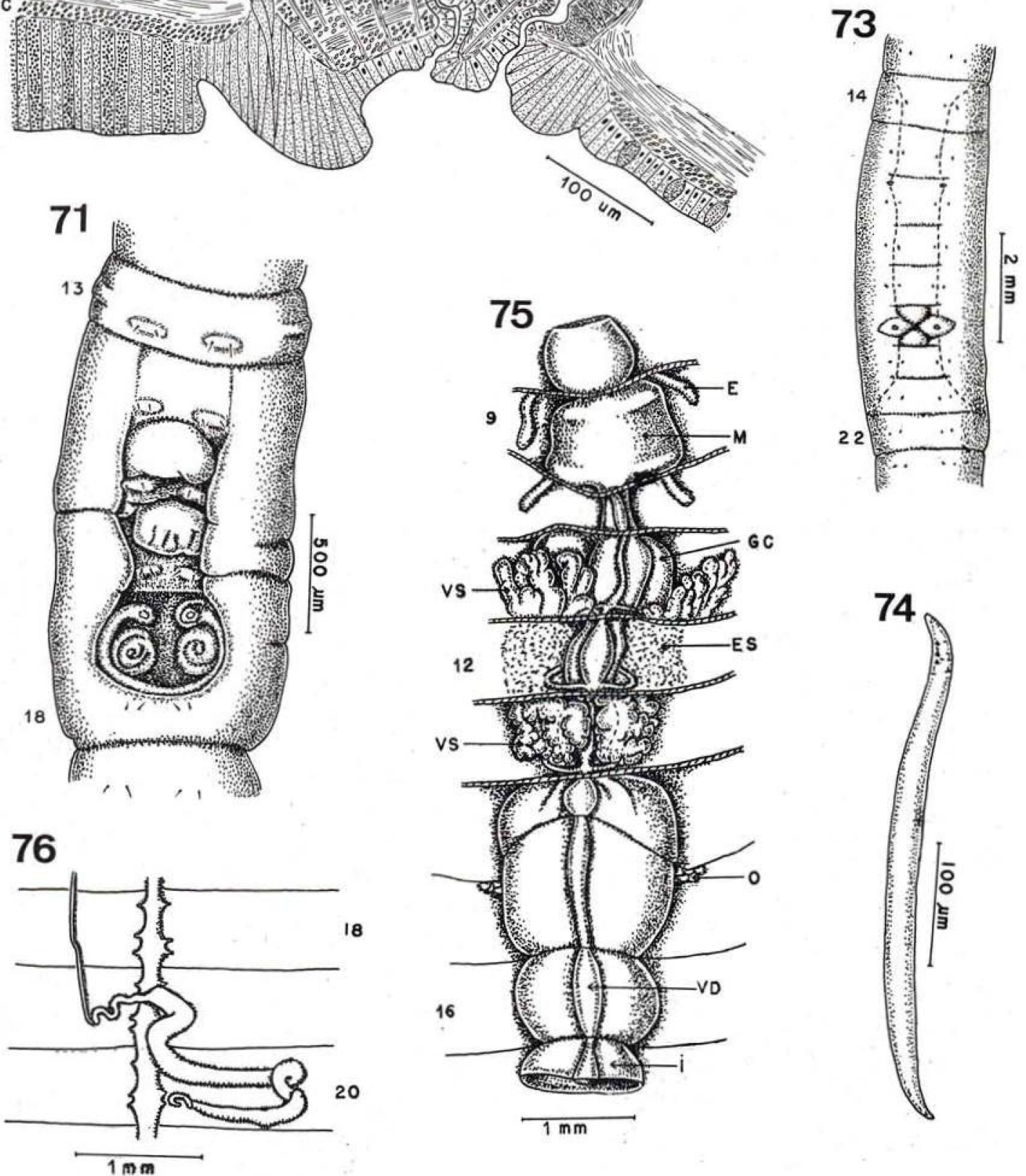

ESTAMPA VI - Dariodrilus ferrarius, gen. n., sp. n.: $70-$ corte sagital das aberturas masculinas; 71 - face ventral dos segmentos XIII-XVIII. Exisdrilus rarus, gen. n., sp. n.: 72 - extremidade anterior em vista dorsal; 73 - face ventral dos segmentos XIV - XXII; 74 - cerda ventral mediana; 75 - tubo digestivo e órgãos genitais pos segmentos $\mathrm{IX}-\mathrm{XV} \mathrm{X} ; 76$ - próstata e canal de ferente esquerdos. $\quad(\mathrm{CD}=$ canal deferente; $\mathrm{E}=$ espermateca; $\mathrm{ES}=$ espermatozóides; $\mathrm{GC}=$ glândula calcifera; $\mathrm{GL}=$ glândula; $\mathrm{M}=$ moela; $\mathrm{MC}=$ musculatura circular; $\mathrm{ML}=$ musculatura longitudinal; $\mathrm{O}=$ ovário; $\mathrm{PR}=$ próstata; $\mathrm{VD}=$ vaso dorsal; $\mathrm{VS}=$ vesícula seminal.) 
mente em XVII - 1/2 XVIII; sua margem interna é acompanhada por uma faixa espessada em forma de ferradura. As duas extremidades desta faixa são anteriores na depressão, pouco mais largas e com uma área glandular central. Imediatamente atrás destas estruturas e no interior da depressão situam-se duas papilas volumosas percorridas por t:m sulco mais ou menos helicoidal. No ápice destas papilas encontram-se os microscópicos poros masculinos. Um par de poros prostáticos, também microscópicos, situam-se entre as papilas e a margem anterior da faixa $\mathrm{cm}$ ferradura. Dois pares de poros femininos, só reconhecíveis em cortes, abrem-se no terço anterior dos segmentos XIII e XIV, em série com $a b$. Um par de poros de espermatecas situa-se em papilas arredondadas em $9 / 10$, na linha das cerdas ventrais.

O primeiro septo é o $5 / 6$. O esôfago apresenta-se dilatado em VII, onde seu diâmetro é cerca de 1,5 vezes maior do que em IX; por vezes apresenta-se dilatado também em VIII. Em VII, os quartos anterior e posterior do esôfago têm estrutura semelhante à encontrada nos demais segmentos. Os $2 / 4$ medianos apresentam uma espessa capa de musculatura circular, constituindo uma moela rudimentar. Um par de glândulas calcíferas situa-se sob o esôfago em IX. Cada glândula é piriforme, com a extremidade afilada anterior. Compóe-se de uma parede espessa e de um delgado lúmen central ciliado e de contorno circular, que a percorre longitudinalmente e abre-se, por curto pedúnculo perpendicular, na regiăo ventro-lateral e posterior do esôfago. Na região mediana das glândulas seu diâmetro médio é de $170 \mu \mathrm{m}$ e o do lúmen $20 \mu \mathrm{m}$. Na parede encontram-se canalículos longitudinais intercomunicantes, cujo diâmetro varia de $4-6 \mu \mathrm{m}$, entremeados com uma rica rede vascular, onde predominam vasos longitudinais. O intestino inicia-se em XIII; cecos e tifiosole faltam.

O aparelho excretor compõe-se de um par de holonefrídios por segmento. Três pares ds corações encontram-se em X - XII. Vaso subneural falta. Dois pares de testículos e de funis seminais encontram-se em X e XI, cujas cavidades, principalmente a de $X$, estão repletás de espermatozóides. Vesículas seminais profundamente lobuladas situam-se em IX, XI e XII; as de XI são as mais volumosas e as de $\mathrm{IX}$ as menores. Os dois canais deferentes de cada lado fundem-se na região posterior de XII ou em XIII, resultando um canal único, que corre imediatamente acima da parede do corpo, apresentando o mesmo calibre em toda a extensão. A musculatura da parede do corpo espessa-se na região das aberturas masculinas e prostáticas, formando dois pequenos nódulos salientes nos $2 / 3$ posteriores da cavidade de XVII. Na região mediana de cada nódulo penetra um duto de próstata (Fig. 70, PR) e na região posterior encontra-se uma volumosa glândula piriforme $(G L)$, envolvida por uma capa muscular, onde penetra o canal deferente (CD). As próstatas dirigem-se para trás sob o intestino, seguindo uma trajetória retilínea ou pouco ondulada. O duto é musculoso, seu diâmetro equivale a $1 / 3$ do da porção glandular e seu comprimento varia de 1 a 2,5 segmentos. A porção glandular é tubular, inicia-se entre $1 / 2$ $X V I I I$ - XX e chega a atingir o segmento XXVI. $O$ par de glândulas associadas à porção terminal dos canais deferentes talvez corresponda ao segundo par de próstatas modificado.

Dois pares de ovários e de funis ovulares situam-se em XII e XIII. Nos dois animais seccionados foram encontrados ovos maduros apenas no segundo par de ovários. Um par de espermatecas volumosas e repletas de espermatozóides encontra-se em IX. Em cada espermateca (Fig. 69) o duto é espesso e musculoso; seu comprimento equivale a metade do da ampola, que normalmente apresenta-se dobrada. Divertículos faltam.

\section{ANOMALIAS}

Dos 6 exemplares estudados, 3, designados abaixo por A, B e C, apresentaram-se irregulares. Em A o segmento IX tem 2 pares de cerdas $a$ e $b$ e um par de $c$ e $d$. Em B os poros masculinos e prostáticos situam-se externamente em XVI mas, internamente em XVII. Isto porque em $1 / 2$ XIV há um septo transversal dividindo sua cavidade em duas. Em C todas as estruturas externas e internas, a partir das que estariam originalmente em VII, estão deslocadas dois segmentos para trás. Ainda neste animal, além do par de espermatecas em $\mathrm{XI}$, há uma impar, esquerda e de igual desenvolvímento em $\mathrm{X}$. 
Exisdrilus, gen. $\mathrm{n}$.

\section{DIAGNOSE}

Cerdas dispostas em 8 séries longitudinais. Um par de poros masculinos e prostáticos combinados em XIX. Poros dorsais ausentes. Poros das espermatecas em 5/6 - 9/10 (caracter genérico?). Moela presente em IX. Um par de glândulas calcíferas em XI. Três pares de corações em XI - XIII. Holonefridial. Testículos e funis seminais livres em XII. Um par de próstatas tubulares em XIX. Um par de ovários em XV. Espermatecas em VI - X sem divertículos.

\section{TIPO DO GÊNERO}

\section{Exisdrilus rarus, $\mathrm{sp} . \mathrm{n}$.}

\section{CONSIDERAÇÕES}

Pela posição mais posterior dos diferentes órgãos, Exisdrilus afasta-se dos demais gêneros de Ocnerodrilidae. A exata posição segmentar dos órgãos ao longo do eixo antero-posterior é de grande importância na sistemática e filogênese dos Oligochaeta. Erros de localização ocorrem devidos a dois fatores: 1 anelação secundária aliada a dificuldade na observação de cerdas ou mesmo seu desaparecimento; 2 - forma e inserção dos septos, que nem sempre se prendem nos intersegmentos correspondentes, diferindo a segmentação externa da interna. Estes casos não se aplicam em $E$. rarus, onde os segmentos são simples e os septos regulares.

Considerando que a posição dos ovários no segmento XIII é a regra nos Megadrile e que em E. rarus situam-se em XV, verificamos que todos os órgãos, a partir da moela, estão deslocados dois segmentos para trás. Abstraindose a existência dos segmentos VI e VII, de modo que a moela e os órgãos seguintes se localizassem dois segmentos para diante, $E$. rarus seria uma espécie de Haplodrilus como definido acima, porém distinta das demais pelo tamanho e por ter 5 pares de espermatecas. A existência de dois segmentos a mais poderia ser explicada por uma regeneração hipermérica. Contudo, não observamos em nosso material qualquer indício de ter havido regenera- ção. O fenômeno da Homoeosis, como é entendido para os Oligochaeta (Gates, 1949: 134), pode ser individual, que é o caso mais comum, ou filético, como em Estherella (Gates, 1970: 1) e Brunodrilus (Righi, 1971c: 388). Com base no material que dispomos, não podemos definir o que está ocorrendo e infelizmente não conseguimos outros animais que provêm de uma região de difícil acesso. Daí preferimos eleger o novo gênero Exisdrilus pelo interesse que possa despertar e até que novos achados confirmem ou não sua validade.

Exisdrilus rarus, $\mathrm{sp} . \mathrm{n}$. (Fig. 72-77)

\section{MATERIAL}

Brasil, Amazonas : Sucunduri, em barranco junto ao igarapé Saibroso, 1 exemplar clitelado (INPAZ-91), E. Rufino col. 26/6/1975.

Comprimento total $85 \mathrm{~mm}$; diâmetro na região média do corpo $2,0 \mathrm{~mm}$; número de segmento 230. O prostômio (Fig. 72) é semicircular, separado do primeiro segmento por um par de sulcos laterais curtos e uma ligeira depressão mediana dorsal. Pigmento e poros dorsais faltam. A metade posterior e ventral dos segmentos V - IX é deprimida no espaço $b b$. A partir da região compreendida entre os segmentos LXV - LXX, a face dorsal dos animais, entre as cerdas $d d$, que era convexa, torna-se sucessivamente plana e do CLX para trás os segmentos tornam-se cada vez mais curtos e a face dorsal reentrante. As cerdas dispõemse em 4 pares de séries longitudinais regulares a partir do segmento II. Faltam as cerdas ventrais em XIX. Entre os segmentos XL - L, a relação entre as cerdas é $a a: a b: b c: c d$ : $d d=2,25: 1,00: 3,75: 1,00: 4,10$. As cerdàs são sigmóides, alongadas e com a região subapical ornamentada por pequenas cicatrizes semilunares abertas para o ápice (Fig. 74). Na regiăo mediana do corpo o comprimento das cerdas varia de $362-418 \mu \mathrm{m}$, em média $383 \mu \mathrm{m}$.

$O$ clitelo situa-se nos segmentos XIV - XXI $(=8)$. É em forma de sela, com o limite inferior pouco demarcado em ab (Fig. 73). Na face ventral de XIX situa-se o campo genital masculino como quatro espessamentos justapostos, que no conjunto tem o contorno de um 
losango. Os espessamentos laterais são mais largos e salientes, transportando no ápice os poros masculinos e prostáticos combinados, em série com as cerdas a. O par de poros femininos aparece como duas áreas claras e arredondadas na região anterior do segmento $\mathrm{XVI}$, em $a b$. Cinco pares de poros de espermatecas situam-se em papilas arredondadas e diminutas nos intersegmentos $5 / 6-9 / 10$, a meia distância entre a linha média ventral e a das cerdas a.

Os septos 5/6 - 13/14 săo espessados e os demais frágeis. Todos os septos são transversais e inserem-se nos intersegmentos correspondentes. A massa faríngea ocupa os primeiros 5 segmentos. O esôfago é simples até o segmento IX, onde se dilata em uma moela musculosa, com a forma de um cilindro largo curto (Fig. 75, M) . Um par de glândulas calcíferas situa-se látero-ventralmente ao esôfago em XI. As glândulas (GC) são cilíndricas, espessas, ocupam toda a extensão do segmento e têm cor escura, provavelmente devido ao acúmulo de sangue. O intestino (I) dilata-se bruscamente em XIV, formando uma larga câmara em XIV - XV; para trás continúa com o mesmo diâmetro, porém tem aspecto moniliforme devido às constrições intersegmentares. Tiflosole e cecos intestinais faltam.

A partir do segmento XIII encontra-se um par de holonefrídios por segmento. Em cada nefrídio reconhece-se um funil, algumas alças e um duto que penetra na parede do corpo junto a cada intersegmento, em bc. A partir de XXI cada nefrídio apresenta-se mais volumoso. Nefridióporos não foram reconhecidos. Do aparelho circulatório reconhecem-se três pares de corações partindo do vaso dorsal (VD) nos segmentos XI - XIII; os 2 últimos pares são pouco mais volumosos. Vaso subneural falta.

Um par de testículos e de funis seminais largos e iridescentes situam-se em XII, cuja cavidade está cheia de espermatozóides (ES). Dois pares de vesículas seminais (VS) encontram-se em XI e XIII. As do primeiro par são largas e finas, formadas por expansões digitiformes irregularmente lobuladas e recobrem parcialmente o esôfago e as glândulas calcíferas. As do segundo par tem aspecto mais compacto, com os lobos justapostos. O par de canais deferentes corre mais ou menos retili- nearmente sobre a parede do corpo até a região mediana do segmento XIX, onde penetra na parede do corpo junto com o duto da próstata correspondente (Fig. 76) . Em cada próstata o duto é delgado e restrito ao segmento XIX. A porção glandular longá, adelgaça-se em direção ental, terminando em ponta; atravessa o septo $19 / 20$ e situa-se, em sua maior parte, no segmento XX. Um par de ovários laminares (Fig. 75 , O) prende-se à face posterior e ventral do septo $14 / 15$. O par de pequenos funis ovulares prende-se ventral e anteriormente em 15/16. Cinco pares de espermatecas situam-se nos segmentos VI - X. As espermatecas (Fig. 75, $E_{;}$77) são tubulares, sem distinçăo entre duto e ampola e tornam-se pouco maiores no sentido antero-posterior.

\section{ACANTHODRILIDAE}

Wegeneriella divergens itapecu, subsp. $\mathrm{n}$. (Fig. $78-85$ )

MATERIAL

Brasil, Amazonas : Sucunduri (Estrada Transamazônica, trecho Humaitá-Jacareacanga, $\mathrm{Km} \mathrm{523),} \mathrm{em} \mathrm{troncos}$ podres junto a um igarapé; 4 exemplares clitelados e 1 maduro aclitelado (INPAZ-84), L. Antony, E. Rufino, E. Froehlich \& G. Righi col. 28/6/1975.

O comprimento dos animais clitelados varia de 18 - $33 \mathrm{~mm}$, em média $26 \mathrm{~mm}$. O diâmetro varia no clitelo de $1,0-1,2 \mathrm{~mm}$, em média $1,17 \mathrm{~mm}$ e na região mediana do corpo de $0,8-1,0 \mathrm{~mm}$, em média $0,9 \mathrm{~mm}$. O número de segmentos varia de $76-96$, em média 90 . O prostômio é do tipo epilobo aberto (Fig. 78) . O primeiro poro dorsal situa-se em $3 / 4$. A cor do dorso é violeta clara semelhante à do $\mathrm{n}^{\circ}$ 670 de Séguy (1936), o ventre é pálido e o clitelo marrom alaranjado como o $\mathrm{n}^{\circ} 201$.

O clitelo é anelar e ocupa os segmentos XIII - $1 / 2$ XX $(=7,5)$. O campo genital masculino, em XVII - XIX, é ligeiramente deprimido e esbranquiçado. Dois pares de papilas diminutas encontram-se na série de cerdas $a$, em $1 / 2$ XVII e $1 / 2$ XIX, transportando os poros prostáticos, unidos entre si por sulcos seminais retos e de margem plana (Fig. 79). Os poros masculinos são visíveis apenas em cortes, situando-se no interior dos sulcos semi- 

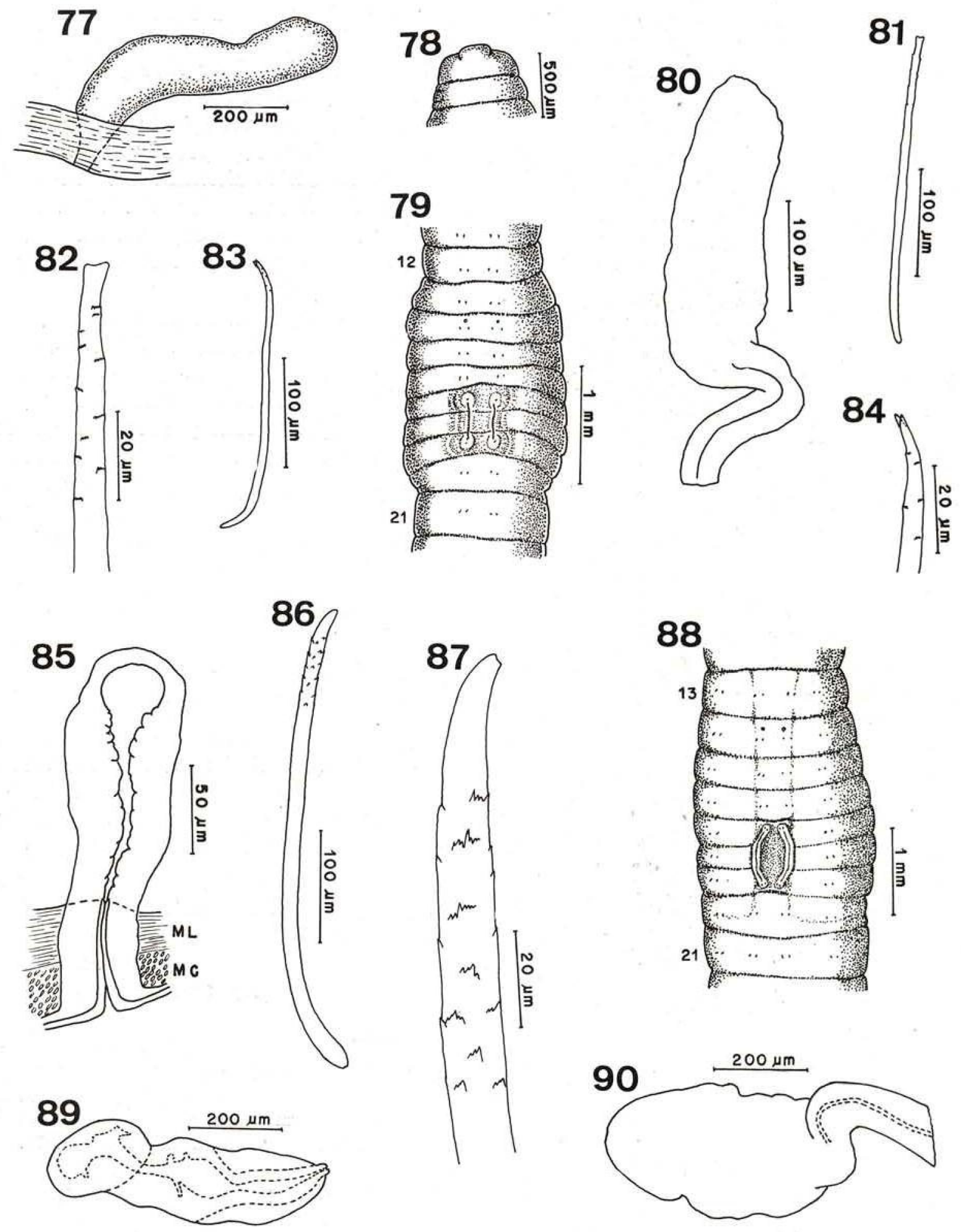

ESTAMPA VII - Exisdrilus rarus, gen, n., sp. n.: 77 - espermateca de IX. Wegeneriella divergens itapecu, subsp. n.: 78 - extremidade anterior em vista dorsal; 79 - face ventral dos segmentos; XII-XXI; 80 - próstata de XIX; 81 - cerda penial de XVII; 82 - ápice da cerda penial de XVII; 83 - cerda penial de XIX; 84 ápice da cerda penial de XIX; 85 - espermateca de IX. Wegeneriella tocaya, sp. n.: 86 - cerda penial de XVII; 87 - ápice da cerda penial de XVII; 88 - face ventral dos segmentos XIII - XXI; 89 - espermateca de VII; 90 - próstata de XIX. (MC = musculatura circular; $\mathrm{ML}=$ musculatura longitudinal. $)$ 
nais em $1 / 2 \mathrm{XVIII}$. O par de poros femininos abre-se no terço anterior de XIV, em série com $a b$. Três pares de poros de espermatecas, reconheciveis apenas em cortes, situam-se nos intersegmentos $6 / 7-9 / 10$, em linha com as cerdas ventrais.

As cerdas dispõem-se em 8 séries longitudinais regulares a partir de II. As cerdas normais têm a forma de um S alongado, com ligeiro espessamento submediano. Seu quinto apical é ornamentado por fracas cicatrizes semilunares, abertas para o ápice. O comprimento das cerdas, na região mediana do corpo, varia de $130-175 \mu \mathrm{m}$, em média $151 \mu \mathrm{m}$. Nos segmentos $X X X$ - XL obtem-se a seguinte relação entre as cerdas $a a: a b: b c: c d: d d=$ $3,6: 1,0: 4,0: 1,2: 32,4$.

O primeiro septo é o $5 / 6$ e são todos de espessura semelhante e mais ou menos transversais. Uma moela de diâmetro semelhante ao do esôfago situa-se em VII e só se reconhece em cortes devido a espessura da parede muscular. Dois pares de glândulas calcíferas lamelares, aproximadamente do mesmo tamanho, situam-se em XIV e XV. As glândulas abrem-se independentemente nas paredes latero-dorsais do esôfago. O intestino inicia-se abruptamente em XVII. Tiflosole e cecos intestinais faltam. Três pares de corações localizam-se em X - XII. A partir do segmento III há um par de holonefrídios por segmento. Funis e poros nefridiais não foram reconhecidos. O duto terminal de cada nefrídio penetra na parede do corpo junto da linha de cerdas $c d$. Os nefrídios anteriores, até o segmento XIX ou $\mathrm{XX}$ são tubulares, com algumas alças e sem bexiga. Para trás têm a forma de lâminas largas.

Dois pares de testículos e de funis seminais encontram-se livres em $\mathrm{X}$ e XI, cujas cavidades estão repletas de espermatozóides. Um par de vesículas seminais pequenas e lobuladas encontra-se dos lados do esôfago em XII. Os dois dutos seminais de cada lado correm paralelos ao lado da série de cerdas $b$, junto ao revestimento celômico. Apenas em XVIII penetram na musculatura parietal e fundem-se entre si próximo a abertura. Dois pares de próstatas tubulares restringem-se aos segmentos XVII e XIX. Em cada próstata o duto é curvo e seu comprimento equivale a aproximadamente $2 / 3$ do da porção glandular (Fig. 80 ). Associada a cada próstata há uma ou duas cerdas peniais bem diferenciadas e 1 a $3 \mathrm{em}$ formação. As cerdas peniais são do mesmo tipo, mais ou menos arqueadas (Fig. 81 e 83 ), com o quinto apical ornamentado por cicatrizes onduladas e pouco demarcadas dispostas em 4 séries alternas. O número de cicatrizes por série varia de 2 a 4 . A extremidade apical destas cerdas é espatuliforme, com os ângulos ligeiramente proeminentes (Fig. 82 e 84). O comprimento das cerdas peniais varia de $245-305 \mu \mathrm{m}$, em média $282 \mu \mathrm{m}$ e o maior diâmetro de $7,5-10 \mu \mathrm{m}$, em média $9 \mu \mathrm{m}$. Um par de ovários laminares prende-se posteroventraimente em 12/13. Ovisaco falta. Três pares de espermatecas pequenas e aproximadamente do mesmo tamanho encontram-se em VII - IX. As espermatecas são tubulares (Fig. 85), pouco mais dilatadas na porção ental e sem distinção nítida entre duto e ampola.

\section{CONSIDERAÇÕES}

Wegeneriella divergens (Cognetti, 1905) é conhecida apenas pelo material original, proveniente do Panamá, Darien, redescrito por Cognetti (1905b: 14, fig. 1-4) e recentemente por Jamieson (1974: 77, fig. 1C, 7F). W. divergens itapecu distingue-se da subespécie típica principalmente pelo tamanho e forma das cerdas peniais.

O nome da nova espécie provém da língua tupi e significa "alavanca".

\section{Wegeneriella tocaya, $\mathrm{sp} . \mathrm{n}$.} (Fig. 86-90)

\section{MATERIAL}

Brasil, Amazonas : Estrada Manaus-Itacoatiara, Km 26 (Reserva Ducke), margens do igarapé do Barro Branco, próximo a um chiqueiro, 1 exemplar clitelado (INPAZ-68), L. Antony \& G. Righi col. 23/6/1975.

O comprimento do animal é de $47 \mathrm{~mm}$ e o diâmetro préclitelar $1,53 \mathrm{~mm}$, no clitelo 1,88 $\mathrm{mm}$ e na região mediana do corpo $1,47 \mathrm{~mm}$. O número de segmentos é de 100. A cor no dorso é violeta rosada semelhante à do $n .^{\circ} 14$ de Séguy (1936), clareando para o ventre; o clitelo é branco cremoso. O prostômio é do tipo proepilobo. O primeiro poro dorsal situa-se em 
8 séries longitudinais regulares. As cerdas normais são sigmóides, com ligeiro espessamento submediano. Na região mediana do corpo (segmentos XXXV - XLV) aa : $a b: b c:$ $c d: d d=3,28: 1,00: 3,85: 1,00: 26,42$. As cerdas $a$ e $b$ de XVII e XIX são transformadas em peniais. Estas cerdas são do mesmo tipo, algo arqueadas (Fig. 86), medindo em média $400 \mu \mathrm{m}$ de comprimento. Seu quarto apical é ornamentado por espinhos irregulares e termina em ponta truncada (Fig. 87). O clitelo é em forma de sela, com o limite inferior mal definido; ocupa os segmentos XIII - 1/2 XX $(=7,5)$. Dois pares de poros prostáticos abrem-se no ápice de pequenas papilas em $1 / 2$ XVII e $1 / 2$ $\mathrm{XIX}$, em série com as cerdas a dos segmentos adjacentes, de onde emergem as cerdas peniais são côncavos em direção à linha mediana ventral; suas margens são espessas e esbranquiçadas. Em observação mais cuidadosa notase que cada sulco lembra uma linha quebrada em 17/18 e 18/19 (Fig. 88). Os poros masculinos são irreconheciveis externamente. Por observação interna verifica-se que o par de poros situa-se em $1 / 2 \mathrm{XVIII}$, no interior dos sulcos seminais. A área entre os sulcos seminais é aprofundada, bem como os intersegmentos $17 / 18$ e $18 / 19$, na região mediana ventral. Um par de poros femininos diminutos situa-se anteriormente às cerdas a em XIV . Dois pares de poros de espermatecas situamse em pequenas papilas nos intersegmentos $6 / 7$ e $7 / 8$, em série com $a b$.

Os septos $7 / 8$ - $12 / 13$ são pouco mais espessos do que os demais. A volumosa massa faríngea estende-se até o segmento VI. Moela falta. O esôfago é moniliforme de VII - XVII. Dois pares de glândulas calcíferas reniformes e de estrutura lamelar situam-se látero-dorsalmente ao esôfago em XIV e XV. Cada giândula abre-se independentemente na parede lateral do esôfago e as do segundo par são pouco maiores. A válvula esofágico-intestinal situase em XVIII. Em XX o intestino atinge o diâmetro normal que segue posteriormente. Tiflosole e cecos intestinais faltam. Não obstante à falta de moela, o tubo digestivo esta cheiq de terra e restos orgânicos. O vaso dorsal é único e pode ser seguido até VII. Três pares de volumosos corações encontram-se em X - XII. Vaso subneural falta.
Em cada segmento há um par de holonefrídios. Os nefrídios anteriores, até o segmento $X X I$, são tubulares, com numerosas alças e sem bexiga. Para trás os nefrídios são em forma de placą ovóide ou, mais raramente, arredondadas. Funis nefridiais não foram encontrados. Da porção ventral de cada nefrídio parte o longo duto terminal, que sobe entre o nefrídio e a parede do corpo e penetra na mus. culatura parietal, junto de cada intersegmento, aproximadamente a meia distância entre as cerdas $d$ e a linha média dorsal. Os nefridió. poros são irreconhecíveis externamente.

Dois pares de testículos e de funis seminais iridescentes encontram-se livres em $X$ e $\mathrm{XI}$, cujas cavidades estão repletas de espermatozóides. Vesículas seminais volumosas e de paredes tênues recobrem, como uma massa contínua, o esôfago e o vaso dorsal em IX e XII. Uma massa de celomócitos preenche a cavidade de VIII. Entre os celomócitos encontram-se algumas fases de diferenciação de espermatozóides, provavelmente provenientes do rompimento da vesícula seminal de IX durante a dissecação. A porção terminal dos canais deferentes pode ser seguida até $1 / 2$ XVIII. Dois pares de próstatas situam-se em XVII e XIX. Em cada próstata a porção glandular é mais ou menos fusiforme e pouco mais longa do que o duto que tem parede espessa (Fig. 90) . Um par de ovários e de funis ovulares situam-se em XIII. Dois pares de espermatecas aproximadamente iguais e de parede espessa encontram-se em VII e VIII. Em cada espermateca a ampola é ovóide e separada do duto por ligeira constriçăo (Fig. 89) . O comprimento total do duto é cerca de 2 vezes maior do que o diâmetro da ampola. O lúmen do duto, que é estreito na porção intraparietal, dilata-se na porção celômica. Esta porção, bem como a cavidade da ampola, é plicada e contém massas de espermatozóides.

\section{CONSIDERAÇõES}

Wegeneriella tocaya, sp. n. é bastante próxima de $W$. divergens (Cognetti, 1905), separando-se especialmente pelo seu tamanho e pelo número de espermatecas.

O nome da nova espécie provem da língua tupi, onde "tocaya" = chiqueiro. 


\section{OCTOCHAETIDAE}

\section{Dichogaster affinis (Michaelsen, 1890)}

Benhamia affinis Michaelsen, $1890: 29$, est. 4, fig. 20; 1891b: 58; 1897: 13, est. 1, fig. 17; 1900a: 234; Beddard, 1895 : 567.

Dichogaster affinis, Michaelsen, 1900b : 345; $1902: 20$; 1904: 127; 1910: 98; 1911a: 29; 1911b: 15; 1912a : 148; 1913a : 274; 1916 : 15; Cognetti, 1905b : 1905b: 38; Stephenson, 1916: 338; 1920: 258; 1923: 471; Stephenson \& Ram, 1919: 451: Cernosvitov, 1934: 50; 1935: 12; (incluindo D. sinuosus) Pickford, 1938: 95, fig. 15-16; Gates, 1939: 108; 1942a : 128; 1958: 618; 1972: 278; Graffa, 1957: 133, figs, 23-24; Righi, 1968b: 373; 1971b: 3 .

Dichogester sinuosus Stephenson, 1931b: 74, fig. 19 22; 1931c: 200 .

\section{MATERIAL}

Brasil, Amazonas: Manaus, terrenos do Instituto Nacional de Pesquisas da Amazônia, 20 exemplares clltelados e 7 maduros aclitelados (INPAZ-23), I. Ayres col. 8/11/1974; 2 exemplares clitelados (INPAZ-74), G. Righi col. 19/7/1976. Estrada Manaus-Itacoatiara, Km 26 (Reserva Ducke) em tronco podre, 1 exemplar clitetelado (INPAZ-65), E. Rufino col. 23/6/1975.

\section{Dichogaster bolaui bolaui (Michaelsen, 1891)}

Benhamia bolavi Michaelsen, 1891a: 9, figs, 1-2; 1892 : 225; (incluindo B. bolavi palmicola e B. octonephra) 1897: 15; Beddard, 1895: 565.

Benhamia malayana Horst, 1893 : 35.

Benhamia octonephra Rosa, $1895: 2 ; 1896: 137$, fig. 13; Cognetti, $1900: 9$.

Benhamia bolaví palmicola Eisen, 1896 : 132, figs. 0, 44, $51,52 K-L, 53,54 ; 1900: 311$, est. 10, fig. 74 ; Stephenson, $1916: 348$.

Benhamia bolavi pacifica Eisen, $1900: 209$, est. 10, fig. $68-73$.

Dichogaster bolaui (incluindo B. octonephra, B. b. palmicola e B. b. pacifica) + D. malayana, Michaelsen, 1900b: 340, 341; 1905: 310; 1910: 98; 1911a : 28; 1912a : 148; 1913a : 273; 1913b : 417; 1916a : 15; 1921: 22; 1922: 18; $1924: 132 ; 1927: 370$; 1928: 9; 1935a : 58; 1935b : 101; Cognetti, 1905b : 40; 1909b: 360; Stephenson, 1917: 413; 1920 : 257; (D. b. bolaui + D. b. malabaricus + D. malayana) $1923: 472,473,475$, fig. $261 ; 1924: 132$; 1931b: 64, fig. 15; (incluindo D. malayana) 1931c: 195; 1933 : 934; Cernosvitov, 1934 : 49; 1935: 12; 1941: 215; (incluindo D b. malabaricus) Pickford, 1938: 98; Gates, 1942: 129; 1958: 618; 1972: 279; (incluindo'D. b. octonephra, D. b. palmicola e D. b. decanephra) Omodeo, $1955: 209 ; 1973: 18$; (D. b. bolaui incluindo D. b. var. nec. nom. (Pickford) Righi, 1968b: 374; 1971b : 4; 1972: 151; Ljungström
\& Emiliani, 1971: 21; Ljungström, 1972: 6; Ljungström, Orellana \& Priano, 1973: 240; Ljungström, Emiliani \& Righi, 1975: 20.

D. bolaui var. nec. nom. Michaelsen, 1903: 443.

D. bolaui octonephra Cognetti, 1905a: 2; (incluindo D. b. palmicola, D. b. pacifica e D. b. var. nec. nom. Michaelsen) Cognetti, 1905b: 40, fig. 19.

D. malayana, Cognetti, 1909a: 1; Stephenson, 1931d: 276: Stephenson \& Ram, 1919: 451, fig. 9.

D. bolaui decanephra Michaelsen, 1915: 191.

D. bolaui malabaricus Stephenson, 1920: 257.

D. bolaui var, nec. nom. Pickford, 1932 : 286, fig. $2 j-1$.

\section{MATERIAL}

Brasil, Amazonas : Manaus, terrenos do Instituto Nacional de Pesquisas da Amazûnia, 2 exemplares clitelados (INPAZ-67), I. Ayres col. 28/10/1974. Estrada Manaus-Itacoatiara, $\mathrm{Km} 26$ (Reserva Ducke), margem do igarapé do Barro Branco, próximo a um chiqueiro, 2 exemplares clitelados (INPAZ-69), L. Antony \& G. Righi col. 23/6/1975; Km 30, 29 exemplares clitelados e 6 maduros aclitelados (INPAZ-61), 1. Ayres col. 5/1975.

A maioria dos nossos exemplares está bem caracterizada pelas descrições de Stephenson (1923: 472; 1931c: 195). Os exemplares INPAZ-69 diferem em alguns caracteres. Seus sulcos seminais são divergentes para trás, com a região dos poros masculinos voltadas para a linha média ventral. As espermatecas apresentam 2 divertículos em um dos exemplares e 1 e 3 no outro. Estes animais possuem ainda um par de diminutas vesículas seminais racemosas em XII, como na forma malabaricus (Stephenson, 1920: 257; 1923: 473) .

Dichogaster bolaui é uma espécie de distribuição circumundial na faixa tropical e subtropical e muito variável, daí a compiexa sinonímia. Pickford (1938: 99) considera D. rugosa (Eisen, 1895) como variedade de $D$. bolaui. Contudo, devido a diferenças na forma das cerdas peniais, preferimos manter rugosa e amphibiotica Dahl, 1957 como subespécies válidas.

\section{Dichogaster modigliani (Rosa, 1896)}

Benhamia modigliani Rosa, 1896:510, est, 1, fig. 1a-b. Benhamia papillata Eisen, 1896 : 135, figs . 43A-E, 52G-H. Benhamia papillata hawaiiensis Eisen, 1900: 212, fig. 72-81, 170-171.

Dichogaster papillata + D. p. var. hawaiiensis, Michaelsen, 1900b: 341, 342; Cognetti, 1905b: 43; 1909a : 2; Michaelsen, 1935b : 101; Gates, 1942b: 95. 
Dichogaster modigliani, Michaelsen, 1900b : 346; 1910 : 98; 1913a: 273; 1914: 214; 1921: 22; Stephenson, 1923 : 477; 1931b : 65; (incluindo D. doveri) 1931c : 198; 1933: 934; Cernosvitov, 1934 : 50; $1935: 12$; Gates, 1942a : 130; 1958: 620; 1972: 280; (incluindo B. papillata) Omodeo, 1973: 22, fig. 4A-G.

Dichogaster doveri Stephenson, 1931d : 276, fig. 6, 7a-b.

\section{MATERIAL}

Brasil, Amazonas: Manaus, terrenos do Instituto Nacional de Pesquisas da Amazônia, 3 exemplares clitelados (INPAZ-75), G. Righi col. 19/6/1975.

Espécie largamente distribuída na região tropical da Ásia e África. Na região Neotropical foi assinalada no México: Tepic (Eisen, 1896: 135); Colômbia: Puerto de los Pobres, próximo de Titiribi (Michaelsen, 1914: 214); Guiana Francesa (Cernosvitov, 1934: 50; 1935: 12); Brasil, Amazonas: Chicago na margem do Rio Japurá (Michaelsen, 1921: 22) e Manaus.

A forma do ápice das cerdas peniais de nosso material é semelhante à do observado por Eisen (1896, fig. 43E) diferindo dos figurados por Omodeo (1973, îigs. 4B-C) pela cerda menor ter o ápice ligeiramente ondulado, terminando em pequeno nóduio e não curvo de $90^{\circ}$ como apresenta Omodeo.

\section{Dichogasłer saliens (Beddard, 1892)}

Microdrilus saliens Beddard, 1892: 683, est, 46, fig. 8, 13; $1895: 506$.

Microdrilus asiaticus (laps.) Beddard, 1892: 706.

Dichogaster saliens, Eison, 1900: 226; Michaelsen, 1900b : 343; (incluindo D. crawi) 1935b: 102; 1935c: 55; 1936 : 46; Stephenson, 1923: 478; 1931b: 65; 1931c: 199, fig. 17; Gates, 1942a : 134; 1958: 620; 1972: 481; Graft, 1957: 134, fig. 25-27; Righi, 1968: 375, fig. $4-5 ; 1971 \mathrm{~b}: 4 ; 1972: 150$; Ljungström \& Emiliali, 1971: 21; Ljungström, 1972: 6; Ljungström, Orellana \& Priano, 1973: 240; Ljungström, Emiliali \& Righi, 1975: 20; Omodeo, 1973 : 25, fig. 5A-C.

Dichogaster crawi Eisen, 1900 : 228, est. 10, figs. 82 94B, 112-113; Michaelsen, 1900: 346; 1913b : 418, est. 32 , fig. $6-7 ;$ 1916b: 19; Stephenson, 1920 : 258; $1923: 474$.

\section{MATERIAL}

Brasil, Amazonas: Manaus, terrenos do Instituto Naciorial de Pesquisas da Amazônia, 10 exemplares clitelados (INPAZ-16), I. Ayres col. 8/11/1974; 2 exemplares clitelados e 1 jovem (INPAZ-73), G. Righi col. 19/6/1975. Estrada Manaus-Itacoatiara, Km 10, 9 exem- plares clitulados e 2 maduros aclitelados (INPAZ-58), E. F. Nascimento col. 8/3/1975; Km 15, 1 exemplar clitelado e 5 maduros aclitelados (INPAZ-59), E. F. Nascimento col. 4/1975: Km 26 (Reserva Ducke), 3 exemplares clitelados (INPAZ-63, 64), E. Rufino, L. Antony, E. Froehlich \& G. Righi col. 23/6/1975; Km 30, 2 exemplares clitelados (INPAZ-60), I. Ayres col. 5/1975. Regiäo do rio Cuieiras, próximo a um igarapé, 1 exemplar clitelado (INPAZ-77), I. Ayres col. 8/4/1975.

Espécie peregrina provavelmente originada da África equatorial e de vasta distribuição nos trópicos e subtrópicos. Na região Neotropical é conhecida de El Salvador: Santa Ana (Graff, 1957: 134) . Brasil, Amazonas: Manaus; Maranhão: Caxias (Righi, 1972: 150); Bahia: Itajubá e Jequié; Rio de Janeiro: Itaguai; Minas Gerais: Paraopeba (Righi, 1968: 375); Mato Grosso: (Righi, 1972: 150); São Paulo: Botucatu e Colina (Righi, 1968: 375) . Argentina: provincia de Santa Fé (Ljungströ:n \& Emiliani, 1971: 21).

Dichogaster andina evae, subsp. $\mathrm{n}$. (Fig. 91-96)

\section{MATERIAL}

Brasil, Amazonas: Rio Preto de Eva (Estrada Manaus-Caracarai, $\mathrm{Km} \mathrm{80}$ ), 17 exemplares (15 clitelados) (INPAZ-25), I. Ayres col. 13 e 27/11/1974.

O comprimento dos animais varia de $70-75 \mathrm{~mm}$ e o diâmetro préclitelar de $1,7-1,9 \mathrm{~mm}$, no clitelo de $2,3-2,5 \mathrm{~mm}$ e nas regiões mediana e posterior de $1,8-2,0 \mathrm{~mm}$. O número de segmentos é de $122-125$. O prostômio é do tipo epilobo $2 / 3 \mathrm{com}$ língua fechada. Os segmentos préclitelares são ligeiramente trianelares, os demais unianelares. Pigmento falta. Poros dorsais são visiveis a partir de $5 / 6$. O clitelo ocupa os segmentos $X I I-X X(=9)$; é aberto ventralmente em XII e XX e anelar nos demais. Os poros prostáticos são ligeiramente medianos à linha de cerdas a e abrem-se no centro de papilas arredondadas e pouco proeminentes no equador de XVII e XIX. Os sulcos seminais são ligeiramente convexos medianamente (Fig. 95). Os poros masculinos são microscópicos no equador de XVIII, no interior dos sulcos seminais. Em 3 dos 15 exemplares examinados há um sulco semilunar de origem lateral às cerdas $b$ de XVI e com a porção mais convexa atingindo o bordo anterior das papilas prostáticas de XVII. 
Em um animal o clitelo apresenta-se muito túrgido e rugoso, atingindo $3 \mathrm{~mm}$ de diâmetro; os sulcos seminais são paralelos e não se distinguem papilas ao redor dos poros prostáticos. Os poros femininos situam-se pouco anterior e medialmente às cerdas a de XIV, onde a região de implantação das cerdas ventrais é ligeiramente elevada. Os poros das espermatecas aparecem como pequenas depressões em $7 / 8$ e $8 / 9$, em série com as cerdas ventrais.

As cerdas têm distribuição lumbricina regular em todo o corpo a partir de II. As cerdas normais (Fig. 91) são sigmóides, alongadas, com um nódulo no início do terço distal. A porção externa é lisa ou, mais raramente, com algumas cicatrizes irregulares no lado côncavo. As cerdas ventrais são pouco maiores do que as laterais. Na região mediana do corpo o comprimento das cerdas ventrais varia de $262-300 \mu \mathrm{m}$, em média $280 \mu \mathrm{m}$ e das laterais de $212-300 \mu \mathrm{m}$, em média $280 \mu \mathrm{m}$ e das laterais de $212-300 \mu \mathrm{m}$, em média $245 \mu \mathrm{m}$. As cerdas $a$ e $b$ faltam em XVIII e as $b$ em XVII e $\mathrm{XIX}$. Em dois animais, na região mediana do corpo (segmentos $\mathrm{XXX}-\mathrm{XL}$ ) $a a: a b: b c: c d$ : $d d=3,10: 1,00: 3,50: 1,00: 34,20=5,00:$ $1,00: 3,75: 1,00: 31,00$.

Os septos anteriores são cônicos, aliongados e interpenetrados, tornando-se sucessivamente mais curtos até o $12 / 13$. Os demais são transversais. O primeiro septo visível é o 7/8. O esôfago anterior abre-se em um papo volumoso. Seguem-se duas moelas musculosas com a forma de cilíndros curtos e unidos intimamente. Em um exemplar a parede do papo é espessa e seu diâmetro idêntico ao das moelas, parecendo que o animal tem três moelas, como é típico de Eutrigaster (Cognetti, 1905: 36). Três pares de glândulas calcĩ̃eras situam-se em XV - XVII. As glândulas são aproximadamente do mesmo tamanho ou tornam-se ligeiramente maiores no sentido antero-posterior. Os animais não estão em condições satisfatórias para cortes, de modo que não pudemos estabelecer com precisão a relação entre as glândulas calcíferas e o esôfago posterior, bem como a exata posição das moelas, que em dissecação aparentam estar situadas em VIII e IX. O intestino inicia-se em XIX, já com o tiflosole, que é uma curta lamina dorsal. Cecos intestinais faltam. Três pares de corações situam-se em X - XII, sendo mais volumosos os do terceiro par. $\mathrm{Na}$ região mediana do corpo há 6 pares de meronefrídios segmentares, de forma mais ou menos arredondada e do mesmo tamanho.

Pares de testículos, funis seminais e volumosas massas de espermatozóides encontram-se livres em X e XI. Vesículas seminais faltam. Dois pares de próstatas tubulares encontram-se em XVII e XIX. Em cada próstata (Fig. 92) o duto é delgado e seu comprimento equivale a $1 / 5$ ou $1 / 6$ do da porção glandular. que se dobra como um S irregular, apertado e por vezes com as alças sobrepostas. Associado a cada próstata há um folículo com uma única cerda penial. Dos 12 folículos observados, apenas 2 apresentaram uma cerda de substituição. O comprimento das cerdas peniais varia de $700-725 \mu \mathrm{m}$, em média $710 \mu \mathrm{m}$ e o diâmetro basal, que é o maior, de $12-725 \mu \mathrm{m}$. As cerdas peniais são mais ou menos retilineas; a porção subapical faz uma pequena curvatura que termina em um gancho apertado (Fig. 93). Pequenas cicatrizes longitudinais, mal definidas, ocorrem irregularmente na metade apical das cerdas, porém faltam na porção subapical.

Dois ovários largos e com a margem livre sinuosa situam-se ventralmente em XIII. Em XIV há um par de volumosos ovisacos láterodorsais e o esôfago. Dois pares de espermatecas situam-se em VIII e IX; dirigem-se para trás dos lados da cadeia nervosa e devido à forma cônica dos septos ocupam o espaço de 2 - 3 segmentos externos. Em geral as espermatecas são quase retilíneas como na Fig. 94 , raramente dobradas como na Fig. 96. Em cada espermateca o longo duto abre-se em uma câmara mediana, de cuja porção basal parte um divertículo pedunculado, unilocular e cheio de espermatozóides. A câmara mediana separa-se do saco cego terminal por um pescoço longo e de parede espessa.

\section{CONSIDERAÇốES}

Pelas descrições e figuras cie Dichogaster andina Cognetti (1904: 4; 1905b: 38, fig . 13 - 15) conhecida do Equador oriental, San José, não restam dúvidas quanto a identidade específica de nosso maierial. Contudo, diferenças nas cerdas levou-nos a separar os ani- 

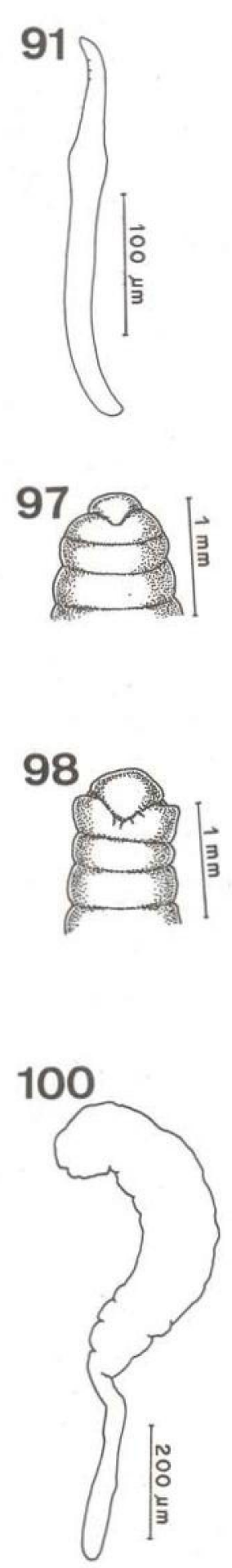
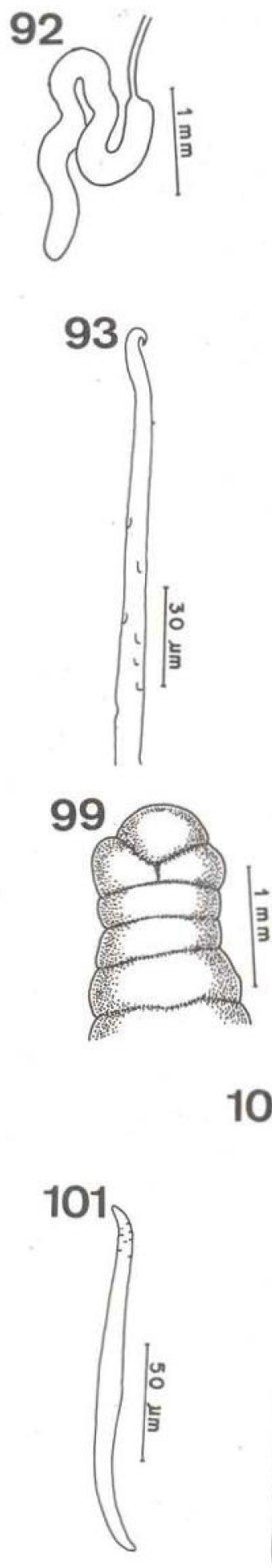

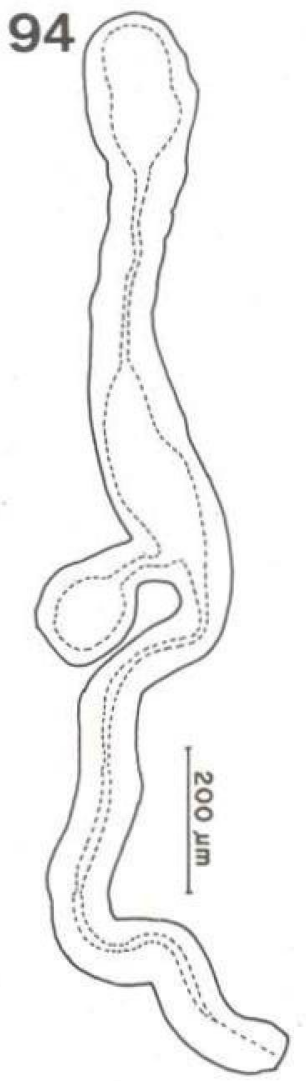

103

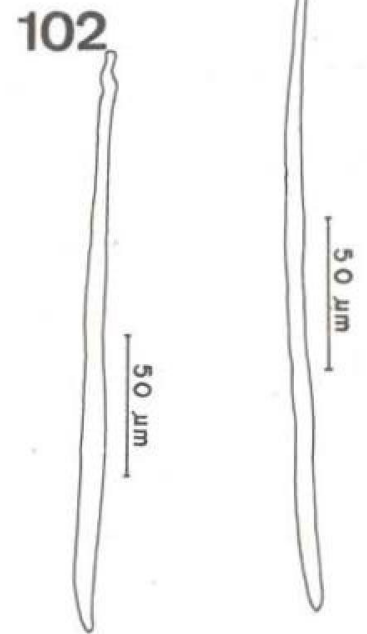

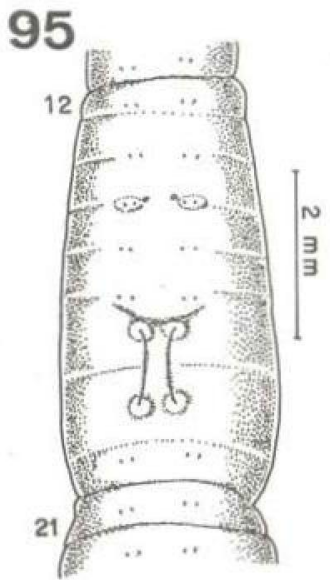

96

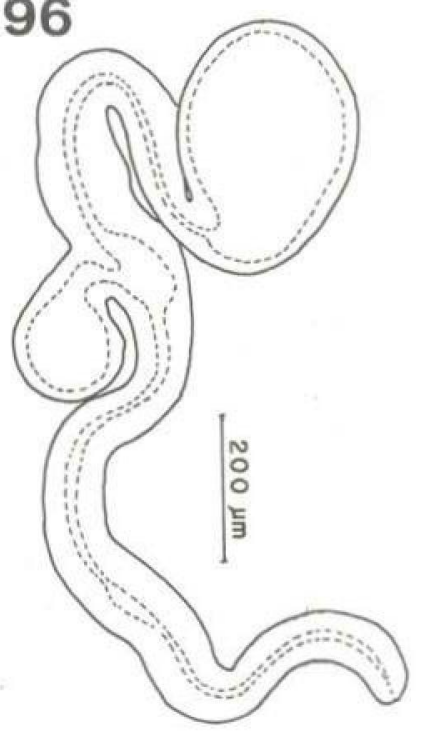

104

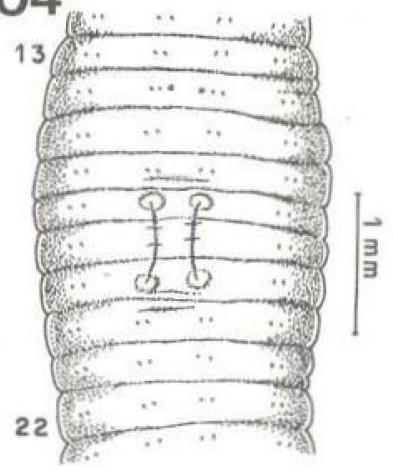

ESTAMPA VIII - Dichogaster andina evae, subsp. n.: 91 - cerda ventral mediana; 92 - próstata de XVII; 93 - ápice da cerda penial de XIX; 94 - espermateca de IX; 95 - face ventral dos segmentos XII-XXI; 96 espermateca de VIII. Dichogaster ibaia, sp. n.: 97-99 - extremidade anterior em vista dorsal; 100 - próstata de XIX: 101 - cerda ventral mediana: $102-103$ - cerda penial de XIX; 104 - face ventral dos segmentos XIII - XXII. 
mais brasileiros em uma subespéceis à parte. As duas subespécies podem ser distintas por: $D$. andina evae - cerdas normais lisas, raramente ornamentadas por cicatrizes irregulares na porção apical côncava $(D$. andina andina cerdas normais ornamentadas por poucas e pequenas incisões transversais com lábio đenteado); uma única cerda penial associada a cada poro prostático (duas cerdas peniais por poro prostático) .

Dichogaster ibaia, $\mathrm{sp} . \mathrm{n}$. (Fig. $97-111$ )

\section{MATERIAL}

Brasil, Amazonas : Estrada Manaus-Itacoatiara, Km 64 (Reserva Egler), em troncos podres com cupins, 3 exemplares clitelados e $17 \mathrm{com}$ clitelo em início de diferenciação INPAZ-76), E. F. Nascimento \& I. Ayres col. 3/6/1975.

O comprimento dos animais varia de 43 - $55 \mathrm{~mm}$ e o diâmetro na região média do corpo de 1,4 - 1,7 mm. O número de segmentos varia de 89 - 119. O prostômio é do tipo proepilobo em 8 exemplares e epilobo $1 / 2$ com língua fechada em 4 outros (Figs. 97 - 99); nos demais animais o prostômio esta intumescido e deformado. O sulco $1 / 2$ é reconhecível apenas na face dorsal. O primeiro poro dorsal localiza-se em $4 / 5$. Os animais são esbranquiçados e o clitelo laranja claro semelhante ao n. ${ }^{\circ} 190$ de Séguy (1936). O clitelo, bastante intumescido em 3 exemplares, é em forma de sela nos segmentos XIII - XX, 1/2 XXI (= $8,81 / 2$ segmentos). Seu limite inferior é junto à linha de cerdas laterais. Nos demais exemplares o clitelo, em início de desenvolvimento, é reconhecível apenas pela cor nos segmentos XIII - XIX, 1/2 XX. Dois pares de poros prostáticos situam-se no ápice de pequenas papılas arredondadas dispostas em linha com as cerdas ventrais, em XVII e XIX. Os sulcos seminais são delgados e retos ou Iigeiramente convexos em direção à linha de cerdas ventrais (Fig. 104). As margens dos sulcos são planas ou ligeiramente intumescidas. Um par de poros femininos situa-se no interior de pequenas depressões, do lado medial das cerdas $a$, em XIV. Os poros de espermatecas são irreconheciveis externamente; por dissecação vê-se que se localizam em $7 / 8$ e $8 / 9$, em série com $a$.
As cerdas dispõem-se em 8 séries regulares a partir de II. As cerdas normais são sigmóides, alongadas, sem nódulo e com o quinto apical ornamentado por entalhes semicirculares dispostos irregularmente (Fig. 101). $\mathrm{Na}$ região mediana do corpo o comprimento das cerdas laterais varia de $185-225 \mu \mathrm{m}$, em média $200 \mu \mathrm{m}$ e o das ventrais varia de $205-245 \mu \mathrm{m}$, em média $227 \mu \mathrm{m}$. As relações entre as cerdas nos segmentos XXX - XL de 5 animais enecontra-se na Tabela 6 .

TABELA 6 - Dichogaster ibaia, relações entre as cerdas nos segmentos $\mathrm{XXX}=\mathrm{XL}$ de 5 animais.

\begin{tabular}{c|ccccccccc}
\hline Exemplar & aa & $:$ & $\mathbf{a b}$ & $:$ & $\mathbf{b c}$ & $:$ & $\mathbf{c d}$ & $:$ & $\mathbf{d d}$ \\
A & 7,09 & $:$ & 1,00 & $:$ & 6,34 & $:$ & 1,06 & $:$ & 57,74 \\
B & 5,70 & $:$ & 1,00 & $:$ & 5,06 & $:$ & 1,00 & $:$ & 56,07 \\
C & 4,00 & $:$ & 1,00 & $:$ & 3,50 & $:$ & 1,00 & $:$ & 36,00 \\
D & 4,16 & $:$ & 1,00 & $:$ & 3,33 & $:$ & 1,00 & $:$ & 41,50 \\
E & 3,66 & $:$ & 1,00 & $:$ & 4,00 & $:$ & 1,00 & $:$ & 40,33 \\
Média & 4,92 & $:$ & 1,00 & $:$ & 4,44 & $:$ & 1,01 & $:$ & 46,32 \\
& & & & & & & & & \\
\hline
\end{tabular}

O primeiro septo é o $4 / 5$. Os $4 / 5-12 / 13$ são cônicos, os demais transversais. Os septos $10 / 11$ - 13/14 são pouco mais espessos do que os restantes. Duas moelas cilíndricas e fortemente musculosas situam-se em V e VI. Devido ao seu tamanho e ao da faringe, bem como à forma dos septos, as moelas ocupam o espaço correspondente aos segmentos VII - X externos. Três pares de glândulas calciferas independentes e de tamanho aproximadamente igual situam-se em XV - XVII. O intestino inicia-se em XIX já com o tiflosole mediano, dorsal. Este torna-se mais largo para trás, atingindo entre XXIII - XXVII a largura normal posterior, que equivale ao comprimento do raio do intestino. Um tiflosole lateral, esquerdo ou direito, é reconhecivel de XXVI - XXXI; sua maior largura corresponde a $1 / 5$ do tiflosole dorsal. Três pares de corações volumosos situam-se em X - XII. Em cada segmento pósclitelar há 5 - 6 pares de nefrídios, em geral 5 . Os pares de nefrídios das duas séries ventrais são os menores. Os demais são consideravelmente maiores, discoidais ou irregularmente lobados; são de igual tamanho ou os penúltimos pouco maiores. 
105

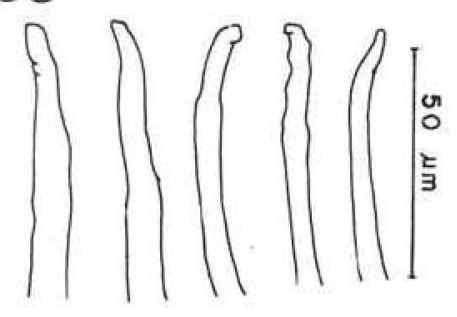

108
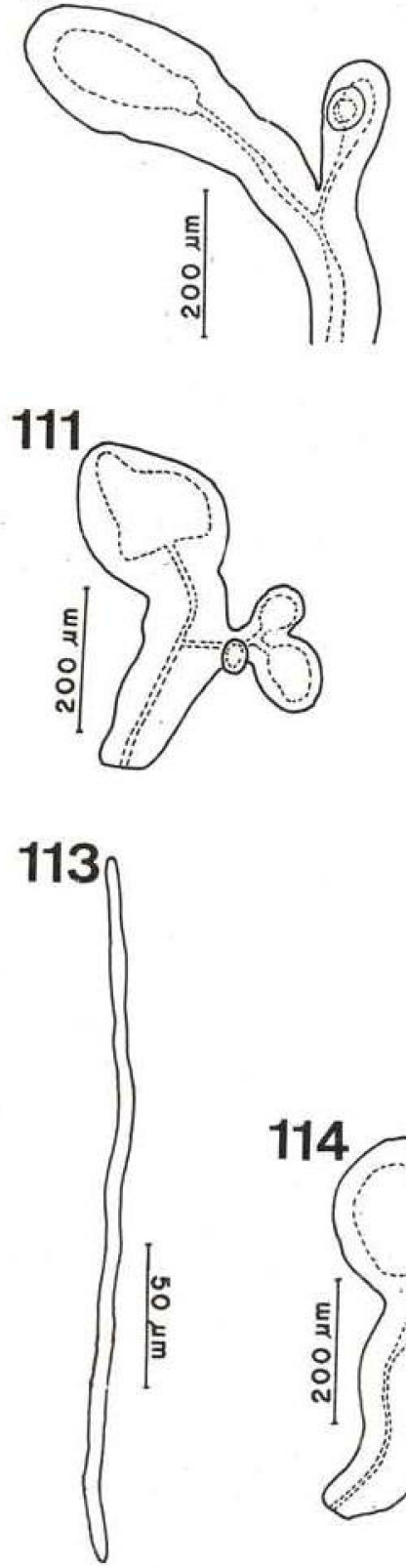
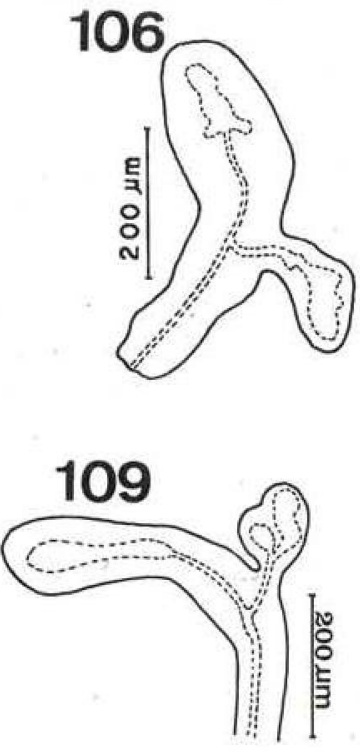

112
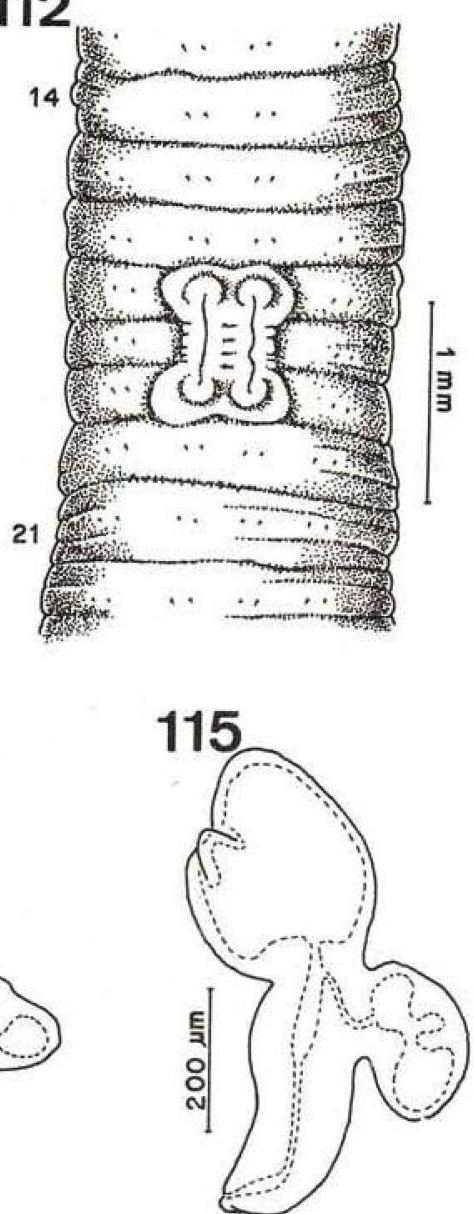

107
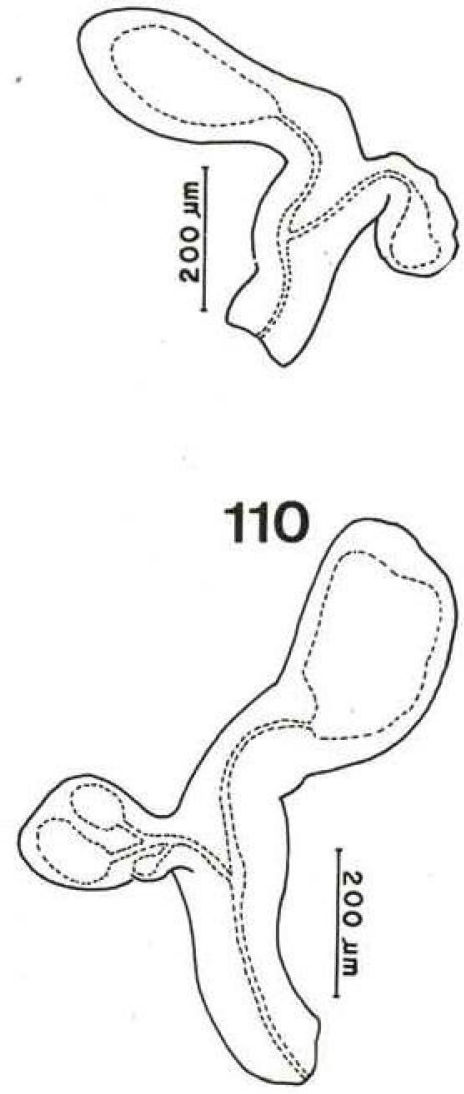

116

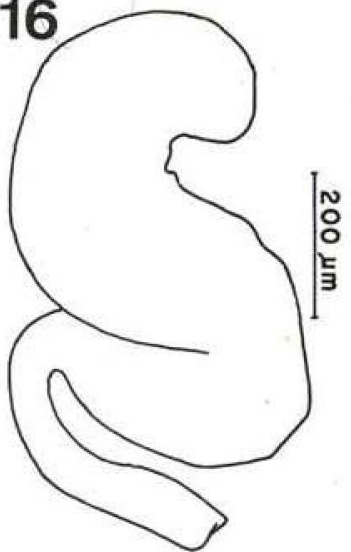

ESTAMPA IX - Dichogaster ibaia, sp. n.: 105 - ápices de cerdas peniais; $106-111$ - espermatecas. Dichogastes badajos, sp. n.: 112 - face ventral dos segmentos XIV - XXI; 113 - cerda penial de XVII; 114-115 - espermatecas de VIII e IX; 116 - próstata de XVII. 
Dois pares de testículos e de funis seminais situam-se em $X$ e XI. Vesículas seminais diminutas podem ocorrer em XI e XII. A porção terminal do par de canais deferentes é retilínea e pode ser seguida até o segmento XVIII. Dois pares de próstatas pequenas estão confinadas aos segmentos XVII e XIX. A porção glandular de cada próstata situa-se junto ao septo posterior do segmento correspondente e seu comprimento é 1,5 vezes maior do que o do duto delgado (Fig. 102). Em um animal a porção glandular das próstatas de XVII é consideravelmente maior do que a das de XIX e tem forma ondulada. Associadas a cada próstata encontram-se 2 cerdas peniais do mesmo tipo; cerdas de substituição faltam. As cerdas peniais são retas ou ligeiramente arqueadas (Fig. 102 - 103). Sua porção apical é em geral, ligeira e irregularmente ondulada e sem ornamentação, terminando em ponta chata, não espessada e sempre um pouco dobrada; quando falta a ondulação a ponta é romba. (Fig. 105). As cerdas peniais são pouco menores do que as ventrais normais. Seu comprimento varia de $180-240 \mu \mathrm{m}$, em média $217 \mu \mathrm{m}$ e o diâmetro na base varia de $6-7 \mu \mathrm{m}$.

Um par de ovários e de funis ovulares encontram-se em XIII. Um par de ovisacos presos à face posterior de $13 / 14$, ventro-lateralmente ao esôfago, foi encontrado em um único exemplar. Dois pares de espermatecas situam-se em VIII e IX. As espermatecas dos dois pares têm forma semelhante mas, as do segundo par mais volumosas. Externamente a distinção entre duto e ampola é mal definida. Da porção média e anterior do duto parte um divertículo que perfura o septo e localiza-se no segmento anterior. O divertículo pode ter 1 - 3 lóculos, em geral 2 ou 3 (Fig. 106 - 111)

\section{CONSIDERAÇõES}

Por apresentar cerdas peniais de um único tipo e sem ornamentação por espinhos ou entalhes, Dichogaster ibaia, sp. n. aproxima-se do grupo central-americano constituído por $D$. mexicana (Rosa, 1891), D. jamaicae (Eisen, 1900), D. guatemalae (Eisen, 1900), D. tristani Cognetti, 1907 e D. pitahayana Michaelsen, 1912.

Pela forma das espermatecas $D$. ibaia distingue-se de tristani, pitahayana e jamaicae, que apresentam divertículos claviformes longos. D. ibaia separa-se de mexicana e guatemalae por: 1. Poros femininos no interior de pequenas depressões do lado medial das cerdas a (D. mexicana - no ápice de papilas que se tocam pela margem interna); 2. Cerdas peniais com ligeira ondulação apical, terminando em ponta romba ou chata e algo dobrada (D. mexicana - cerdas com 6 espessamentos anelares superpostos. D. guatemalae - cerdas lisas terminando em ponta aguda); 3 . Divertículos das espermatecas com 1 - 3 lóculos, em geral 2 ou 3 (D. mexicana - divertículo curto, unilocular. D. guatemalae - divertículo plurilocular, com numerosas câmaras dispostas em roseta).

É possivel que $D$. mexicana, guatemalae e ibaia representem apenas variações de uma única espécie. Como as descrições de mexicana (Rosa, 1891 :394; Ude, 1894: 69) e de guatemalae (Eisen, 1900: 219) são muito exíguas devido à pobreza do material, a questão depende de novos achados de animais centralamericanos.

O nome da nova espécie deriva da língua tupi, onde "ybaya" = laranja

\section{Dichogaster badajos, sp. $\mathrm{n}$.}

\section{MATERIAL}

Brasil, Amazonas : regiăo do lago Badajós, em terra firme, no interior de tronco podre, 1 exemplar clitelado (INPAZ-78), M. Knoplacher col. 11/7/1975.

$\mathrm{O}$ animal mede $40 \mathrm{~mm}$ de comprimento por $2 \mathrm{~mm}$ de diâmetro na região média do corpo. Os segmentos são ligeiramente trianelares e seu número é 118. O prostômio está parcialmente invaginado, deixando visivel apenas a parte posterior, que tem forma de cunha ao terço anterior do primeiro segmento. A cor geral do dorso é marrom clara, semelhante à do $n .^{\circ} 695$ de Séguy (1936). O ventre é branco cremoso. Os poros dorsais são visíveis a partir de $5 / 6$ e persistem no clitelo.

O clitelo é em forma de sela nos segmentos XIII - XXI $(=9)$; seu limite inferior coincide com a linha de cerdas $d$. Dois pares de poros prostáticos situam-se no ápice de papilas cônicas em XVII e XIX, dispostas em série com as cerdas a. Os sulcos seminais são retos ou 
ligeiramente ondulados. A área ventral de XVII - XIX, ao redor das papilas prostáticas e dos sulcos seminais, é elevada e de aspecto glandular (Fig. 112). Os poros femininos não são visíveis. Dois pares de poros de espermatecas, pouco demarcados, abrem-se em $7 / 8$ e $8 / 9$, em série com as cerdas ventrais.

As cerdas normais são sigmóides, alongadas e sem nódulo. Sua porção apical apresenta pequenas cicatrizes longitudinais, irregulares e mais numerosas na região côncava. O comprimento das cerdas ventrais da região mediana do corpo varia de $215-250 \mu \mathrm{m}$, em média $237 \mu \mathrm{m}$. Nos segmentos $X X X-X L$, a relação entre as cerdas é $a a: a b: b c: c d: d d=$ $3,24: 1,00: 3,51: 1,00: 43,61$.

Duas moelas cilindricas, curtas e musculosas situam-se em V e VI. Três pares de glândulas calciferas independentes encontram-se em XV - XVII, sendo $1<2<3$. O intestino inicia-se em XIX mas, só atinge o diâmetro normal, posterior, em XXV. O tiflosole mediano, dorsal, é reconhecível a partir de XXI e em $\mathrm{XXV}$ atinge a largura regular posterior, que é pouco maior do que o raio do intestino. Um pequeno tiflosole lateral esquerdo encontra-se em XXIV - XXXI. Os nefrídios posclitelares dispõem-se em 5 séries longitudinais, de cada lado e tornam-se maiores no sentido ventrodorsal. Três pares de corações volumosos en. contram-se em X - XII.

Dois pares de testículos e de funis seminais situam-se nos segmentos $\mathrm{X}$ e XI, cujas cavidades estăo repletas de espermatozóides. Vesículas seminais faltam. A porção terminal do par de canais deferentes é retilínea, de diâmetro uniforme e pode ser seguida até a região mediana de XVIII, quando penetra na musculatura parietal. Dois pares de próstatas situam-se em XVII e XIX. Em cada próstata o duto é delgado e seu comprimento equivale a $3 / 5$ do da porção glândular, que é curva em S e aderida ao septo posterior dos segmentos que as contém (Fig. 116). A porção glandular do primeiro par de próstatas é quase duas vezes mais volumosa do que a do segundo par e faz saliência na cavidade de XVIII. Duas cerdas peniais estão associadas à porção terminal dos dutos prostáticos. Estas cerdas são ligeira e irregularmente onduladas, sem ornamentação e terminam em ponta romba (Fig. 113) . O comprimento das cerdas peniais varia de $223-243 \mu \mathrm{m}$ e o diâmetro basal de 4 - $5 \mu \mathrm{m}$. Um par de ovários e de funis ovulares situam-se em XIII. Um par de ovisacos sa-lienta-se da face posterior do septo 13/14, dos lados do esôfago. Dois pares de espermatecas encontram-se em VIII e IX, sendo as do segundo par mais volumosas. Em cada espermateca a ampola é arredondada ou piriforme e seu comprimento equivale à metade ou $2 / 3$ do comprimento equivale à metade ou $2 / 3$ do comprimento do duto correspondente. Um divertículo prende-se na metade ental do duto e perfura o septo anterior. Cada diverticulo apresenta 3 lóculos intercomunicantes dispostos em cadeia (Fig. $114-115$ ).

\section{CONSIDERAÇÕ̃ES}

Dichogaster badajos, sp. n. aproxima-se de D. ibaia, separando-se pela forma do poróforo masculino, das cerdas peniais e das espermatecas.

O nome da nova espécie deriva do local de coleta. 


\section{SUMMARY}

From the Brazilian Amazonia 25 species of Oligochaeta were studied for their anatomy and systematics. They are distributed onto 16 genera and 8 families as follows. Haplotaxidae: Tiguassu reginae gen. n., sp. n.; Enchytraeidae: Marionina patua, sp. n.; Alluroididae: Brinkhurstia americanus (Brinkhurst, 1964); Glossos-colecidae: Atatina gatesi, sp. n., Amazo atroaris, sp. n., A. xecatu, sp. n., Meroscolex eudoxiae, sp. n., Diachaeta juli, sp. n., Holoscolex caramuru Righi, 1975, H. nemorosus tacoa, subsp. n., Glossodrilus (G.) schubarti, sp. n.; Sparganophilidae : Areco reco, gen. n., sp. n.; Ocnerodrilidae: Eukerria guamais Righi, 1971, Haplodrilus (Hi) tagua, sp. n., Dariodrilus ferrarius, gen. n., sp. n., Exisdrilus rarus, gen. n., sp. n.; Acanthodrilidae: Wegeneriella divergens itapecu, subsp. n., Wi tocaya, sp. n.; Octochaetidae: Dichogaster affinis (Michaelsen, 1890), D. bolaui bolaui (Michaelsen, 1891), $D$. modigliani (Rosa, 1896), D. saliens (Beddard, 1892), D. andina evae, subsp. n., D. ibaia, sp. n., D. badajos, sp. n.. 
BEDDARD, F. E.

1892 - On some new species of earthworms from various parts of the world. Proc. Zool. Soc, Lond. 1892 : 66-706, est. 45-46.

1894 - A contribution to our knowledge of the Oligochaeta of tropical eastern Africa. Quart. J. micr. Sc. (N. S.) $36: 201-269$, est. 16-17.

1895 - A monograph of the Order of Oligochaeta.: XII +769 pp. 5 est. Clarendon Press, OXford.

BENHAM, W. B

1887 - Studies on earthworms. № II. Quart. J. micr. Sc. (N. S.) 27: 77-108, est. 8-9.

BRINKHURST, R. O.

1964 - A taxonomic revision of the Alluroididae (Oligochaeta). Proc. Zool. Soc. Lond. 142 (3) : 527-536, est. 1-2.

1966 - A taxonomic revision of the family Haplotaxidae (Oligochaeta). J. Zool. Lond. 150 : 29-51, est. 1-2.

1971 - Family Haplotaxidae. In Brinkhurst, R. O. \& Jamieson, B. G. M., Aquatic Oligochaet of the world : 286-303. Oliver \& Boyd, Edinburg

Cernosvitov, $\mathrm{L}$

1934 - Les Oligochètes de la Guyane Française et d'autres pays de l'Amérique du Sud. Bull. Mus. nat. Hist. Nat. Paris (2) $6: 47-59$.

1935 - Oligochaeten aus dem Tropischen SüdAmerika. Capita Zool. 6 (1) : 1-36, est, 1-6.

1938 - Oligochaeta. Mission Scientifique de I'Omo, 4: 255-318.

1941 - Oligochaeta from various parts of the world. Proc Zool. Soc. Lond. (B) 111: 197-236.

Cognetti de Martis, L.

1900 - Viaggio del Dr. A. Borelli del Mato Grosso e nel Paraguay, II. Contributo alla conoscenza degli Oligocheti Neotropicali. Boll. Mus. Torino, 15 (369) : 1-15, 1 est.

1904 - Oligocheti dell Ecuador. Boll. Mus. Torino, 19 (474): 1-18.

1905a- Oligocheti raccolti nel Darien dal Dr. E. Festa. Boll. Mus, Torino, 20 (495) : 1-7.

$1905 \mathrm{~b}-$ Gli Oligocheti della Regione Neotropicale, I. Mem. R. Accad. Sci. Torino, (2) $55: 1-72$, est. 1.

1906 - Gli Oligocheti della Regione Neotropicale, II. Mem. R. Accad. Sci. Torino, (2) $56: 147-262$, est. $1-2$.

1907 - Nuovo contributo alla conoscenza della drilofauna neotropicale. Atti R. Accad. Sc. Torino, $42: 789-800,1$ est. 1909a- Nota sulla drilofauna del Benadir. Boll. Mus. Torino, $24(600): 1-3$.

1909b- Lombrichi del Ruwenzori e dell'Uganda. II Ruwenzori, $1: 358-414$, est. 1-4.

DAHL, I, O.

1957 - Results from the Danish expedition to the French Cameroons, XXII - Oligochaeta. Bull. Inst. Franç. Afr. Noir, 19A : 1154-1172.

FISEN, G.

1896 - Pacific Coast Oligochaeta, II. Mem. Calif. Acad. Sci. 2 (4-5) : 123-198, est. 46-67.

1900 - Researches in American Oligochaeta, with special reference to those of the Pacific coast and adjacent islands. Proceed. Calif. Acad. Sci. (3) 2 : 85-276, est. 5-14.

Gattes, G. E.

1939 - Thai earthworms. J. Thailand Res. Soc, 12 : 65-114 (não visto, citado de Gates, 1972).

$1942 a$ - Notes on various peregrine earthworms. Bull. Mus. Comp. Zool. Havard, 89 : 63-144.

$1942 \mathrm{~b}$ - Check list and bibliography of North American earthworms. Amer. Midl. Natural. 27: 86-108.

1949 - Regeneration in an earthworm, Eisenia foetida (Savigny) 1826. I. Anterior regeneration. Biol. Bull. 96 (2) : 129-139.

1958 - On Burmese earthworms of the Megascolecid subfamily Octochaetidae. Ann. Mag. Nat. Hist. (13) 1 (9) : 609-624.

1959 - On a taxonomic puzzle and the classification of the earthworms. Bull. Mus. Comp. Zool. Harvard, 121 (6) : 229-261.

1966 - Contribution to a revision of the earthworm Family Ocnerodrilidae, VII-VIII. Ann. Mag. nat. Hist. (13) 9 (97-99): 45-53.

1970 - On new species in a new earthworm genus from Puerto Rico. Breviora, 356: 1-11.

1972 - Burmese earthworms. Trans. Amer. Philos. Soc. (N. S.) $62(7): 1-326$.

GIERE, $O$.

1974 - Marionina istriae, sp. n. ein mariner Enchytraeidae (Oligochaeta) aus dem Mediterranen Hygropsammal. Helgoländer Wiss. Meeresunters, $26:$ 359-369.

GRAFF, O.

1957 - Regenwürmer aus El Salvador. Senckenbergiana Biol. 38 : 115-143.

HORST, R.

1893 - Earthworms from the Malay Archipelago. In M. Weber, Zool, Ergeben. Reise Niederländisch Ost-Indien, $3: 28-77$, est. $2-4$ (não visto, citado de Michaelsen, 1900b). 
JAMIESON, B. G. M.

1962 - New species of Ocnerodrilinae (Oligochaeta) Proc. Zool. Son. Lond. 139 (4) : 607-626.

1968 - A taxonometric investigation of the Alluroididae (Oligochaeta). J. Zool. Lond. 155: 55-86.

1971 - Family Glossoscolecidae. In Brinkhurst, R. O. \& Jamieson, B. G. M., Aquatic Oligochaeta of the world: 723-837. Oliver \& Boyd, Edinburgh.

1974 - Generic type-species and other Megascolecidae (Annelida, Oligochaeta) in the Museum of Systematic Zoology, University of Turin. Boll. Muss. Zool. Univ. Torino, 8: 57-88.

LASSERE, $P$.

1964 - Note sur quelques oligochètes Enchytraeidae, presents dans les plages du basii d'Arcachon. Procès-Verbaux Soc. Linn. Bordeaux, 101: 87-91.

1966 - Oligochetes marins des côtes de France. 1. Bassin d'Arcachon: Systematique. Cah. Biol. Mar, $7: 295-317$.

LJUNGSTRóm, P. O.

1972 - Introduced earthworms of South Africa. On their taxonomy, distribution, history of introduction and on the extermination of endemic earthworms. Zool. Jb. Syst. 99: $1-81$.

Ljungstróm, P. O. \& EMiliani, F .

1971 - Contribucion al conocimiento de la ecologia y distribucion geografica de las lombrices de tierra (oligoquetos) de la Prov. de Santa Fe (Argentina). Idia, 284 : 19-32.

LJUngström, P. O.; EmIliani, F. \& Righi, G.

1975 - Notas sobre los oligoquetos (lombrices de tierra) argentinos. Rev. Assoc. Cienc. Nat. Lit. $6: 1-42$.

ljungström, P. O.; Orellana, J. A. \& Priano, L. J. J.

1973 - Influence of some edaphic factors on earthworm distribution in Santa Fe Province, Argentina. Pedobiologia, $13:$ 236-247.

Michaelsen, W.

1890 - Beschreibung der von Herrn Dr. Franz Stuhlmann im Mündungsgebiet des Sambesi gesammelten Terricolen. Anhangen I-II. Mitt. Mus. Hamburg, $7: 21-50$, est. 1-4.

1891a- Oligochaeten des Naturhistorischen Museums in Hamburg, IV. Jahrb. Mamburg. wiss. Anst. 8: 9 (não visto, citado de $\mathrm{Mi}$ chaelsen, 1877).

1891b- Beschreibung der von Herrn Dr. Fr. Stuhlmann auf Sensibar und dem gegenüberliegenden Festlande gesamelten Terricolen. Anhangen I-II. Jahrb. Hamburg, wiss. Anst. 9 (1) : 1-72, est. 1-4.

1892 - Terricolen der Berliner Zoologischen Sammlung. II. Arch. Naturg. 58 (1) : 260-261 , est. 13 .
1897 - Neue und wenig bekante afrikanische Terricolen. Mitt. Mus. Ramburg, 14 (2) : 1-71, est. 1.

1900a- Die Terricolen-Fauna Columbiens. Arch. Naturg. 66: 231-266.

1900b- Oligochaeta. Das Tierreich, 10: XXIX + $575 \mathrm{pp}$. R. Friedländer und Sohn, Berlin.

1902 - Neue Oligochaeten und neue Fundorte altbekannter. Mitt. Mus. Hamburg, 19: 1-54, est. 1.

1903 - Die Oligochäten Nordost-Afrikas. Zool. Jb. Syst. $18: 435-556$, est. 24-27.

1904 - Über eine Trinephus-Art. von Ceylon. Mitt. Mus. Hamburg, 21: 127-131.

1905 - Die Oligochäten Deutsch-Ost Arrikas. Z. wiss. Zool. 82 : 288-367, est. 19-20.

1910 - Die Oligochätenfauna der vorderindischceylonich Region. Abh. Naturw. Ver. Hamburg, 19 (5) : 1-108, est. 1.

1911a- Die Oligochaeten des inneren Ostafrikas und ihre geographischen Beziehüngen . Deutschen Zentral-Afrika Exped, 1907-1908, 2 (Zool. 1): 1-90, est. 1-2.

1911b-Die Oligochäten Westindiens. Zool. Jb. Syst. Suppl. 11: 13-12, est. 1 .

1912a- Oligochäten vom tropischen und südlich-subtropischen Afrika (1). Zoologica Sttuttgart $67: 139-170$, est. 19 .

$1912 \mathrm{~b}$ - Über einige zentralamerikanische Oligochăten Arch. Naturg. $78(9): 112-129$, est. 3.

1913a- Die Oligochäten von Neu-Caledonien und den benachbarten. Inselgruppen. In Sarasin, F. \& Roux, J., Nova Caledonia, Zoologie, 1 (3): 171-283, est. $7-8$.

1913b- The Oligochaeta of Natal and Zululand. Ann. Natal Mus. $2: 397-458$, est. 32.

1914 - Die Oligochaeten Columbias. Mem. Soc. neuchatel. Sc. Nat. 5: 202-252, est. 8.

1915 - Zentralafrikanische Oligochäten. Ergeb. Zweit Deutsch Zentral-Afrika Exped, 19101911, 1 Zool. (8) : 185-317, est. 14-18.

1916a-Die Oligochäten Westindiens, Zool. Jb. Syst. Suppl. 11: 13-31, est. 1.

1916 b - Oligochäten aus dem Naturhistorischen Reichsmuseum zu Stockholm. Ark. för Zool. 10 (9) : 1-21.

1918 - Die Lumbriciden. Zoll. Jb. Syst. 41: 1-398, est. 1-2.

1921 - Neue une wenige bekannte Oligochäten aus skandinavischen Sammlung. Ark. för Zoll. 13 (19) : 1-25, est. 1.

1922 - Oligochäten aus dem Rijks Museum van Natuurlijke Historie zu Leiden. Capita Zool. 1 (3) : 1-72.

1924 - Oligochäten von Nederländisch-Indien. Treubia Buitenzorg, 5 : 379-401.

1926 - Zur Kenntnis einheimischer und ausländischer Oligochäten, Zool. Jb. Syst. 51: 255-328. 
1927 - Oligochätenfauna Brasiliens. Abh. Senckenb Naturf. Gesel, 40 : 369-374.

1928a - Die Oligochäten Borneos. Ark. för Zool. 20 (3): $1-60$.

1928b- Oligochaeta. In Kükenthal, W. \& Krumbach, T., Handbuch der Zoologie, 2 (2 (8)) : 1-118. Walter de Gruyter \& Co. Berlin.

1935a- Die Opisthoporen Oligochäten Westindiens. Mitt Mus. Hamburg, $45: 51-64$.

$1935 \mathrm{~b}$ - Oligochaten from Christmas Island, south of Java. Ann. Mag. Nat. Hist. (10) 15 : 100-108,

1935c- Oligochäten von Belgisch Kongo, Rev. Zool. Bot. Afr. 27 (1) : 33-95.

1936 - Oligochäten von Belgisch Kongo, III. Rev. Zool. Bot. Afr. 29 (1) : 32-72, est. 3.

OMODEO, $\mathrm{P}$.

1955 - Oligochetti terricoli del Venezuela raccolti dal Dr. Marcuzzi. Mem. Mus. Civ. Stor. Nat. Verona, $4:$ 199-212.

1956 - Sistematica e distribuzione geografica degli Hormogastrinae (Oligocheti). Arch. Bot. Biog. Ital. 32: 159-177.

1958 - La réserve naturelle intégrale du mont Nimba. 1. Oligochaeta. Mem, Inst. Franç. Afr. Noire, 53 (4) : 9-109.

1973 - Oligochètes de l'Angola. Publ, cult. Co. Diam. Angola, Lisboa, 87 : 13-57.

Pantin, C, F. A.

1964 - Notes on microscopical technique for zoologists: VIII + 77 p. University Press, Cambridge.

PICKFoRd, G. E.

1932 - Oligochaeta. II. Earthworms. Discovery Reports, $4:$ 265-292.

1938 - Earthworms in Yucatan Caves. Carnegie Inst. Wash. Publ. 71-100, est. 1-3.

RIGHI, G

1968a- Ober die Oligochätengattung Eukerria. Beit. neotrop. Fauna, 5 (3) : 178-185.

1968b- Sôbre alguns Oligochaeta do Brasil. Rev. Brasil. Biol. 28 (4) : 369-382.

1969 - On some Brazilian Glossoscolecidae. Beit. neotrop. Fauna, 6 (2) : 152-162.

1970 - Sôbre o gênero Andioscolex (Oligochaeta, Glossoscolecidae). Rev. Brasil. Biol. 30' (3) : 371-376.

1971a - Sôbre a Familia Glossoscolecidae (Oligochaeta) no Brasil. Arq. Zool. S. Paulo, 20 1-96.

1971b- Sôbre alguns Oligochaeta brasileiros, Papéis Avulsos Zool. S. Paulo, 25 (1) : 1-13.

1971c- A new genus and species of Ocnerodrilinae (Oligochaeta: Acanthodrilidae) from Brazil. Zool. Anz, 186 (5/6) : 388-391.

1972 - Contribuição ao conhecimento dos Oligochaeta brasileiros. Papéis Avulsos Zool, S. Paulo, 25 (18) : 149-166.

1975 - Some Oligochaeta from the Brazilian Amazonia. Stud. neotrop. Fauna, $10: 77-95$.
Righi, G. \& AYRES, I.

1976 - Meroscolez marcusi, sp. n., Oligochaeta, Glossoscolecidae da Amazônia. Boln. Zool., Univ. S. Paulo, 1 : 257-263.

Righi, G.; Ayres, I. \& Bittencourt, E. C. R.

1976 - Glossoscolecidae (Oligochaeta) do Instituto Nacional de Pesquisas da Amazônia. Acta Amazonica, $6: 335-367$.

RosA, D.

1891 - Die exotischen Terricolen des k. k. naturhistorischen Hofmuseums. Ann. naturh. Hofmuseums, $6: 379-406$, est. 13-14.

1895 - Viaggio del dottor Alfredo Borelli nella Republica Argentina e nel Paraguay. XV. Oligocheti Terricoli, Boll. Mus. Torino, 10 (204): 1-3.

1896a - Contributo allo studio dei Terricoli Neotropicalli. Mem. R. Accad. Sc. Torino (2) : $45:$ 89-152, est. 1

$1896 \mathrm{~b}$ - I lombrichi raccolti a Sumatra da| Dott. Elio Modigliani. Ann. Mus. Sto. Nat. Genova (2) $36: 502-532$, est. 1.

SÉGUY, E.

1936 - Code universal des couleurs.: 68 pp., 55 est. Paul Lechevalier edit., Paris.

STEPHENSON, J.

1916 - On a collection of Oligochaeta belonging to the Indian Museum. Rec. Ind. Mus., 12: 299-354.

1917 - On a collection of Oligochaeta from various parts of India and further India. Rec. Ind. Mus, 13: 353-416, est. 16-18.

1920 - On a collection of Oligochaeta from lesser known parts of India and from Eastern Persia. Mem. Ind. Mus. 7: 191-261, est. 9-11.

1923 - The fauna of British India. Oligochaeta.: XXIV + $518 \mathrm{pp}$. Taylor \& Francis, London.

1924 - Oligochaeta of the Siju Cave, Garo Hills, Assan. Rec. Ind. Mus. 26 (1): 127-135.

1930 - The Oligochaeta.: XVI + $978 \mathrm{pp}$. Clarendon Press, Oxford

1931a- The Oligochaeta from Brazil and Paraguay. J. Linn. Soc. Lond. 37: 291-326, est. 17-18.

$1931 \mathrm{~b}$ - Oligochaeta from Burma, Kenya and other parts of the world. Proc, Zool, Soc. Lond. 1931: 33-92.

1931c-Description of Indian Oligochaeta. II. Rec. Ind. Mus 33 (2) : 173-202.

1931 d- Oligochaeta from the Malay Peninsula. J. Feder. Malay Stat. Mus. 16: 261-285.

1933 - Oligochaeta from Australia, North Carolina and other parts of the world. Proc. Zool. Soc. Lond. 1932 (4) : 899-941.

STEPHENSON, J. \& RAM, H.

1919 - The prostate glands of the earthworms of the Family Megascolecidae. Trans. R. Soc. Edinburg, 52 : 435-453, est. 1.

UDE, $\mathrm{H}$.

1894 - Beiträge zur Kenntnis ausländischer Regenwürmer. Z. wiss. Zool. $57: 57-75$, est. 4 .

(Aceito para publicaçăo em 2/10/77) 